\title{
Studies on the vitamin K-dependent carboxylase in bovine liver : properties, purification procedure and a possible reaction mechanism
}

Citation for published version (APA):

de Metz, M. (1982). Studies on the vitamin K-dependent carboxylase in bovine liver : properties, purification procedure and a possible reaction mechanism. [Doctoral Thesis, Maastricht University]. Rijksuniversiteit Limburg. https://doi.org/10.26481/dis.19820618mm

Document status and date:

Published: 01/01/1982

DOI:

10.26481/dis. $19820618 \mathrm{~mm}$

Document Version:

Publisher's PDF, also known as Version of record

\section{Please check the document version of this publication:}

- A submitted manuscript is the version of the article upon submission and before peer-review. There can be important differences between the submitted version and the official published version of record. People interested in the research are advised to contact the author for the final version of the publication, or visit the DOI to the publisher's website.

- The final author version and the galley proof are versions of the publication after peer review.

- The final published version features the final layout of the paper including the volume, issue and page numbers.

Link to publication

\footnotetext{
General rights rights.

- You may freely distribute the URL identifying the publication in the public portal. please follow below link for the End User Agreement:

www.umlib.nl/taverne-license

Take down policy

If you believe that this document breaches copyright please contact us at:

repository@maastrichtuniversity.nl

providing details and we will investigate your claim.
}

Copyright and moral rights for the publications made accessible in the public portal are retained by the authors and/or other copyright owners and it is a condition of accessing publications that users recognise and abide by the legal requirements associated with these

- Users may download and print one copy of any publication from the public portal for the purpose of private study or research.

- You may not further distribute the material or use it for any profit-making activity or commercial gain

If the publication is distributed under the terms of Article $25 \mathrm{fa}$ of the Dutch Copyright Act, indicated by the "Taverne" license above, 


\section{STUDIES ON THE VITAMIN K-DEPENDENT CARBOXYLASE IN BOVINE LIVER: \\ PROPERTIES, PURIFICATION PROCEDURE AND A POSSIBLE REACTION MECHANISM}

\section{PROEFSCHRIFT}

ter verkrijging van de graad van Doctor in de Geneeskunde aan de Rijksuniversiteit Limburg te Maastricht op gezag van de Rector Magnificus Prof. Dr. H.C. Hemker, hoogleraar, volgens het besluit van het College van Dekanen in het openbaar te verdedigen in de Aula van de Universiteit op vrijdag 18 juni 1982 des namiddags te 16.00 uur

door

\section{MENNO DE METZ \\ geboren te Den Haag}

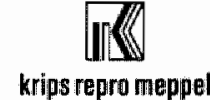


Promotor: Prof. Dr. H.C. Hermker.

Copranotor : Drs. C. Vemeer.

Peferenten : Prof. Dr. R. Azerad en Dr. H.H.W. Thijssen.

Allen, die aan het tot stand komen van dit proefschrift hebben bijgedragen, ben ik zeer erkenteljjk. In het bijzonder wil ik bedanken Mariet Molenaar voor het typewerk en de lay-out, Cees Vermeer, Berry Soute en Coen Hemker zonder wie dit onderzoek niet mogelijk zou zijn geweest, de fam. Limpens voor de verzarging van de koeien en de koeietappers, en Martin Delgado voor de tekening op de omslag. 
an mign ouders 
Chapter 1 Introduction

1.1. Vitamin $K$ and the formation of $y$-carboxyglutamic acid 6

1.2. Decarboxylation and carboxylation reactions

1.3. Introduction to this thesis

Chapter 2 comparison between vitamin K-dependent carboxylase from normal and warfarin-treated cows.

chapter 3 The preparation of an acid-soluble substrate far vitamin $\mathbb{K}$-dependent carboxylase by limited proteolysis of bovine descarboxyprothrombin.

Chapter 4 Partial purification of bovine liver vitamin $k$-dependent carboxylase by immunospecific adsorption onto antifactor $X$

chapter 5 Properties and characterization of solid phase-carboxy55 lase.

Chapter 6 Identification of phospholipid as an essential part of $6)$ bovine vitamin $k$-dependent carboxylase.

chapter 7 The inhubition of the vitamin $k$-dependent carboxylase by 79 $\mathrm{NaCN}$.

Chapter 8 Studies on the vitamin $k$-dependent carboxylation reaction: 89 carboxylation without the concurrent formation of vitamin K 2,3-epoxide.

Chapter 9 Conclusions and summary. 101

Samenvatting 105

Curriculum vitae 
CHAPTER 1

INTRODUCTION 
Vitamin $K$ and vitamin $K$ antagonists: historical background. When studying the effects of a cholesterol free diet on chicks in the 1930s, Dam noticed these animals developed a hemorrhagic diathesis. This hemostatic defect was rellated to a deficiency of the fat soluble vitamin $K(1)$, which resulted in a decrease of the prothrombin activity (2). Until the 1950s it was assumed that the only effect of a vitamin $K$ deficiency was a decreased plasma prothrombin level. Nowadays it has been accepted that vitamin $K$ functions in the biosynthesis of the clatting factors II, X, VII and IX (3), the plasma proteins $C(4), Z(5)$ and $S(6)$ and of numerous other proteins in various organs as kidney (7), bone (8), placenta (9) and in chick chorioallantoic membranes (10). The early work on vitamin $k$ has been reviewed by several autors $(11,12)$.

Since 1921 a hemorrhagic disease of cattle was known in the U.S.A. and Canada. This bleeding sympton was found to be caused by feeding improperly cured sweet clover hay. The coumarin derivates in the hay, discovered by

Fig. 1. Structures of vitamin $k_{1}$ and some vitamin $K$ antaganists.

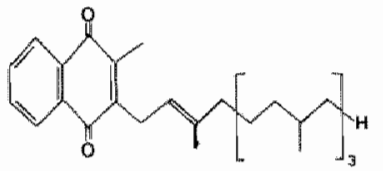

witamin $K_{1}$ or phylloquinome

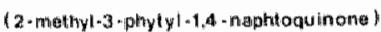

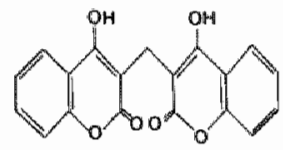

dicourrarol

( 3 - 3 methylene - bis - (4-hydroxycou that in ) )

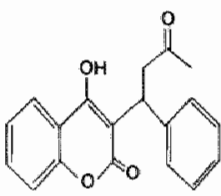

wartarin

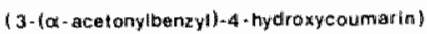

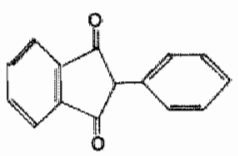

phom ind ione

(2-phenyl-1,3 - dindzonedione) 
Campbell and Link $(13,14)$, are antagonizing the action of vitamin $k$. Subsequently a large number of substituted 4 -hydroxycoumarins have been synthesized and their anticoagulant action is most helpful as a rodenticide and in the clinic for the control of thrombogenic episodes. The clinical use of these 4-hydroxycoumarins has been reviewed by 0'Reilly (15) and their structure-function relationships by Renk and Stoll (16). The anticoagulant action of 2-substituted-1,3-indanediones, which appear to act all in the same way as the coumarins, was recognized by kabat et al (17). Only the coumarin drugs are recomended for therapy as more frequent sideeffects are caused by indanediones. The structures of vitanin $k$, sone coumarin derivates and phenindione are depicted in fig. 1 .

Vitamin $k$ and precursor proteins. The first who suggested that a prothrombin precursor was involved in the vitamin $k$-dependent synthesis of prothrombin were Hemker et a1. (18). They noticed that the plasma of dicoumarol treated patients contained an abnormal form of prothrombin, which they called PIVKA II (protein induced by vitamin $\underline{k}$ absence). This finding was confirmed immunologically by Ganrot and Nilehn (19) and Josso et a1. (20). Abnormal forms of clotting factors $X$, IX and VII have also been detected in the plasma of anticoagulated humans $(21-29)$.

In the plasma of anticoagulated cows abnormal foms of prothrombin, factor $X$ and factor $I X$ have been detected $(30,31)$. Bovine abnormal prothrombin (32-34) and abnormal factor $X$ (35) have been purified. They both lack biological activity, but can be activated non-physiologically. Abnomal prothrombin can generate thrombin with the aid of trypsin (33). Echis carinatus venom (33) or staphylocoagulase $(36,37)$. After activation with Russel's viper venom abnomal factor $X$ has amidolytic activity towards Bz-11e-Glu-Gly-Arg-p-nitroaniline (35), but no actiwity in blood coagulation cam be generated from abnormal factor $x$. In the plasma of other anticoagulated species abnormal clotting factors have not been demonstrated with the exception of some abnormal prothrombin in the plasma of anticoagulated chicks (38), horses, sheep, dogs, guiney pigs, rabbits and goats (c. Vermeer, umpublished observations).

The presence of hepatic prothrombin precursors was demonstrated by Shah and Suttie (39) in the microsomal fraction of rat liver. Thrombin activity could be generated from the precursors by treatment with Echis 
Carinatus venom. The amount of hepatic precursors increased after the adninistration of warfarin or after a vitamin k-deficient diet, but it decreased rapidly after a subsequent injection of vitamin $K$. As the level of precursor fell, the amount of microsamal normal prothrombin raised until the prothrombin was demonstrated in the plasma. These data indicated that hepatic prothrombin precursors were used for the vitamin $k$-dependent synthesis of biologically active prothrombin. The first vitamin $k$-dependent in yitro system producing prothrombin from precursor prothrombin molecules was described by shah and Suttie in 1974 (40). They used the microsomal fraction of livers of vitamin $K$-deficient rats.

Several forms of abnormal prothrombin have been isolated from the liver microsomal fraction of warfarin treated rats $(41,42)$ and from cultured rat hepatoma cells (43). They are all immunologically similar to prothrombin and their molecular weights are $72000 \mathrm{~d}$. Only their isoelectric points are mutually different. The purified hepatic abnormal prothrombins have not been shown to produce prothrombin in a cell-free system.

Y-carbaxyglutamic acid: a new amino acid. Most studies concerning the $v i t a m i n k$ dependent structures in proteins are dome with bovine prothrombin and abnormal prothrombin purified from plasma. Those molecules are indistinguishable with respect to their molecular weight, their amino acid composition after acid hydrolysis and their carbohydrate composition $(33,44,45)$. The most striking difference is the ability of prothrombin to bind calcium ions, which is required for its association with phospholipids, whereas abnormal prothrombin does not bind calcium ions $(46,47,48)$. The two forms of prothrombin are also electrophoretically different in the presence of calcium ions (49). The calcium binding properties were located

Fig. 2. Sratuture of $\gamma$ - canboxygutamio aotd<smiles>NC(CC(C(=O)O)C(=O)O)C(=O)O</smiles> 
in the $\mathrm{NH}_{2}$-teminal portion of prothrombin (45) and an acidic peptide was isolated from this regüon, which could not be isolated from abnornal prothrombin (50). Stenflo, reported that a r-carboxyglutanic acid (gla) residue was present in this peptide (5:) and the presence of gla in prothrombin was confirmed by others $(52,53)$. The structure of gla is shown in fig. 2 .

Magnusson (54) reported the amino acid sequence of prothrombin and the first 10 glutamic acid residues at the $\mathbb{N}$-terminal end had an extra carboxyl group on the $\gamma-C$-atom. This -carboxylation is probably the only vitamin $K$-dependent modification in prothrombin. The discovery of gla has been reviewed extensively $(55,56)$.

After the demonstration of gla residues in bovine prothrombin numerous other proteins in plasma as well as in several organs have been reported to contain gla (57). Until now the only known physiological significance of the $\gamma$-carboxylation is related with the calcium binding properties of proteins with gla residues. This is illustrated by the enhanced activity of the vitamin $k$-dependent clotting factors in the presence of $\mathrm{Ca}^{++}$and phospholipids. Furthermore vitamin $K$-dependent proteins might be involved in the calcium mobilization of the egg shell $(10,58)$ and the deposition of calcium in bone matrix (59).

The vitamin K-dependent carboxylation. Esmon et al (60) demonstrated that the rat liver homogenates which were generating prothrombin activity (39), were also catalyzing a witamin K-dependent carboxylation reaction. Radioactive prothrombin was formed after incubation with ${ }^{14} \mathrm{C}$ labeled bicarbonate and vitamin $K$. The label was located in the racarboxyglutamic acid residues of the $\mathrm{NH}_{2}$ terminal region. Since then vitamin $k$-dependent carboxylation has been studied most extensively in microsomal liver preparations of vitamin $k$-deficient or warfarin-treated rats. The endogenous precursors present in those preparations were used as substrates for the carboxylation reaction. After the development of synthetic substrates $(61-63)$ increasingly more studies are done with those low molecular weight peptides e.g. Phe-Leu-Glu-Glu-Leu.

The vitamin $k$-dependent carboxylation reaction has been reviewed by several autors $(55-57,64,65)$ among which the extensive review by suttie (57). The main properties of the reaction are cited in table 1. 
Toble 1. Propertied of the vitamin $K$-dependent canboxylase.

Aboolute requinerentas

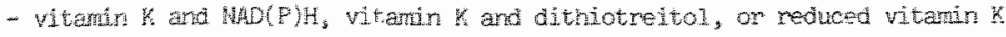

$-0$

$-\infty 2$

$-10_{2}$ accepton (endogenus substrate on a symetio peptide)

Inhisitoriss

- 2-chloro-3-phytyl-1, 4-naphtoguinone (chlore-K)

$-2,3,5,6$-tetrachloro-4-pyridinol

- courarim anticcagilarts

- sulphydry reagents

stimulators

- dituiotreitol

- pyrtdoxalphosphate

Effective vitamin $K$ activity appears to be related with 2 -methyl-1,4naphtoquinone with some substitutuents in the 3 -position $(66,64)$ and it is generally believed that the reduced form of vitamin $K$ is the active component which mediates carboxylation $(67,68)$. Also the tritium release from Phe-Leu-Glu-Glu-Leu, tritiated at the $\gamma$-carbon of each Glu residue, requires the reduced form of vitamin $k(69)$.

The role of oxygen in the carboxylation reaction, which has not been studied in any detail, will be discussed below. The active species of " $\mathrm{CO}_{2}$ " initially participating in the carboxylation reaction is postulated to be $\mathrm{CO}_{2}$ and not $\mathrm{HCO}_{3}{ }^{-}(70)$. These data are not conclusive, however, as $\mathrm{CO}_{2}$ is transported faster across the nonaqueous phase than $\mathrm{HCO}_{3}{ }^{-}$and carboxylation occurs in nonaqueous membranes $(71,72,73)$. The possible involvement of a vitamin $k$ henicarbonate in the carboxylation reaction (74) is not substantiated by experimental investigation (75).

The carboxylase activity, as measured with endogenous substrate, is almost exclusively associated with the luminal membrane surface of rough endoplasmic reticulum $(17,73)$. The smooth endoplasmic reticulum probably contains a small amount of carboxylase activity, which can only be measured with a peptide substrate (73). The carboxylase activity can be extracted 
from the membrane with several non-ionic surfactants and bile salts $(57,76,77)$. A substantial purification of those micellar solutions with carboxylating activity has not been published.

The vitamin $K$-dependent carboxylation in other tissues has not been studied as extensively as in hepatic tissues, but it seems that the requirements for carboxylation are similar in bone microsomes (8), lung microsomes (78) and the chick embryonic choriaallantoic membrane (10).

The relationship between the epoxidation of vitamin $k$ and the vitamin K-dependent carboxylation. Vitamin $k$ is partly present in the form of its 2,3-epoxide in liver (79) and vitamin $k$ "epoxidase" activity has been demonstrated in isolated microsones $(80)$. The hydroquinone form of vitamin $K$ is converted to the epoxide and the epoxide oxygen is generated by molecular oxygen (81). The epoxide can be reduced again to vitamin $k$ by the vitamin $K$ epoxide reductase $(82,83,84)$ and the reduction of vitamin $K$ quinone can be carried out by $\mathbb{N A D}(P) H$ dehydrogenase $(85,86)$, also termed DT-diaphorase (EC 1.6.99.2) and possibly by vitamin $K$ reductase (84) or vitamin $K$ epoxide reductase (87). Thus vitamin $K$ epoxide formed from vitamin $k$ hydraquinone can be converted to vitamin $k$ hydroquinone, which is called the vitamin $K$ cycle (fig. 3 ). The reduction of the epoxide is inhibited by coumarins and this seems the biologically important action of these anticoagulants $(11,55,88)$. The vitamin $k$ cycle is also active in other tissues, where vitamin K-dependent carboxylation has been demonstrated $(86)$.

Fig.3. The vitamin $K$ cycte

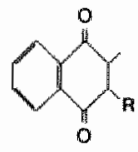

vitamin $K$

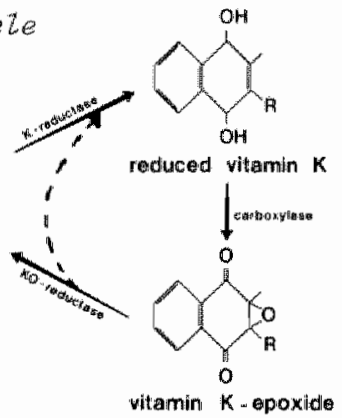


The biological function of the vitamin $K$ cycle could be the constant generation of reduced vitamin $k$ for the carboxylation reaction. In this concept the carboxylation reaction is in some way coupled to the epoxidation event and several arguments have been put forward to support this hypothesis. Many raquirements for the epoxidation and carboxylation reaction are similar $(81)$, the subcellular location of both activities is the same (73) and both activities may have a common hydroperaxide intermediate of witamin $K(90)$. Furthermore it has been demonstrated that the formation of vitamin $k$ epoxide is elevated in rat livers, which contain high levels of endogenous substrate for the carboxylation reaction (80). $\checkmark$ itamin $K$ epoxide formation could also be increased in microsomal preparations of normal rats by the addition of synthetic substrates for the carboxylase (91). The amount of epoxide formed was related to the amount of carboxylation events, but whenever the number of moles $\mathrm{CO}_{2}$ fixed per mole epoxide formed is calculated there is more epoxide formed than $\mathrm{CO}_{2}$ fixed in most cases $(91,57)$. Ry raising the $\mathrm{CO}_{2}$ concentration equal amounts of vitamin $k$ epoxide and Y-carbaxyglutamic acid can be formed (92). Thus epoxidation can take place without carboxylation. On the other hand carboxylation without expoxidation nas never been demonstrated clearly and the concept that both events are coupled in some way has generally been accepted.

\subsection{DECARBOXYLATION AND CARBOXYLATION REACTIONS.}

Decarboxylation and carboxylation: general consideration. The mechanisms of carboxylation and decarboxylation reactions will be shortly surveyed here. A plausible mechanism for the vitamin $k$-dependent carboxylation reaction is not included, but will be discussed in chapter 8 . The reaction we are dealing with is

$$
\mathrm{RH}+\mathrm{CO}_{2} \geq \mathrm{RCOOH} \quad(\text { equation } 1)
$$

The equitibrium is often closely balianced, but chelation of the carboxylated product e.g. with $\mathrm{Mg}^{++}$may shift the equilibrium in favour of the carboxyllation (93).

The enzymes catalyzing carboxylation and/or decarboxylation reactions. 
can be divided in seven groups according to their content of different coenzymes (table 2). Furthermore one biotin dependent transcarboxylation reaction is known.

Table 2. The vamious coenzymes for carboxylases and decarbangases.

\begin{tabular}{|c|c|}
\hline reaction catajyzed & coenzyme \\
\hline \multirow[t]{3}{*}{ decarboxylations } & pyridoxalphosphate \\
\hline & thiaminepyrophosphate \\
\hline & pyarvate \\
\hline & biotin \\
\hline \multirow{2}{*}{$\begin{array}{l}\text { decarboxylations and } \\
\text { carboxylations }\end{array}$} & fermedoxin \\
\hline & none \\
\hline carboxylations & vitamin \\
\hline
\end{tabular}

The reaction mechanisms of the enzyme catalyzed reactions seem not to differ from the mechanisms developped by the organic chemists and specific properties of these reactions will not be discussed. The interested reader is referred to the comprehensive book of Walsh (94).

Mechanism of decarboxylation reactions. For the decarboxylation of RCOOH both the removal of a hydrogen atom and of carbondioxide from the R-group is necessary. The removal of hydrogen is usually accomplished by having the reaction proceed in a base environment. After the removal of hydrogen and carbondioxide from a carboxylic acid a carbanion remains. It would thus be expected that this mode of decarboxylation is assisted in those organic compounds where the resultant carbanion is stabilized by electronwithdrawing groups, especially when they can exert a mesomeric as well as an inductive effect. Illustrative is the extremely ready decomposition of nitroacetic acid (equation 2).

Catalysis of decarboxylation reactions will be effected by stabilizing the carbanion. Divalent metal ions $\left(\mathrm{Cu}^{++}, \mathrm{Mn}^{++}\right)$, strong acids and primary amines are used for this purpose. The role of metal ions in catalysis is due to their electrophilic character, thus stabilizing negative charges. In 


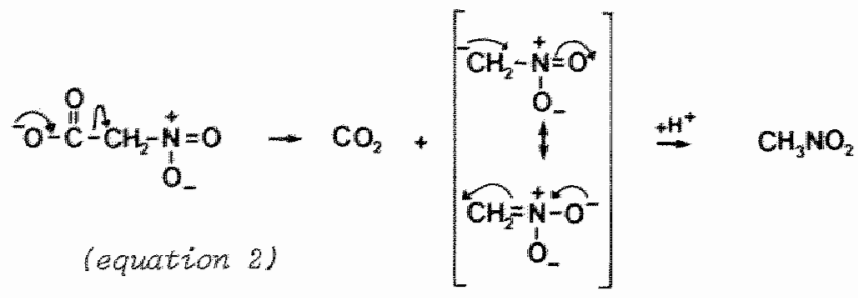

a strong acidic enwironment the substrate may be protonated and the positive charge after protonation will effectively serwe as an "electronsink" for the negative charge after the release of carbondioxide. The coenzymes pyridoxalphosphate and thiamine pyrophosfate are protonated at neutral $\mathrm{pH}$ and exert catalytic activity via this protonation.

Catalysis by primary amines is effected by the formation of a Schiff base from the condensation of the amine with a carboxyl group (equation 3 ). The Schiff base may be protonated at neutral $\mathrm{pH}$ and therefore the principle of catalysis is the same as catalysis by strong acids. An example is the decarboxylation of acetoactetate in the presence of aniline (equation 3 ).

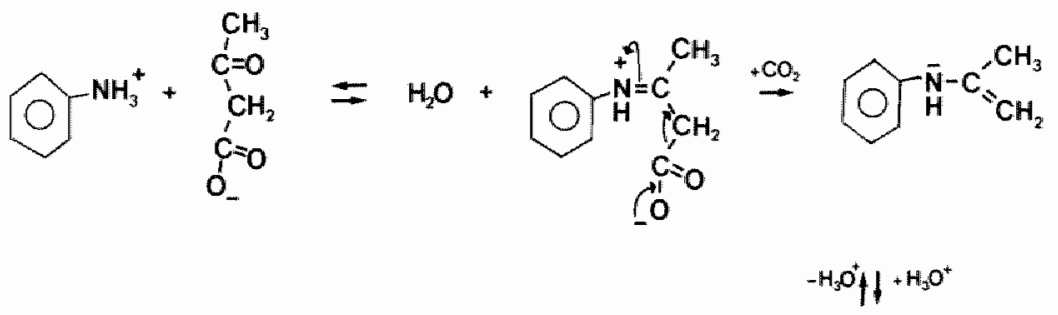

lequation 3.

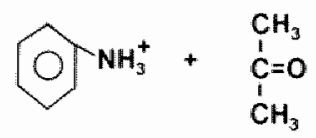

The catalysis by acetoacetate decarboxylase $(95,96)$ (E.C.4.1.1.4.) resembles the catalysis by aniline. In this case the Schiff base is formed from acetoacetate and a lysine residue of the enzyme; the electronshift during decarboxylation is as depicted in equation 3 . The coenzymes pyridoxalphosphate and pyruvate also form a schiff base with their substrates (amino acids) in order to catalyze the decarboxylation. 
Mechanism of carboxylation reactions. The carboxylation reaction as depicted in equation 1 is usualliy quite slow and therefore carboxylation reactions are generally performed under conditions where $R$ exists as a carbanion or has considerably carbanion character.

The best known carboxylation reaction is the reaction of carbondioxide with Grignard reagents (equation 4 ). The actual structure of Grignard reagents is complicated and still a matter of some dispute, but for convenience the general formula of alkylmagnesiumhalides RMgX is used. The magnesiumalogen bond is essentially ionic. The carbon-magnesium bond is covalent, but also highly polar. In other words, the organic group of Grignard reagents has considerable carbanion character and reacts with numerous inorganic compounds such as carbondioxide.

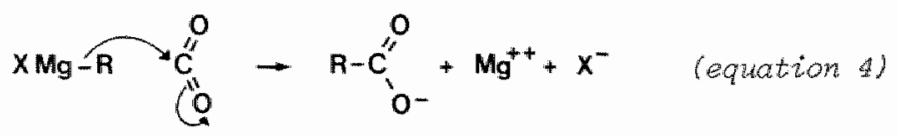

Organosodium and organolithium reagents undergo a similar carboxylation reaction as Grignard reagents.

The preparation of o-hydroxybenzoic acid (salycylic acid) from dry sodium phenoxide with carbon dioxide is a classical example of a Kolbej-Schmidt reaction. The mechanism appears to involve attack of carbon dioxide at the activated ortho position of the phenoxide ion (equation 5)

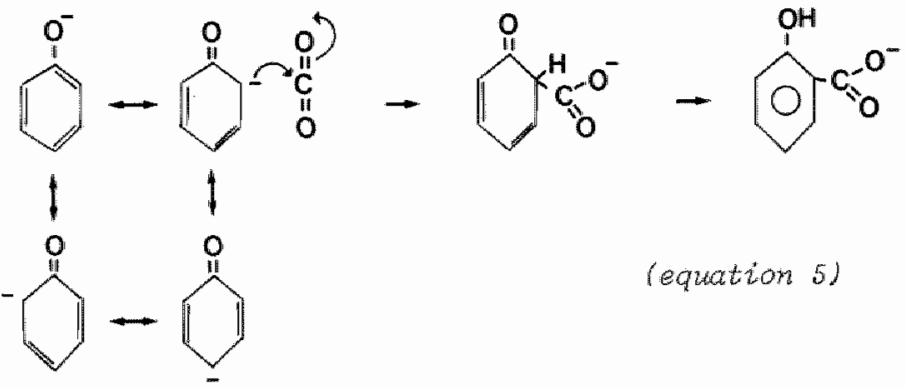

In this reaction some p-hydroxybenzoic acid is formed as well, which may be expected from the resonance structures of the phenoxide ion.

Essential for the carboxylation of Grignard reagents or for the Kolbe-Schmidt reaction is the formation of a negatively charged carbon 
atom, which can be attacked by the electrophilic carbon of carbondioxide. The carbanion can also be formed by the reduction of radicals. Although this process is not as common as the formation of carbonium ions by the oxidation of radicals (97), radicals with electron withdrawing groups e.g. a-ketoalkyl radicals are reduced relatively readily.

For the carboxylation of a radical without its prior reduction, the formation of a carbondioxide anianradical is required. After that step a radical-radical combination reaction can occur (equation 6 ).

$$
\text { R. }+\mathrm{CO}_{2}^{-} \rightarrow \mathrm{RCOO}^{-} \text {(equation } 6 \text { ) }
$$

The carbondioxide anionradical is experimentally formed during electrolytic reduction of carbon dioxide to formic acid and oxalic acid $(98,99)$ or probably via an electrontransfer from an anionradical of 1,4-dicyanobenzene and 9,10-dicyanoanthracene to carbondioxide in a polar medium (100).

The principle of the formation of a negatively charged carbon atom before addition of carbondioxide is applicable to some enzyme catalyzed carboxylations as well e.g. the carboxylation of phosphoenolpyruvate by phosphoenol pyruvatecarboxylase (E.C. 4.1.1.49) (equation 7).

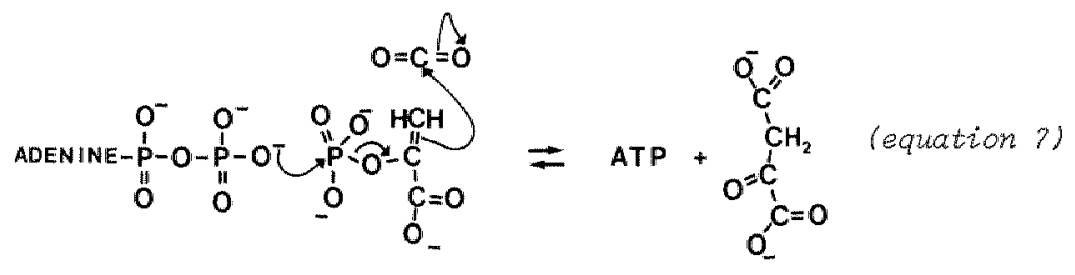

The mechanism consists of a nucleophilic attack on the phosphorylgroup of phosphoenolpyruvate, initiating an electron shift of the double bond and addition of carbon dioxide at the $\beta$-carbon of phosphoenolpyruvate.

The reaction catalyzed by biotin enzymes proceeds in two steps. The first step is the formation of the key intermediate $1-\mathrm{N}$-d-carboxybiotin and the second step is the carboxyltransfer from $\mathrm{N}$-carboxybiotin to an acceptor molecule. For the carboxyltransfer to pyruwate in the presence of $\mathrm{Mn}^{++}$, $\mathrm{Co}^{++}$or $\mathrm{Zn}^{++}$the following mechanism is proposed (equation 8) (101). 

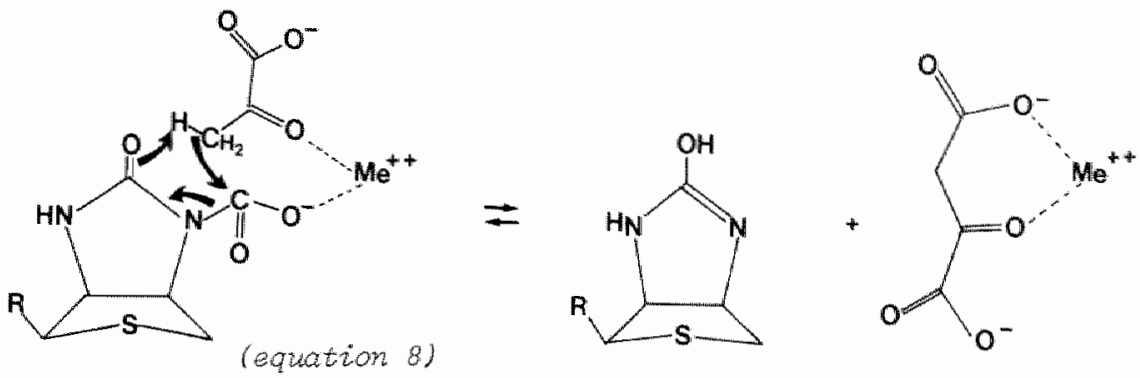

An analogous mechanism is postulated for the carboxyltransfer to coenzyme $A$ containing substrates or to water in decarboxylation reaction.

Ferredoxin-dependent carboxylation reactions are exclusively found in photosynthetic and anaerobically fermentative bacteria. The carboxylation reaction is coupled to the oxydation of reduced ferredoxin and the electrons are possibly transported from ferredoxin to the substrate by endogenous iron-sulphur chromophores (94).

\subsection{INTRODUCTION TO THIS THESIS}

Vitamin $K$ functions in the $\gamma$-carboxylation of glutamic acid residues, which takes place in various tissues and organs. The importance of these $\gamma$-carboxyglutamic acid-residues (their $\mathrm{Ca}^{++}$binding properties), is demonstrated by the process of blood coagulation. Administration of vitamin $k$ antagonists, which blocks the formation of gla e.g. in the clotting factors $I I, X, I X$ and VII has a strong anticoagulant effect. Therefore vitamin $k$ antagonists, especially the 4-hydroxycoumarin derivates, are most popular in antithrombotic therapy. As thrombosis and its results are a major cause of death in the Netherlands, the importance of controling thrombogentc eposides can hardly be exaggerated.

Until now the properties of enzymes catalyzing the vitamin $k$-dependent reaction, are not known in any detail and chemical data about the $\gamma$-carboxylation of glutamic acid residues, catalyzed by vitamin $\mathbb{K}$, are not avallable. Hence the action of vitamin $k$ and vitamin $k$ antagonists is poorly understood. In this thesis some aspects of the vitamin $K$-dependent 
carboxylase from bovine liver and a purification procedure for the enzyme are described. A mechantsm for the vitamin K-dependent carboxylation will be postulated.

\section{REFEREHCES}

1. Dam, H. (1935) Biochem. J. 29, 1273

2. Dam, H. Schonheyder, F. and Tage-Hansen, E. (1936) Biochem. J. 30, 1075

3. Davie, E.W. and Fujikawa, K. (1975) Ann.Rev.Biochem. 44, 799

4. Stenflo, J. (1976) J.Biol.Chem. 251, 355

5. Prowse, C.W. and Esnouf, M.P. (1977) Biochem.Soc.Trans. 5, 255

6. Discipio, R.G., Hermondson, H.A., Yates, S.G. and Davie, E.W. (1977) Biochem.J. 16, 698

7. Hauschka, P.V., Friedman, P.A., Traverso, H.P. and Gallop, P.H. (1976) Biochem. Biophys. Res.Commun. 71, 1207

8. Lian, J.B. and Friedman, P.A. (1978) J.Biol.Chem. 253, 6623

9. Friedman, P.A., Hauschka, P.V., Shia, M.A. and Wallace, J.K. (1979) Biochim. Biophys. Acta 583, 261

10. Tuan, R. (1979) J.Biol.Chem, 254, 1336

11. Suttie, J.W. (1978) in Fat Soluble Vitamins, Handbook of Lipid Research Vol. 2 (De Luca, H.F. ed.), Plenum Press, Mew Yark, 211.

12. Almquist, H.u. (1975). Am.J.Clin.Nutr. 28, 656

13. Campbel1, H.A. and Link, K.P. (1941) J.Biol.Chem. 138, 21

14. Link, K.P. (1959) Circulation 19, 97

15. O'Rei11y, R.A. (1976) Ann.Rev.Med. 27, 245

16. Renk, E. and Stol1, W.G. (1968) Prog.Drug.Res. 11, 226

17. Kabat, H. Stohiman, E.F. \& Smith, M.J. (1944) J. Pharmacol.Exp.Ther. 80,160

18. Hemker, H.C., Veltkamp, J.J., Hensen, H. and Loeliger, E.A. (1963). Nature 200,589

19. Ganrot, P.0. and Nilehn, J.E. (1968) Scand.J.C1 in.Lab. Invest. 22, 23

20. Josso, F., Lavergne, J.M. and Soulier, J.P. (1970) Nouv.Res.Fr. Hematol., 633 
21. Denson, K.W.E. (1971) Brit.J.Haemat. 20, 643

22. Goodnight, S.H., Feinstein, D.I. Osterud, B. and Rapaport, S.I. (1971) Blood 38,1

23. Levanon, M., Rimon, S., Shari, M., Ramot, B. and Golberg, E. (1972) Brit, J.Haematol. 23, 669

24. Brozovic, M. and Howarth, D.J. In "Prothrombin and related coagulation factors "Proceedings of a Boerhaave Course (Hemker, H.C. and Veltkamp, J.J. Eds.), Leiden University Press, Leiden, 252-263

25. Larrieu, M.S. and Meyer, 0. (1970) Lancet 11, 1085

26. Veltkamp, J.J., Muis, H., Muller, A.D., Hemker, H.C. and Loelliger, E.A. (1971) Thrombos.Diathes. Haemorrh. 25, 312

27. Lechner, K. (1972) Thrombos. Diathes. Haemorrh. 27, 19

28. Gaudernack, G., Gladhaug, R.A., Gsterud, B. and Prydz, H. (1974) Thrombos.Diathes. Haemorrh. 31, 40

29. Gaudernack, G. and Prydz, H. (1975) Thromb. Diathes. Haemorrh. 34, 455

30. Reekers, P.P.M., Lindhout, M.J., Kop-Klaassen, R.M.M. and Henker, H.C. (1973) Biochim.Biophys. Acta 317, 559

31. Lindhout, M.J., Kop-K1 aassen, B.H.M. and Henker, H.C. (1976) J.Mol.Med. 1,223

32. Malhotra, O.M. and Carter, J.R. (1971) J.Biol.Chem. 246, 2665

33. Nelsestuen, G.L. and Suttie, J.W. (1972) J.Biol.Chem. 247, 8176

34. Stenflo, J. and Ganrot, P.0. (1972) J.Biol.Chem. 247, 8160

35. Lindhout, M.J., Kop-Klaassen, B.H.M., Kop, J.M.M. and Hemker, H.C. (1978) Biochim. Biophys. Acta 533, 302

36. Josso, F., Lavergne, J.M., Govault, M., Prou-Wartelle, 0. and Soulier, J.P. (1968) Thromb.Diathes. Haemorrh. 20, 88

37. Bas, B.M., Muller, A.D. and Hemker, H.C. (1974) Biochim.Biophys. Actat 379,164

38. Carlisle, T.L., Shah, D.V., Schlegel, R. and Suttie, J.W. (1975) Proc.Soc.Exp.Biol.Med. 148, 140

39. Shah, D.V. and Suttie, J.W. (1971) Proc.Natl.Acad.Sci. U.S.A. 68, 1653

40. Shah, D.V. and Suttie, J.W. (1974) J.Biol.Chem. 250, 4744

41. Grant, G.A. and Suttie, J.W. (1974) Biochemistry 15, 5387

42. Grant, G.A. and Suttie, J.W. (1976) Arch.Biochem. Biophys. 176, 650

43. Graves, C.B. Grabau, G.G. 01 son, R.E. and Munns, T.W. (1980)

Biochemistry 19, 266 


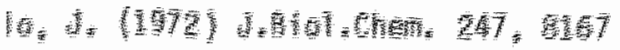

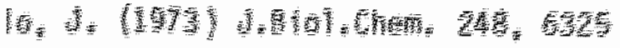

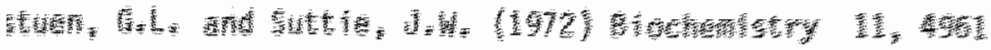

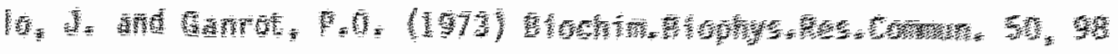

- $y=$ and

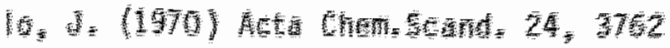

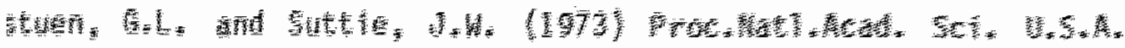
30

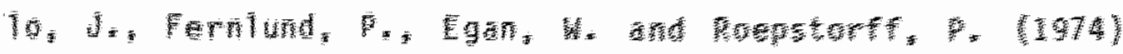

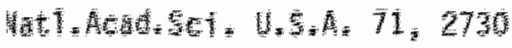

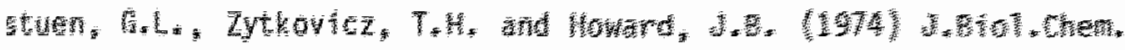
634

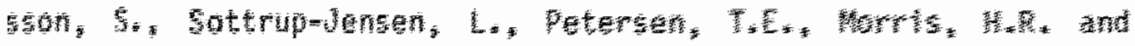
A. $(1974)$ Fegs Letz. 44, 189

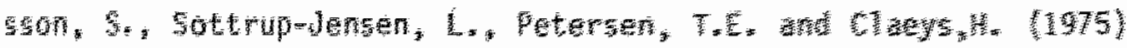

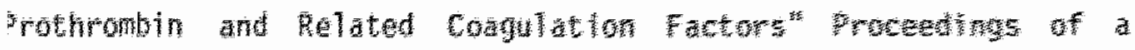

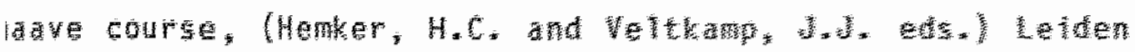
reity Press; Leiden, 25

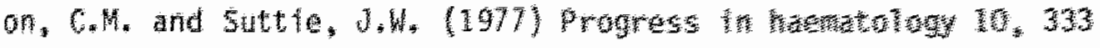

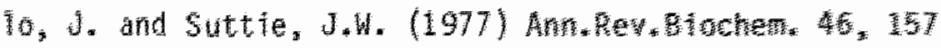

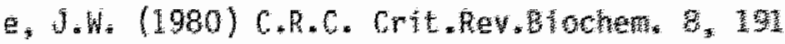

R. (1980) in "Vhtam 1 metabols

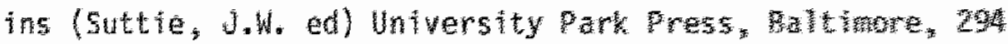

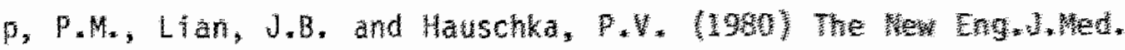
1460

운

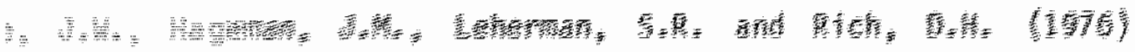

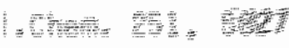

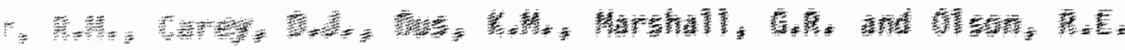

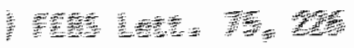

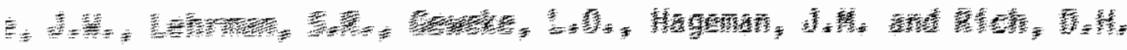

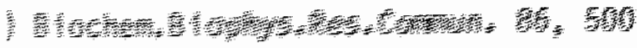

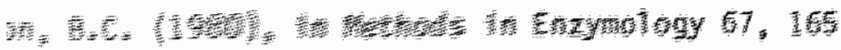

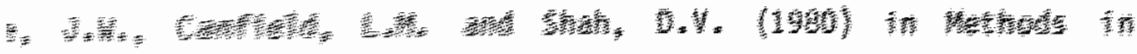

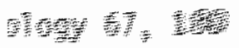


66. Mack, D.0., Wolfsenberger, M., Girardot, J.M., Miller, J. and Johnson, B.C. (1979). J.Biol.Chem. 254, 2656

67. Sadowski, J.A., Esmon, C.T. and Suttie, J.W. (1976) J.Biol.Chem. 253, 2770

68. Friedman, P.A. and Shia, M. (1976) Biochen. Biophys.Res.Commun. 70, 647

69. Friedman, P.A., Shia, M.A., Gallop, P.M. and Griep, A.E. (1979), Proc. Nat1.Acad.Sci. U.S.A. 76, 3126

70. Jones, J.P. Gardner, E.J. Cooper, T.G. and 01son, R.E. (1977) J.Biol.Chem. 252, 7738

71. Helgeland, L. (1977) Biochim. Biophys.Acta 499, 181

72. Wallin, R. and Prydz, H. (1979) Thromb. Haemostasis 41, 529

73. Carlisle, T.L. and Suttie, J.W. (1980) Biochemistry 19, 1161

74. Friedman,P.A. and Shia, M.A. (1977) Biochem. J. 163, 39

75. Chander, K.S., Gaudry, M., Marquet, A., Rikong-Adie, H., DecottigniesLemarecha1, P. and Azerad,R. (1981) Biochim. Biophys. Acta 673, 157

76. Esmon, C.T. and Suttie, J.W. (1976) J.Biol.Chem. 251, 6238

77. Mack, D.0., Suen, E.T., Girardot, J.M., Miller, J.A., Delaney, R. and Johnson, B.C. (1976) J.Biol.Chem. 251, 3269

78. Bell, R.G. (1980) Arch.Biochem. Biophys. 203, 58

79. Matschiner, J.T., Bell, R.G., Amelotti, J.M. and Knauer, T.E. (1970) Biochim. Biophys. Acta 201, 309

80. Willingham, A.K. and Matschimen, J.T. (1974) Biochem.J 140, 435

81. Sadowski, J.A., Schnoes, H.K. and Suttie, J.W. (1977) Biochemistry 16, 3856

82. Zimmerman, A. and Matschiner, J.T. (1974) Biochem.Pharmacol. 23, 1033

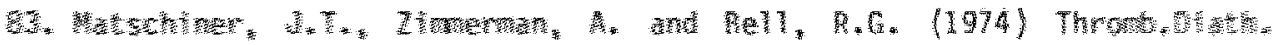

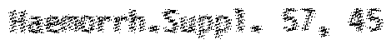

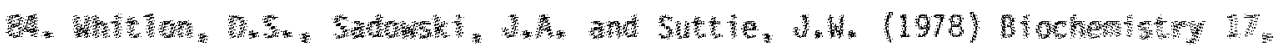

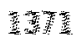

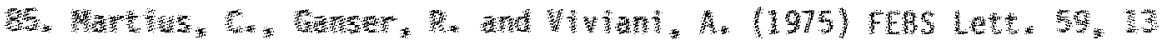

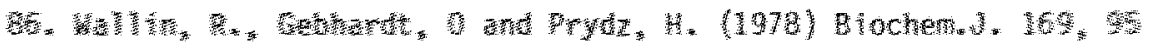

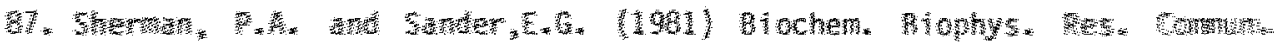

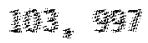

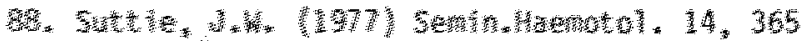

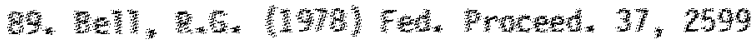

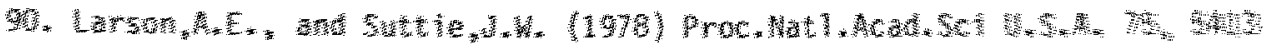


91. Suttie, J.M., Geweke, L.0., Martin, S.L. and Willingham, A.K. (1980) FEBS Lett. 109, 267

92. Larson, A.E., Friedman, P.A. and Suttie, J.W. (1981) J.Biol.Chem. 256, 11032

93. Stiles, M. and Finkbeiner, H.L. (1959) J.Am.Chem.Soc. 81, 505

94. Walsh,C. (1979) Enzymatic Reaction Mechanisms, W.H. Freeman and Comany, San Fransisco, chapter 21 and chapter 22

95. Everse, J. Barnett, R.E., Thorne, J.R. and Kaplan, H.0. (1971) Arch.Biochem. Biophys. 143, 444

96. Coulson, C.J. and Rabin, B.R. (1969) FEBS Lett. 3, 333

97. Nonhebel, D.C., Tedder, J.M. and Walton, J.C. (1979) in Radicals, Cambridge University Press, Cambridge, 138

98. Jordan, J. and Smith, P.T. (1960) Proc.Chem.Soc. 246

99. Ryu, J., Anderson, J.N. and Eyring, H.J. (1972) J.Phys.Chem. 76, 3278

100.Tazuke, S. and Kitamura, N. (1978) Nature 275, 301

101. Visser, C.M. (1977) Ph.D. Thesis, Rijksuniversiteit Groningen, Groningen 
CHAPTER 2

A COMPARISION BETWEEN VITAMTN K-DEPENDENT CARBOXYLASE FROM NORMAL AND WARFARIN-TREATED COWS.

This work has been published,

Vermeer, C., Soute, B.A.M., De Metz, M. and Hemker, H.C. (1982) Biochim. Biophys. Acta $714,361-365$ 
Detergent-solubilized microsomal preparations that are catalyzing the vitamin $k$-dependent $y$-carboxylation of glutamic acid residues in peptide and protein substrates, have been obtained from the livers of normal and warfarin-treated cows. The preparations from warfarin-treated animals contained more endogenous substrate than thase from normal cows, but otherwise the two preparations were indistinguishable. The enzymes vitamin $k$ reductase and $Y$-glutamyl carboxylase may function independentiy of each other in this system. They are, nevertheless, intimately linked in some way, so that the reduced vitamin $k$ that is produced by the former enzyme can be used immediately by the latter.

\section{INTRODUCTION}

Vitamin K-dependent carboxylase has been obtained from the livers of various animals. Administration of warfarin to the animals leads to a considerabie increase in the amount of endogenous substrate (1), and most studies dealing with the vitamin $k$-dependent carboxylase have utilized the endogenous substrate for the reaction (2). The endogenous substrate, which accumulates in cow liver after the administration of warfarin, consists mainly of precursors of clotting factor $x$, and it co-purifies with the enzyme (chapter 4). In this chapter, the properties of carboxylase preparations from normal and warfarin-treated cows have been compared in order to see if both types of carboxylase are similar, and wether conclusions obtained with the carboxylating enzyme system from nomal animals can thus also be applied to that from warfarin-treated animals and vice versa.

MATERIALS AND METHODS

Chemicals. Vitamin $k$ was obtained from Hoffmann-La Roche (Basel, Switzerland) and vitamin $K$ hydroquinome was prepared as described previously (3). Vitamin K-epoxide was prepared according to Fieser et al. 
(4). The synthetic substrate Phe-Leu-Glu-Glu-Leu was obtained from Vega Fox (Tucson, USA) and $\mathrm{NaH}^{14} \mathrm{CO}_{3}(40 \mathrm{Ci} / \mathrm{mol})$ from New England Nuclear (oreleich, GFR). Glucose axidase, Triton X-100, warfarin and dithiothreitol (DTT) were purchased by Sigma (Saint Louis, USA) Picofluor-15 by Packard Instruments (Warrenville, USA). All other chemicals were obtained fmom Merck (Darmstadt, GFR).

Preparation of carboxylase. One year ald calves were anticoagulated by the oral administration of warfarin $(10 \mathrm{mg} / \mathrm{kg}$ daily) during one week. Crude microsomes were prepared from the livers of normal and warfarin-treated cows as described earlier (3), and carboxylase was solublilized from the microsomal pellet by adding buffer containing $0.8 \mathrm{M} \mathrm{KCl}, 0.05 \mathrm{M} \mathrm{Tris-HCl}$ $(\mathrm{pH} 7.5), 0.5 \%$ Tritan $X-100$ and $30 \%$ ethylene glycol. The obtained solution with a final protein concentration of $50 \mathrm{mg} / \mathrm{m}$ ] was used for all experiments described below.

Measurement of carboxylase activity. Unless indicated otherwise, the witamin $K$-dependent incorporation of ${ }^{14} \mathrm{CO}_{2}$ was measured by incubating soluble carboxylase (5 mg protein) and $20 \mu \mathrm{Ci} \mathrm{NaH}^{14} \mathrm{CO}_{3}$ in $0.25-\mathrm{ml}$ reaction mixture containing $0.4 \mathrm{M} \mathrm{KCl}, 0.05 \mathrm{M}$ Tris-HCl (pH 7.5), $10 \mathrm{mM}$ DTT, 12\% ethylene glycol, $0.2 \%$ Triton $x-100$ and 10 mM Phe-Leu-Glu-Glu-Leu. The reaction was started by adding $0.2 \mathrm{mM}$ vitamin $K$ hydroquinone and the mixtures were incubated in parafilm-sealed tubes at $25^{\circ} \mathrm{C}$. The reaction was stopped with $2 \mathrm{ml} 10 \%$ trichloroacetic acid and the precipitates (containing the carboxylated endogenous substrate) were washed and counted in a Packard Tricarb scintillation counter using Picofluar-15 scintillation 1iquid. The trichloroacetic acid-supernatants (containing the carboxylated Phe-Leu-G1u-Glu-Leu) were degassed at $80^{\circ} \mathrm{C}$ and counted.

When the carboxylation reaction was performed in the absence of oxygen, the incubations occurred in Warburg-flasks. Before the reaction was started, $0.4 \mathrm{ml}$ of a mixture containing glucose $(0.1 \mathrm{M})$ and glucose oxidase (0.5 mg) in $0.1 \mathrm{M} \mathrm{NaCl}$ and $0.05 \mathrm{M} \mathrm{Tris-HCl,} \mathrm{pH} 7.4$ was applied in the centre well, vitamin $K$ in the side-am vessel and the other components of the reaction mixture in the outer well. The bulk of the oxygen was removed by flushing with nitrogen gas, the flasks were closed and the last traces of oxygen were removed by incubating the flasks for $1 \mathrm{~h}$ at $25^{\circ} \mathrm{C}$. After this 
period the carboxylation reaction was started by adding the vitamin $k$ hydroquinone to the reaction mixture in the outer well.

statistical analyses. The significances of the differences between the means of the results for the nomal and the warfarin-treated groups (four cows in each group) were analyzed by a one-talled Wilcoxon rank-sum test.

Determination of vitamili $K$ hydroquinone, vitamin $K$ and vitamin $k$-epoxide. The various forms of vitamin $k$ were extracted from the $1 \mathrm{ml}$ reaction mixtures, by adding $10 \mathrm{ml}$ hexane and $15 \mathrm{ml}$ isopropanol and shaking the mixtures for $5 \mathrm{~min}$. After this period, $5 \mathrm{ml}$ water was added and the upper phase was removed. The solvent was evaporated and the remaining vitamin $k$ was dissolved in $0.5 \mathrm{ml}$ methanol and analyzed by means of high-performance 1 iquid chromatography (HPLC) on a Lichrosorb 10 RP 18 column (Chrompack, $25 \times 0.46 \mathrm{~cm}$ ) in methanol. This technique was performed on a spectrophysics SP 80001 liquid chromatograph with a flow rate of $2 \mathrm{ml} / \mathrm{min}$. The three forms of vitamin $k$ were well separated when the effluent was monitored at $254 \mathrm{~nm}$ (fig 1). The area under each peak was recorded automatically and was corrected for the relative absorbance at the detection wavelength.

Fig. 1. Separation profiles of vitamin $K$ (47A s), vitamin $K$ hydroquinone (170 a) and vitamin $K$ epoxide (335 3 ).

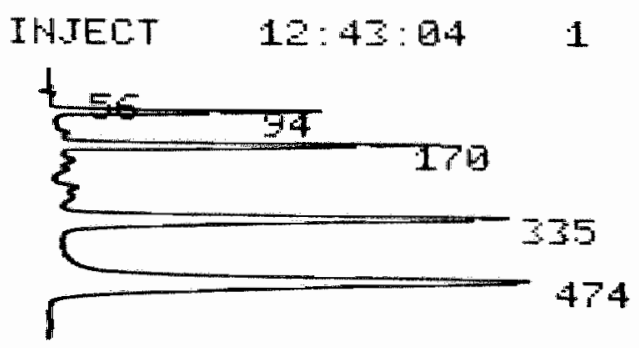

\section{END DF RUN $12: 53: 04$}

The wartious forms of vitamin $K$ ( $1 \mathrm{Hg}$ of each) were seperated and detected by their absortbance at $254 \mathrm{~mm}$. Calibration curves of each of the conponents were prepared at this wavelengte and used for the determination of the absolute arounts of the various forms of vitamin $k$. 
We compared the properties of the witamin K-dependent carboxylase present in 8 different solubilized microsomal preparations. Four preparations were obtained from normal cows and the four other preparations from cows that had received warfarin. We first investigated the optimal conditions for the carboxylation reaction. They were equal for both types of carboxylase, and were as follows: $25^{\circ} \mathrm{C}, \mathrm{pH} 7.5,0.01 \mathrm{M} \mathrm{DTT}, 0.3-0.7 \mathrm{M}$ $\mathrm{KCl}$ and $0.5 \%$ Triton $\mathrm{X}-100$. The $K_{\mathrm{n}}$ values for vitamin $K$ hydroquinone, $\mathrm{CO}_{2}$ and Phe-Leu-Glu-Glu-Leu were determined and found to be equal for both groups $(0.05,0.17$ and $11.5 \mathrm{mM}$, respectively). For technical reasons, we were unable to estimate and compare the $K_{m}$ for $0_{2}$ of the different preparations. Both types of carboxylase were completely comparable, however, in their dependece upon $\mathrm{O}_{2}$ : in the absence of axygen the incorporation of ${ }^{14} \mathrm{CO}_{2}$ amounted $109 \pm 8 \mathrm{dpm}$ per $h$ per $\mathrm{mg}$ protein and in the presence of oxygen $1472 \pm 103 \mathrm{dpm}$ (means of 8 experiments \pm S.E.).

The enzyme activities were compared by measuring the incorporation of ${ }^{14} \mathrm{CO}_{2}$ into Phe-Leu-G1u-G1u-Leu. The Phe-Leu-G1u-Glu-Leu concentration was $10 \mathrm{mM}$ because at concentrations greater than $20 \mathrm{mM}$ a marked substrate inhibition of the carboxylation was observed. With $10 \mathrm{mM}$ Phe-Leu-G1u-G1u -Leu and $0.2 \mathrm{mM}$ vitamin $K$ hydroquinone, the carboxylation rate, after a possible lag phase to be discussed later, was constant for at least $1 \mathrm{~h}$ and and it was proportional to the amount of enzyme preparation added. When we compared the enzyme activity per mg protein of the different preparations under these conditions, no significant difference between the groups was found: the carboxylation rate in the preparations obtained from normal cows was $30.0+3.2 \mathrm{dpm}$ per min per mg protein and in preparations from the four warfarin-treated animals the rate was $35.2 \pm 4.2 \mathrm{dpm}$ per min per $\mathrm{mg}$ protein.

When $\mathrm{CO}_{2}$ incorporation was determined in the absence of exogenous substrate, activity was observed only in carboxylase preparations from warfarin-treated animals (fig. 2A, C). This incorporation is interpreted as carboxylation of endogenous substrate. The final level of incorporated $\mathrm{CO}_{2}$ is proportional to the amount of the enzyme preparation added, and this level is a measure for the amount of endogenous substrate contained in this preparation. Carboxylase preparations from warfarin-treated cows contain 
significantly more endogenous substrate than the carboxylase preparations from normal cows (normal: $23.8 \pm 1.6$ dpm per mg protein, warfarin-treated: $900 \pm 72$ dpn per mo protein).

The inftial rate of incomporation can be changed by varying amount of vitamin $K$ hydroquinone. This was also found when the carboxylation of exogenous substrate was measured $(f i g .2 B, D)$. The $K_{m}$ values for vitamin $k$ hydroquinone estimated from the initial rate of $\mathrm{CO}_{2}$ incorporation in endogenous and exogenous substrate, were equal. The data in fig. 2 show that, only when endogenous substrate is present, a lag time occurs before the carboxylation of exogenous substrate starts. This is readily explained by a preferential carboxylation of the endogenous substrate.

We also investigated whether oxidized forms of vitamin $k$ could be used for the carboxylation reaction. (fig. 3)

Fig. 2. The course of the arbonglatian at warious vitamin $K$ concentrations.

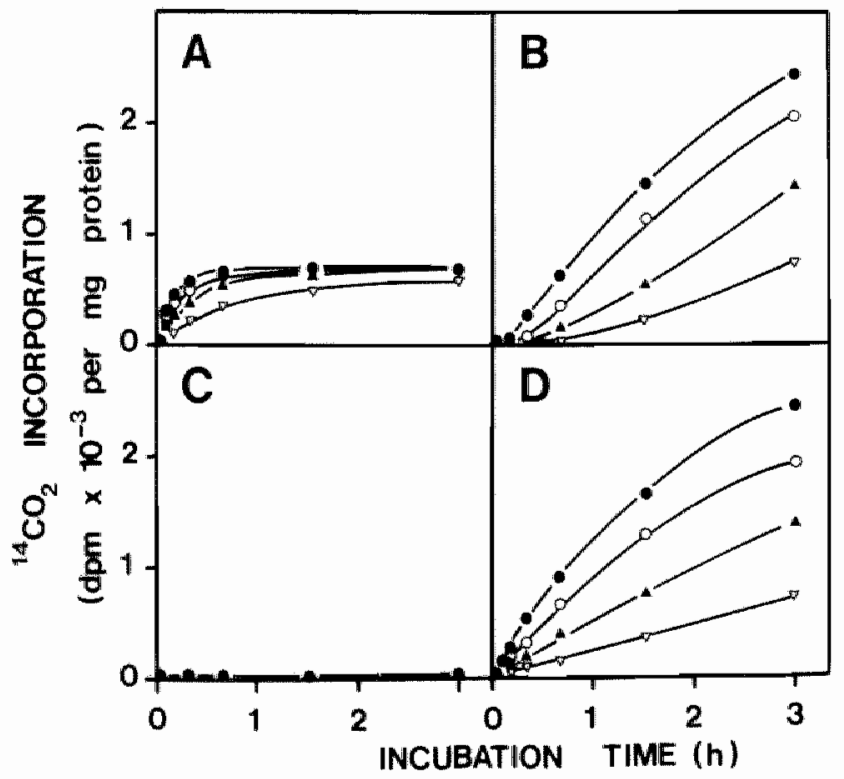

The carboxylation was performed at $0.2 \mathrm{~m}(-0), 0.1 \mathrm{~m}(0-0), 0.05 \mathrm{~m}$

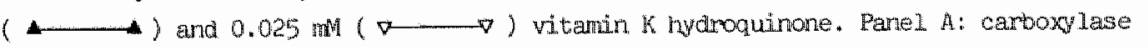
from warfarin-treated cows, endogenous substratie. Papel. B: carboxylase fron warfarintreated cows, exogenous substrate. Panel C: carboxylase from normal cows, endogenous substrate. Panel D: carboxylas from nomral cows, exogenous substrate. 
As shown in fig. 3, both endogenous and exogenous substrates can be carboxylated in the presence of DTT, when vitamin $K$ or witamin $K$ epoxide were used instead of witamin $K$ hydroquinone. This carboxylation was completely blocked by $20 \mu \mathrm{M}$ warfarin. In the rat, this level of warfarin is known to strongly inhibit the reductase (2). At equal concentrations of the coenzymes, the oxidized forms lead to lower carboxylation rates than that resulting from the reduced form. This indicates that the reduction step is rate-limiting. When carboxylase preparations from nomal cows (which do not contain endogenous substrate) are preincubated with oxidized forms of vitamin $K$ and DTT, no carboxylation can occur because of the lack of substrate, and a pool of reduced vitamin $k$ is formed, and this was demonstrated directly. Preincubated reaction mixtures were extracted with

Fig. 3. The effect of warious forms of vitamin $K$ an oamoxylase from wargarin-treated cows.

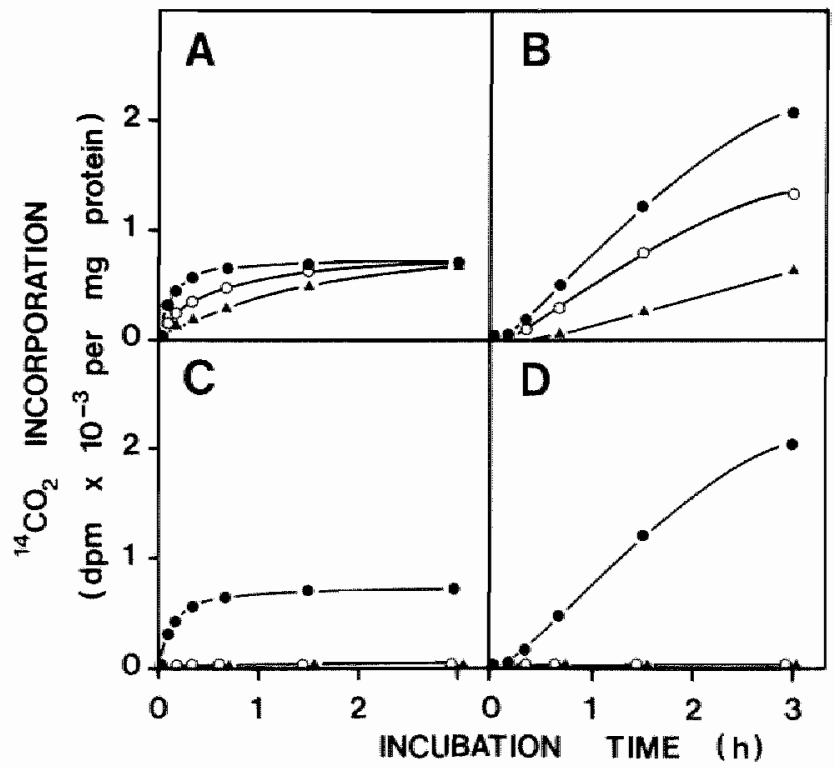

The carboxylation was performed at 0.4 m vitamin $K$ hydroguinone

vitamin $K(0$ - O ) or vitamin $K$ apoxide ( - Panel A: endogenous substrat Panel B: expgenous substrate. Panel C:mdogenous substrate plus 20 w warfarin. Panel D: exogenous substrate plus 20 wh warfarin. 
isoproponal/hexane and the extracts were analyzed for their vitamin $k$ hydroquinone content using HPLC. After $1 \mathrm{~h}$ in the presence of vitamin $K, 21$ nmol vitamin $K$ hydroquinone had been formed in the $1-m i$ reaction mixtures. Under similar conditions, vitamin $k$ epoxide was partly reduced to 14 nmo 1 vitamin $K$ and 5 nmol vitamin $K$ hydroquinone per ml reaction mixture after 1 $h$ at $25^{\circ} \mathrm{C}$. When, after this preincubation period, the carboxylation reaction was started by addition of Phe-Leu-Giu-Glu-Leu, the carboxylation reaction proceeded at the maximal rate for all three forms of vitamin $k$ (fig. 4).

Fig. 4. The effect of various forme of vitumin $R$ on carboxylase from normal cows.

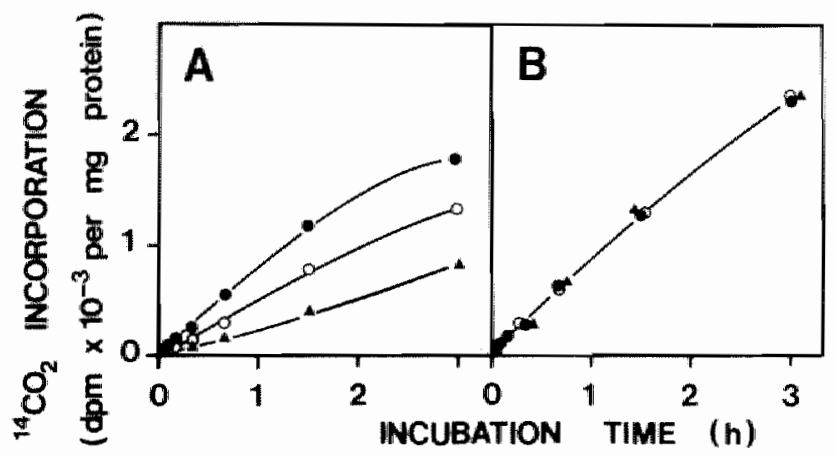

The carboxylation was performed at $0.4 \mathrm{~m}$ witamin $\mathrm{K}$ hydroquinone vitamin $\mathrm{K}(\mathrm{O} \longrightarrow)$ or vitamin $\mathrm{K}$ epoxide (- Panel $\mathrm{A}$ : without preincubation. Fanel $\mathrm{B}$ : after $1 \mathrm{~h}$ preincubation at $25^{\circ} \mathrm{C}$ in the absence of Phe-Leu-GluGlu-ieu and ${ }^{14} \mathrm{CO}_{2}$.

Drscussion

Upon comparison of the properties of the vitamin $k$-dependent carboxylase in microsomal preparations of normal and warfarin treated cows, it can be concluded that the only demonstrable difference is in the amount of endogenous substrate present. The reasons are: 1 . The optimal reaction 
conditions for both types of preparation were equal; 2. The $k_{m}$ values for witamin $K$ hydroquinone, $\mathrm{CO}_{2}$ and exogenous substrate were equal, and both enzyme systems were similarly dependent of $0_{2} ; 3$. The anount of enzyme activity per $\mathrm{mg}$ protein, measured by carboxylation of exogenous substrate under standard conditions, were not significantly different; 4 . The anount of $\mathrm{CO}_{2}$ incorporation in the absence of exogenous substrate in carboxylase preparations from the warfarin-treated cows was about 40 times higher than in carbaxylase preparations from normal cows.

The cow is dissimilar to the rat in this respect, as it has been shown by Shah and Suttie (5) and confirmed by us (unpublished data), that in rat liver the amount of carboxylase increases during warfarin treathent, whereas in cow-liver this treatment did not affect the enzyme levell. As is known from the rat system (6-8), vitamin $k$ hydroquinone is required for the carboxylation reaction. When vitamin $k$ or vitamin $k$ epoxide is used, the vitamin must be reduced by its reductase before the carboxylation reaction can praceed. With the endogenous, and also exogenous substrate, the reduction of vitamin $k$ is the rate-limiting step, because the reduced form will always cause a substantially nigher activity, if the carboxylase activities obtained with equal amounts of oxidized and reduced forms are compared.

The carboxylase can function independently of the reductase, with both exogenous and endogenous substrates, because $20 \mu \mathrm{M}$ warfarin (which inhibits the reductase completely) will not inhibit the carboxylation if vitamin $k$ hydroquinone is present. On the other hand, the reductase can function independently of the carboxylase, because vitamin $K$ and its epoxide will still be reduced when no substrate for carboxylation is present (carboxylase preparations from normal cows, tested without exogenous substrate). If substrate is addded after preincubation with oxidized forms of vitamin $k$. the carboxylation proceeds as if vitamin $k$ hydroquinone was present. The amount of vitamin $K$ hydroquinone that were formed amounted to $10-50 \%$ of the $K_{m}$ value. Nevertheless, the carboxylation proceeded at its maximal reaction rate. This indicates that the newly-formed vitamin $K$ hydroquinone is not equally distributed within the microsomal membrames, but remains in high local concentrations in the enwironment of the carboxylase/reductase. Therefore, these two enzymes cannot be distributed aver the microsomal membrane remnants independent of each other, but have to be linked in such 
a way, that the vitamin $k$ hydroquinone produced by the reductase is chatmeled preferentially to the carboxylase.

In our experiments, we have not yet beer able to differentiate between the vitamin $k$-reducing enzyme and that reducing vitamin $k$-epaxide. Whether this means that both functions are fulfilled by the same enzyme, or enzyme systen renains to be investigated.

\section{Acknowledgment}

The authors acknowledge the aid of Or. A. Muijtjens for his help with the statistical analysis of their results.

\section{REFERENCES}

1. Carlisle, T.L., Shah, D.W. and Suttie, J.W. (1980) in Vitamin $k$ metabolism and vitamin K-dependent proteins (Suttie, J.W., ed), pp 443-449, University Park Press, Baltimore

2. Suttie, J.W. (1980) C.R.C. Crit.Rev.Biochem. 8, 191-223

3. Vemeer, C., Soute, B.A.M. and Hemker H.C. (1978) Biochim.Biophys.Acta $523,494-505$

4. Fieser, L.F., Tishler, M. and Sampson, W.K. (1941) J. Bioll. Chem. 137, 659-692

5. Shah, D.W. and Suttie, J.W. (1978). Arch. Biachem. Biophys. 191, 571-577

6. Sadowski, J.A., Schnoes, H.K. and Suttie, J.W. (1977) Biochemistry 16, $3856-3863$

7. Friedman, P.A. and Shia, M. (1976) Biochem. Biophys. Res. Comm, 70, 655-662

8. Girardot, J.M., Mack, D.0., Floyd, R.A. and Johnson, B.C. (1976)

Biochem. Biophys. Res. Comm. 70, 65-662 
CHAPTER 3

PREPARATION OF AN ACID-SOLUBLE SUBSTRATE FOR VITAMIN K-DEPENDENT CARBOXYLASE BY LIMITED PROTEOLYSIS OF BOVINE DESCARBOXYPROTHROMBIN.

This work has been published,

B.A.M. Soute, C. Vermeer, M. De Metz, H.C. Hemker and H.R. Lijnen (1981) Biochim. Biophys. Acta 676, 101-107 
Bowine descarboxyprothrombin and descarboxyfragement-1 can be used as substrates for rat and bovine vitamin K-dependent carboxylase. In both enzyme systems, however, these substrates have a high $k_{m}(0.3-0.4 \mathrm{mM})$. A better substrate $\left(K_{m}=0.001-0.003 \mathrm{~m} M\right)$ was prepared from bovine descarboxyprothrombin by limited a proteolysis with subtilisin Carlsberg. This substrate is called Fragment-5u and is composed of the amino acids 13-29 of descarboxyprothrombin.

\section{INTRODUCTION}

The vitamin $K$-dependent carboxylation reaction is generally studied with rat carboxylase prepared from warfarin-treated or vitamin K-deficient animals. Precursor proteins, which are substrate molecules for the witamin $K$-dependent carboxylase are present in those preparations and it has been demonstrated that prothrombin is synthesized from the precursors (1.2). It could however not be demonstrated with those preparations that purified hepatic prothrombin precursors were carboxylated (3).

During the last few years we have developed a cow liver cell-free system in which purified descarboxyporthrombin is converted into prothrombin, as measured with a coagulation assay $(4,5)$. The enzyme system was designated as prothrombin synthase and not as carboxylase, because parallet incorporation of ${ }^{14} \mathrm{CO}_{2}$ into descarboxyprathrombin could not unequivocally be demonstrated. This system is therefore unsuitable for measuring the carboxylation of various substrates and we preferred to use solubilized microsomes from the liver of normal cows for these studies. As has been pointed out in chapter 2 these microsomes hardly contain endogenous substrate for the vitamin $K$-dependent carboxylase, whereas the carboxylating activity towards exogenous substrates can be measured easily. In this chapter we describe the preparation of a low molecular weight fragment from bovine descarboxyprothrombin that may be used as a trichloroacetic acid-soluble substrate for both rat and bovine carboxylase. 
Chemicals and buffers. Buffer A: $0.15 \mathrm{M} \mathrm{NaCl} / 0.01 \mathrm{M} \mathrm{Tris-HCl}, \mathrm{pH} 7.5$. Vitamin $K_{1}$ was obtained from Hoffmann-La Roche (Switzerland). Triton $X-100$ and dithiotreitol (DTT) were from Sigma (USA). Proteases were obtained from Sigma (USA) and Boehringer (FRG). $\mathrm{NaH}^{14} \mathrm{CO}_{3}(60 \mathrm{mCi} / \mathrm{mmol})$ was purchased from the Radiochemical Centre Amersham (UK) and Aquasol- 2 was from New England Nuclear (USA). Vitamin $K$ hydroquinone was prepared as described in (4). The synthetic pentapeptide Phe-Leu-Glu-Glu-Leu was obtained from Vega Fox (USA). DEAE-Sephacel and CNBr-activated Sepharose were obtained from Pharnacia (Sweden) and proteins were coupled to the Sepharose according to the manufacturers prescription. Ultrogel was obtained from LKB (Sweden). A11 other chemicals were obtained from Merck (FRG).

Preparation of carboxylase. Soluble bovine carboxylase was prepared from the liver of non-anticoagulated cows. The crude microsomes, prepared as described in (4) were suspended in a buffer containing $0.8 \mathrm{M} \mathrm{NaCl}, 0.05 \mathrm{M}$ Tris-HC1 (pH 7.5), $1 \mathrm{mM}$ DTT, $0.5 \mathrm{mM}$ EDTA, 0.5\% Triton X-100 and 30\% ethylene glycol. The final protein concentration was $50 \mathrm{mg} / \mathrm{ml}$ and insoluble material was removed by centrifugation $(140.000 \times \mathrm{g}$ for $1.5 \mathrm{~h})$. The supernatant of this run was designated as soluble carboxylase. Sepharosebound carboxylase was prepared as described in chapter 4. Soluble rat carboxylase was obtained from anticoagulated female rats $(200-220 \mathrm{~g})$ of the Lewis strain. The rats were anticoagulated by the intraperitoneal adminstration of $2 \mathrm{mg}$ sodium warfarin in $0.9 \% \mathrm{NaCl} 18 \mathrm{~h}$ before being killed. The animals were killed by decapitation and the livers were removed, washed with $0.25 \mathrm{M}$ sucrose and used for the preparation of soluble carboxylase in a similar way as that described for the bovine system.

Measurement of carboxylase activity. Reaction mixtures $(0.25 \mathrm{ml})$ containing $0.1 \mathrm{ml}$ soluble carbaxylase $(3.5 \mathrm{mg}$ protein), $0.3 \mathrm{M} \mathrm{NaCL}, 0.05 \mathrm{M} \mathrm{Tris-HCl}$, $\mathrm{pH} 7.5,0,2 \%$ Triton $x-100,12 \%$ ethyleme glycol, $20 \mu \mathrm{Ci} \mathrm{NaH}{ }^{14} \mathrm{CO}_{3}, 2 \mathrm{mM}$ dithiothreitol, $100 \mu$ Mitamin $K$ hydroquinone and exagenous substrate as indicated were incubated at $25^{\circ} \mathrm{C}$ in parafilm-sealed tubes. The reaction was stopped at various interwals by diluting the samples with $2 \mathrm{~m} 1$ ice-cold buffer $\mathrm{A}$ and $2 \mathrm{ml} 10 \%$ trichloroacetic acid. After centrifugation, traces of 
unbound label were remowed from the supernatant by vacum extraction and the samples were counted in Aquasol-2 in a Packard Tricarb scintillation counter. The trichloroacetic acid-precipitates were dissolved in NaOH and reprecipitated three times before counting. The results are expressed as dpm pering of protein.

Preparation of purifjed substrates. Bowine dicoumarol plasma (4) was adsorbed with $\mathrm{BaSO}_{4}(200 \mathrm{~g} / 1)$ and descarboxyprothrombin was purified therefrom by chromatography on QAE-Sephadex, DEAE-Sephadex, hydroxylapatite and Sepahdex G-100. Bovine thrombin was obtained from Hoffmann-La Roche and was purified by chramatography on SP-Sephadex and benzamidin-agarose. Descarboxyfragment-1 was prepared by incubating purified descarboxyprothrombin and thrombin in a molar ratio of 10: 1 in buffer $\mathrm{A}$ at $37^{\circ} \mathrm{C}$ for 2 h. Descarboxyfragment-1 was resolved from the other components of the digest by chromatography on sephadex $G-100$ in $20 \%$ acetic acid as described by stenflo (6) and dialysed against buffer $A$.

Amino acid analysis, $\mathbb{N H}_{2}$-teminal sequence and end group determinations. Amino acid analysis was performed after hydrolysis in $6 \mathrm{M} \mathrm{HCl}$ in vacuo at $110^{\circ} \mathrm{C}$ for $20 \mathrm{~h}$ using a Beckman $119 \mathrm{CL}$ amino acid analyzer. $\mathrm{NH}_{2}$-terminal amino acid sequence analysis was performed as described by Edman (7). In some instance $\mu^{14}$ CB-phenylisiothiocyanate was used. Identification of the phenylthiahydantoins was performed by thim-layer chomatography (8). Radioactive derivates were identified with a Berthold scanner and quantitated by liquid scintillation counting. CoOH-terminal amino acids were determined by digestion with carboxypeptidase $\gamma$ (Pierce) and amino acid analysis (9). About 80 mmol of protein was dissolved in $0.05 \mathrm{M}$ sodium acetate buffer, $\mathrm{pH} 5.5$, to a protein concentration of about $1.6 \mathrm{mg} / \mathrm{mt}$. Digestion was performed at $25^{\circ} \mathrm{C}$ using an enzyme/substrate ratio of $1: 250$ (w/w) and sampling over a tine period of 5-90 min. The sample was kept in a boiling water bath for 3 min to inactivate the enzyme and diluted with 0.2 M sodium citrate buffer, pH 2.2, for analysis. 
When we tried to carboxylate exogenous substrates in a bovine carboxylating enzyme system, it resulted that at a concentration of $1.4 \mathrm{M}$ (plasma concentration) purified bovine descarboxyprothrombin did not affect the carboxylation reaction (Table 1) Descarboxyfactor $X$ also did not affect the carboxylation reaction at plasma concentration $(0.28 \mu \mathrm{M})$. Only at more than 70-fold higher concentrations of descarboxyprothrombin a significant increase of ${ }^{14} \mathrm{CO}_{2}$ incorporation was measured. In order to exclude the possibility that descarboxyprothrombin merely stimulates carboxylase without being carboxylated itself, we modified either the endogenous substrate or the exogenous one in such a way that they could easily be separated from each other after the carboxylation reaction had occurred. The three modification procedures that we used were: (a) preparing descarboxyfragment-1, which, in contrast to the endogenous substrate. is soluble in thrichlroacetic acid. (b) Cross-linking the descarboxyprothrombin to CNBr-activated Sepharose and (c) preparing Sepharose-bound carboxylase; in this partly purified system all endogenous substrate is linked to the solid phase and can thus be separated from the soluble exogenous descarboxyprothrombin (5, chapter 4 ).

Table I. The carboxylation of various substrates by rat and bovine carboxyzase

Mixtures containing rat and bowine carboxylase were incubated at $25{ }^{\circ} \mathrm{C}$ for 0.5 and $1 \mathrm{~h}$, respectively. The carboxylation by bovine carboxylase is presented in italicer.

\begin{tabular}{|c|c|c|}
\hline \multirow{2}{*}{ Substrate added } & \multicolumn{2}{|c|}{ Vitamin k-dependert incorponation of ${ }^{14} \mathrm{CO}_{2}$ in } \\
\hline & $\begin{array}{l}\text { "Trichloroacetic acid } \\
\text { precipitate }\end{array}$ & $\begin{array}{l}\text { Trichloroactevic acla } \\
\text { supernatant }\end{array}$ \\
\hline None & 252 & 1 \\
\hline Descarboxyprothront in $(1,4$ win) & 245 & 1. \\
\hline Descarboxppothrotivin $(0.1 \mathrm{~m})$ & 454 & 2 \\
\hline Descarboxyfragment-1 $(1.4$ w) & $26: 1$ & 3 \\
\hline Descarboxy fragnent-1 $(0.1 \mathrm{~mm})$ & 232 & 206 \\
\hline
\end{tabular}


When using descarboxyfragment-1 we observed that this substrate enhanced the carboxylation reaction in a similar way as descarboxyprothrombin did. Since the additional amount of incorporated label was present in the trichloroacetic acid-soluble fraction (Table I) it is obvious that descarboxyfragment-1 is carboxylated by the rat as well as by the boyine enzyme system. It resulted that rat carboxylase was also able to carboxylate the solid-phase descarboxyprothrombin (Sp-DP) in a vitamin $K$-dependent way (Table II). In the bovine system, however, it appeared that

Table II. The carboxylation of bovine deacarborymothromin by rat and bovine carboxylase

The concentration of exogenous substrate (Sp-DP) was $0.2 \mathrm{~m}$ shurry $(0.9 \mathrm{mg}$ of protein) per. m. reaction mixture. The incorporation of ${ }^{14} \mathrm{CO}_{2}$ into Sp-DP was measured after 1 in at $25{ }^{\circ} \mathrm{C}$ by filtering the reaction mixtures over glass-fiber filters, followed by extensive wasing with buffer A. The filters were counted in Aquasol and the results are expressed as dpri per ing of" protein. The concentration of solid-phage carboxylase (Sp-carboxylase) was 0.2 mil slurry $\left(0.05 \mathrm{~m}\right.$ of proteirs) per mil reaction mixture. The incorporation of ${ }^{14} \mathrm{O}_{2}$ into the soluble substrate was measured after if $h$ at $25^{\circ} \mathrm{C}$ by filtering the reaction mixtures over glass-fiber filters and counting the filtrate.

\begin{tabular}{|c|c|c|}
\hline \multirow{2}{*}{$\begin{array}{l}\text { Sepharase-bound } \\
\text { sulbitrete } \\
\text { A }\end{array}$} & \multicolumn{2}{|c|}{$\begin{array}{l}{ }^{14} \mathrm{CO}_{2} \text { incorporation by soluble rat carboxylase } \\
\text { into Sepharose-bound protein }\end{array}$} \\
\hline & +vitamin $x$ hydroquinone & -vitamin K thydroquinone \\
\hline None & 7 & 7 \\
\hline Descarboxyprothrombin & 116 & 20 \\
\hline Prothirombin & 14 & 12 \\
\hline Soluble gubstrate & \multicolumn{2}{|c|}{$\begin{array}{l}14 \mathrm{CO}_{2} \text { incorporation by Sepharose-bound bovine } \\
\text { carboxylase into soluble protein }\end{array}$} \\
\hline B & +vitamin K hydroquinone & - vitanin $\mathbb{K}$ hydroquinone \\
\hline None & 1370 & 982 \\
\hline Descarboxyprothronbin $(0.1 \mathrm{~mm})$ & 127000 & 1032 \\
\hline Prothrombin $(0.1 \mathrm{~mm})$ & 3185 & 1866 \\
\hline
\end{tabular}


the cross-1inking procedure had changed the descarboxyprothrombin in such a way that the SP-DP did not stimulate the carboxylation reaction any more and neither was it carboxylated itself. On the other hand, when the enzyme and its endogenous substrate were attached to the solid phase, soluble dexcarboxyprothrombin could be added to the enzyme system and it could be demonstrated that also in this case the exogenous substrate was carboxylated (Table $\mathbb{I}$ ).

The carboxylation of descarboxyprothrombin and descarboxyfragment-1 occurred with a very low efficiency, however, (see below) and we tried to prepare better substrates by degrading descarboxyprothrombin with Sepharose-bound proteases. Sixteen proteases were used and the effect of their fragmentation products on the ${ }^{14} \mathrm{CO}_{2}$ incorporation was measured in rat as well as in bovine carboxylase (Table III). By keeping the digested prothrombin at a concentration as 10 as $2.8 \mu \mathrm{M}$ we could rapidly screen the result of the limited proteolysis, because only strongly improved preparations possessed a demonstrable activity in the carboxylation reaction. From these experiments it became clear that four proteases (subtilis in Carlsberg, subtilisin BPN', pronase $P$ and proteinase $K$ ) were able to cleave a highly active fragment from descarboxyprothrombin. In all these cases the carboxylated reaction products were found in the tricholoroacetic acid supernatant, and when assayed on Ultrogel columns, all four substrates had a molecular weight which was lower than 5,000 d. We decided to purify and characterize the substrate that is obtained by the digestion of descarboxyprothrombin with Sepharose-bound subtilisin Carlsberg. This fragment was designated as Fragment-Su and it was purified from the digest by chromatography on DEAE-Sephacel, ACA 54 and Uitrogel A 202 columns (Fig.1).

The final purification was performed by HPLC-chromatography (Fig.?). The carboxylatable peptide was recovered in peak $c$. The amino acid composition of the purified peptide is sumarized in Table IV and is in agreement with the composition that is expected to be found from the anino acid residues 13-29 of descarboxyprothrombin (Fig.3.).

Fig. 3. Amino acids 13-29 of descarboxyprothrombin.

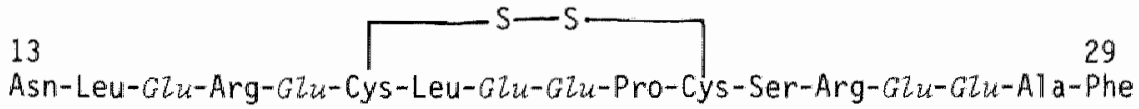


Table III. The carborylation of fragntented bovine descarboxyprothrombin by rat and bovine caxboxylase-

The various proteases were coupled to OHBr-activated sephanose and 1 mi slury weas

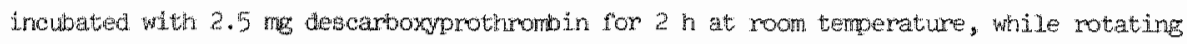

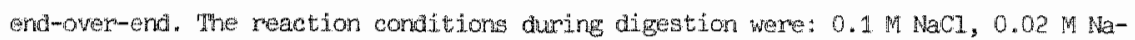
acetate buffer, 046.0 in the case of peosin and $0.1 \mathrm{MHaCl}, 0.02 \mathrm{M}$ Tris-HC1, pH 7.2 for all other proteres. Dumber the carboylation reaction the concentration of fragmanted subgtrate (15 added) was 200 ug/mil. The carboxylation by nat carboxylase and bowlne carboxylase (italros) was meastured after 60 min at $25{ }^{\circ} \mathrm{C}$; blank walues (without vitamin k) were substractor.

\begin{tabular}{|c|c|c|c|c|}
\hline \multirow{2}{*}{$\begin{array}{c}\text { Protease used for the } \\
\text { Pragnertation of } \\
\text { prothromisin }\end{array}$} & \multicolumn{4}{|c|}{ Vitamin K-dependene incorporation of ${ }^{14} \mathrm{CO}_{2}$ in } \\
\hline & \multicolumn{2}{|c|}{$\begin{array}{l}\text { Trichloroacetic acid } \\
\text { precipitate }\end{array}$} & \multicolumn{2}{|c|}{$\begin{array}{c}\text { Trichlomeacetic acid } \\
\text { supermateant }\end{array}$} \\
\hline None & 270 & 66 & 1 & 2 \\
\hline Tryosin & 335 & 62 & 5 & 15 \\
\hline Chymotrmysin & 198 & 63 & 6 & 38 \\
\hline Pepsin & 270 & 65 & 2 & 4 \\
\hline Papain & 292 & 87 & 4 & 17 \\
\hline Subtilisin Carlaberg & 219 & 37 & 37 & 159 \\
\hline Subtillisin BeN" & 229 & 45 & 24 & 170 \\
\hline Protease II & 279 & 63 & 5 & 28 \\
\hline Protease TV & 290 & 49 & 4 & 33 \\
\hline Pronase $\mathrm{P}$ & 216 & 40 & 11. & 98 \\
\hline Pronase A & 280 & 56 & is & 21 \\
\hline Clostripaine & 253 & 75 & 2 & 9 \\
\hline Froteinese $\mathrm{K}$ & 229 & 4 & 39 & 212 \\
\hline Thermolysin & 272 & 55 & 0 & 32 \\
\hline No substrate added & 266 & 68 & 3 & 2 \\
\hline
\end{tabular}


Fig. 1. Fractionation of digested descarbowyprothronbin.

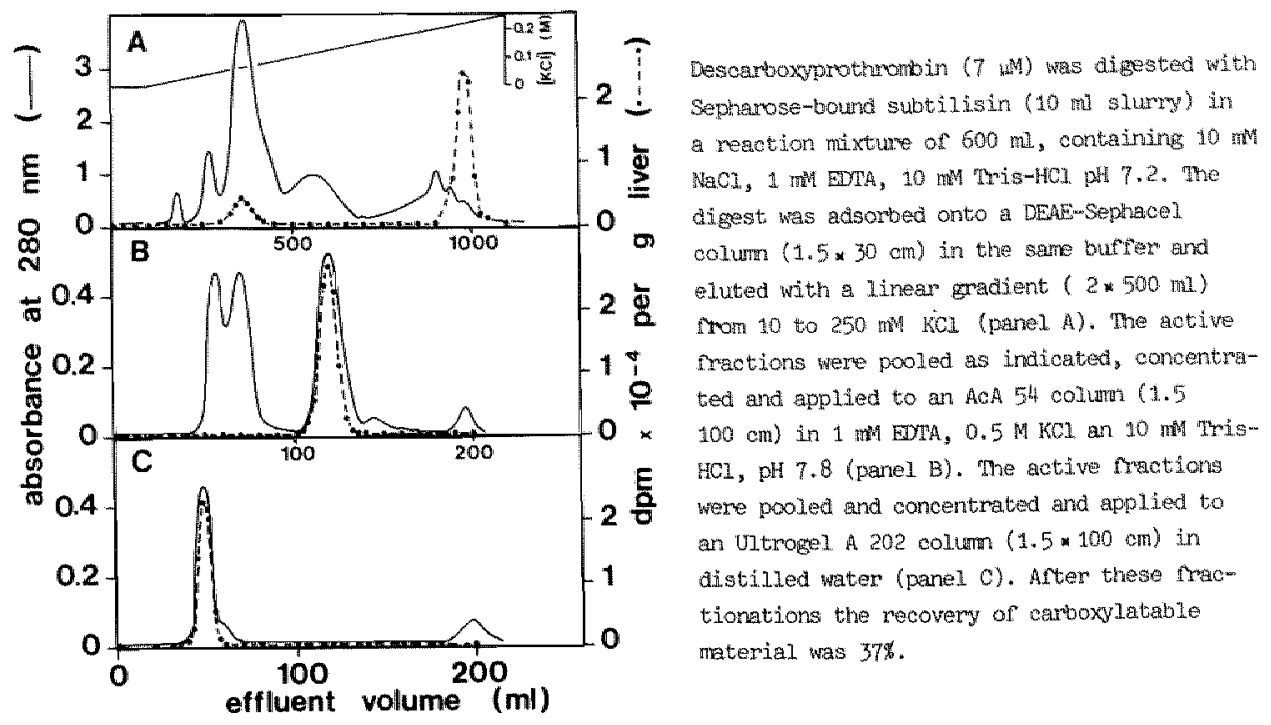

Fig. 2. Purification of Fragment-Su by HPLC-chromatograpiny.

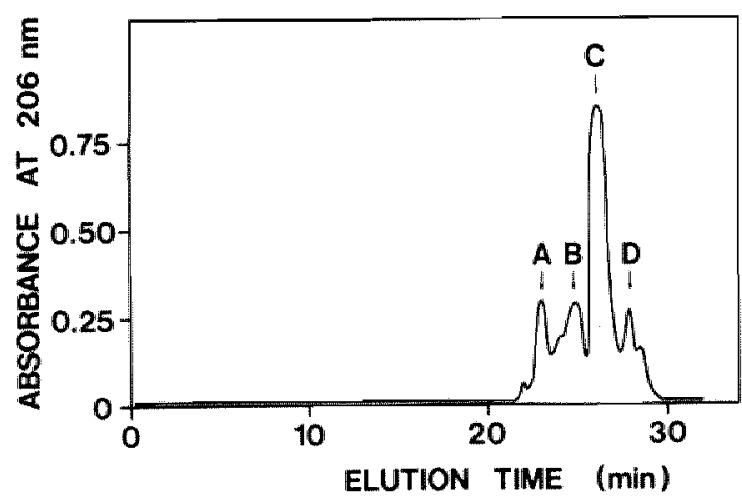

The protein solution was adsorbed to an ultrasphere-ODS $(5, \mu M)$ colum $(25.1 \mathrm{~cm}$, Beclumen) and aradient was applied rom $0-30 \% \mathrm{CH}_{3} \mathrm{OH}$ in $0.1 \% \mathrm{H}_{3} \mathrm{PO}_{4}$. The peake were eluted wh a flow rate of 4 mith par m and assayed as domoribed in the text. The recovery of purifled pragment-Su was 0.26 mol per" mol descarboynprom thrombin. 
Table IV. Amino actid compodition of fragnent - Su.

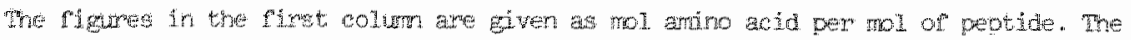
second solum repreatert the composition expeted fron the geguence $13-29$ of descarboxprothwein.

\begin{tabular}{|c|c|c|}
\hline Armino acid & Conposition observed & Cortosition empected \\
\hline $\mathrm{AgP}$ & 1.1 & 1 \\
\hline Thr & 0 & 0 \\
\hline $\operatorname{Ser} x$ & 0.8 & $\mathbb{1}$ \\
\hline$d n$ & 6.2 & 6 \\
\hline Pro & 1.3 & 1 \\
\hline diy & 0.2 & 0 \\
\hline Mla & 1.0 & 1 \\
\hline val & 0.1 & 0 \\
\hline Met & 0 & 0 \\
\hline Ile & 0 & 0 \\
\hline Leu & 2.0 & 2 \\
\hline Myr & 0.1 & 0 \\
\hline Phe & 1.0 & 1 \\
\hline His & 0 & 0 \\
\hline Lys & 0 & 0 \\
\hline Arg & 2.0 & 2.0 \\
\hline
\end{tabular}

Table $V$. The kinetic constants of various swbstrates for rat and bovine carboxyzase.

The $\mathrm{K}_{\mathrm{m}}$ and $\mathrm{W}$ were caloulated from the initial rates at various concentrations of the substrates. The $V$ is expressed in dpm incorporated per min per mis of protein. Further details are as described in Materials and Methods.

Dowine carboxylase

Substrate

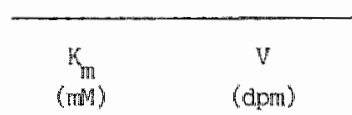

Rat canoxymse

\begin{tabular}{lc}
\hline $\begin{array}{c}K_{\mathrm{m}} \\
(\mathrm{m})\end{array}$ & $\begin{array}{c}\mathrm{w} \\
(\mathrm{wgm})\end{array}$ \\
0.3 & 123 \\
0.3 & 195 \\
0.003 & 150 \\
8 & 95
\end{tabular}


Quantitative amino acid analysis revealed that Asn was the N-teminal residue with a yield of 0.86 mol per mol peptide. The sequence of the amino acid residues at the $N$-terminal side was found to be: Asn-Leu-Glu-Arg and at the C-teminal position we found Phe in 0.93 mol per mol of peptide. This confirmed that Fragment-Su is identical to the amino acid sequence 13-29 in descarboxyprothrombin.

In order to demonstrate that the incorporated label in the carboxylated Fragment-Su was present in gla-residues, we prepared a carboxylating reaction mixture $(1 \mathrm{ml})$ containing 10 $4 \mathrm{~g}$ of the peptide fragment. After 1 h at $25^{\circ} \mathrm{C}$ the proteins were precipitated with trichloroacetic acid and non-bound ${ }^{14} \mathrm{CO}_{2}$ was removed (see Materials and Methods). The trichloroacetic acid supernatant contained carboxylated Fragment-\$u $(98,512$ dpm). After acid hydrolysis in $6 \mathrm{M} \mathrm{HCl}$ in vacuo at $110^{\circ} \mathrm{C}$ for $20 \mathrm{~h}$ about $50 \%$ of the label (51326 dpm) had disappeared, showing that the gla-restolues had been decarboxylated into glu. Finally, we compared the kinetic canstants of descarboxyprothrombin, descarboxy-fragment-1, Fragment-Su and the synthetic pentapeptide Phe-Leu-G1U-G1 u-Leu (Table V). The $K_{m}$ of Fragnent-Su was 0.001 $m M$, whereas the $k_{m}$ of the other three substrates ranged from 0.4 to $11 \mathrm{~mm}$. comparison of the maxiamal carboxylation rates (V) showed that these were all of the same order of magnitude. Therefore, it has to be concluded that Fragment-Su is a better substrate than any of the other exogenous substrates.

\section{DISCUSSION}

When bovine descarboxyprothrombin and descarboxyfragment-1 were added to a rat liver vitamin $K$-dependent carboxylase, both substrates were carboxylated. This could be demonstrated by separating the ${ }^{14} \mathrm{C}$-labeled exogenous substrates from the reaction mixtures. These experiments exclude the possibility that the added substrates act by promoting the corversion of endogenous substrates.

In bovine liver carboxylase the presence of descarboxyprothrombin and descarboxyfragment-1 induced an increase of the ${ }^{14} \mathrm{CO}_{2}$ incorporation which was similar to that in the rat system. Because descarboxyfragment-1 is not precipltated with trichloroacetic acid, it is separated from the endogenous 
substrates in the reaction mitures and it could thus be shown that also in this case the exogenous substrate was carboxylated. Insolubilized substrates, however, had lost their ability to stimulate the carboxylation reaction. On the other hand, when we used Sepharose-bound carbaxylase and soluble descarboxyprothrombin, $" t$ could be demonstrated that bovine carboxylase, as well as rat carboxylase, is able to carboxylate this substrate.

Both in the rat and in the bovine system we abserved high $K_{m}$ values for descarboxyprothrombin and for descarboxyfragment-1. This means that high concentrations $(0.5-1 \mathrm{mM})$ of these substrates have to be added to carboxylase in order to be able to measure their carboxylation. It is not probable that the endogenous substrates are present in our carboxylase preparations in these quantities and therefore the endogenous substrates must be far better substrates than the exogenous ones. Possible reasans for this phenomenon might be: (a) The main part of the endogenous substrates does not consist of prothrombin precursors and prothrombin precursors are carboxylated rather poorly. (b) Descarboxyprothrombin from plasma differs from liver prothrombin precursors (e.g. because the latter contain a signal-peptide* (10) at the $N$-terminal side of the molecule). (c) In vivo prothrombin precursors are carboxylated during protein synthesis. After completion of the peptide chain sterical hindrance hampers the carboxylation reaction. (d) In wivo the carboxylation of prothrombin precursors is followed by a second modification (e.g. glycosylation). This second modification occurs independent of the carboxylation reaction and hampers the carboxylation of descarboxyprothrombin.

since it is known that at least $25 \%$ of endogenous reaction product of rat and bovine carboxylase consists of prothrombin $(1,2$, chapter 4$)$, the possibility mentioned under (a) will not be considered. Furthermore it: cannot be excluded that the signal-peptides mentioned under (b) have an effect on the in witro carboxylation, but direct investigations are hampered by the lack of experimental possibilities. If however, the structure of the completed descarboxyprothrombin hinders the carboxylation reaction (c) and/or (d), it should be possible to remove the main part of the descarboxyprothrombin molecule in order to abtain a substrate that would be more accessible to carboxylase. The removal of fragment- 2 and thrombin (resulting in descarboxyfragment-1) did not change the kinetic 
characteristics of the endogenous substrate. Only proteolytic degradation of the latter to a peptide containing the amino acids 13-29 resulted in a substantial improwement of the substrate. It is intriguing that the structure of this peptide contains all information which is required for a good substrate, whereas this information is lost in a number of smaller synthetic peptides (11). It may be expected therefore, that further proteolytic cleawage of Fragnent-Su will worsen this substrate although it is still to be investigated whether all its 17 amino acids are required for a good carboxylation reaction.

*

Many secreted proteins are synthesized as precursors having an $\mathrm{MH}_{2}$-teminal extension. This extension (10-30 amino acids long) is very rich in hydrophobic residues and has been termed the signal peptide.

\section{REFERENCES}

1. Esmon, C.T., Sadowski, J.A. and Suttie, J.W. (1975) J.Biol.Chen. $250,4744-4748$

2. Graves, C.B., Grabau, G.G., 01son, R.E. and Munns, T.W. (1980) Biochemistry $19,266-272$

3. Suttie, J.W. (1980) C.R.C. Crit.Rev.Biachem. 8,191-223

4. Vermeer, C., Soute, B.A.M. and Hemker, H.C. (1978) Biochim.Biophys.Acta $523-494-505$

5. De Metz, M., Vermeer, C., Soute, B.A.M. and Hemker, H.C. (1980) in Vitamin $K$ metabolism and vitamin $K$-dependent proteins, (Suttie, J.W., ed.) pp.560-570, University Park Press, Baltimore

6. Stenflo, J. (1973) J.Biol.Chem. 248,6325-6332

7. Edman, P. and Henschen, A. (1975) in Protein Sequence Determination (Needleman, S.B., ed.), pp. 232-279, Springer Verlag, Berintn

8. Wiman, B. (1977) Eur.J.Biochem. 76,129-137

9. Hayashi, R., Moore, S. and Stein, W.H. (1973)J.Biol.Chem. 246,2296-2302

10. MacGillivray, R.T.A., Chung, D.W. and Davie, E.W. (1980) in Vitamin K metabolism and vitamin K-dependent proteins (Suttie, J.W.,ed.) 546-552, University Park Press, Baltimore 
11. De Metz, M., Vermeer, C., Soute, B.A.M. van Scharrenburg, Slotboom, A.J. and Hernker, H.C. (1981) FEBS Lett. 123, 215-218

12. Pich, ח.H., Lehrman, S.R., Kawai, M., Goodman, H.L. and Suttie, J.H. (1980) in Vitamin $K$ metabolism and vitamin $K$-dependent protein (Suttie, J.W., ed.), pp. 471-479, University Park Press, Baltimore. 
CHAPTER 4

PARTIAL PURIFICATION OF BOVINE LIVER VITAMIN K-DEPENDENT CARBOXYLASE BY IMMUNOSPECIFIC ADSORPTIOH ONTO AMTIFACTOR-X.

This work has been published, M. de Metz, C. Vermeer, B.A.M. Soute, G.J.M. van Scharrenburg, A.J. Slatboom and H.C. Hemker (1981) FEBS Lett. 123, 215-218 
The endagenous substrate for the vitamin k-dependent carboxylase, which accumulates in liver from warfarin-treated cows, consists mainly of precursors of prothrombin $( \pm 20 \%)$ and factor $x( \pm 70 \%)$. The carboxylase could be purified from the crude microsomal fraction a 100 fold by solubilization with Triton $x-100$ and immunospecific adsorption to antibodies against its endogenous substrate (precursors of factor $x$ ).

INTRODUCTION

Adminstration of vitamin $K$-antagonists induces the appearance of abnormal clotting factors in the blood (man, cow) or in the liver (rat). These abnormal clotting factors (descarboxyfactors) contain glutamic acid (G1 U) residues instead of the $\gamma$-carboxyglutamic acid (Gla) residues, which occur in normal clotting factors (1). In human and bovine plasma $90 \%$ of the abnormal proteins consists of descarboxyprothrombin. Attempts to identify the rat liver abnormal proteins have been done in an in vitro vitamin $K$-dependent carboxylating enzyme system (carboxylase) and it was shown that only $25 \%$ of the carboxylated endogenous substrates bind to antiprothrombin antibodies (2).

Here, we describe the results of our investigations concerning the distribution of the various clatting factor precursors in preparations of vitamin $k$-dependent carboxylase from liver of warfarin-treated cows.

MATERIALS AND METHODS

Preparation of coagulation factors and antibodies. Bovine prothrombin was prepared and purified as in (3), factor $I X$ as in (4) and factor $X$ according to (5). The various coagulation factors were detected with the aid of onestage coagulation assays (6-8). Antibodies against these proteins were raised in goats and extracted from the various sera by immunospecific adsorption to the respective Sepharose-bound antigens. The purified antibodies were eluted from the solid phase with 3 M NaCNS and gave single 
precipitation limes against normal reference plasma in an Ouchterlony diffusion test (9). These antibodies wer coupled to chBr-activated Sepharose (Pharmacia). Antiprothrombin-Sepharose slurry (1 ml) was able to neutralize the prothrombin content of $8 \mathrm{ml}$ plasma. For antifactor IX-Sepharose and antifactor $X$-Sepharose these figures were $5 \mathrm{ml}$ and $9 \mathrm{ml}$, respectively. The various antibody preparations did not bind detectable amounts of any of the other coagulation factors.

Preparation of carboxylase One year old cows were anticoagulated by the oral administration of warfarin ( $5 i \mathrm{gma}, 10 \mathrm{mg} / \mathrm{kg}$ daily) during 1 week. Cows were slaughtered and microsomes were prepared from the livers of normal and anticoagullated animals as in (10). The crude microsomes were suspended in a buffer containing $0.05 \mathrm{M} \mathrm{KCl}, 0.02 \mathrm{M} \mathrm{Tris-4Cl} \mathrm{(pH} \mathrm{7.5)} \mathrm{and} 0.1 \%$ Triton $X-100$. After centrifugation at $100,000 \times \mathrm{g}$ for $1 \mathrm{~h}$ the pellet was solubilized by adding a buffer containing $1 \mathrm{M} \mathrm{KCl}, 0.02 \mathrm{MTris}-\mathrm{HCl}(\mathrm{pH} 7.5), 1$ $\mathrm{mM}$ OTT, $0.5 \mathrm{mM}$ EDTA and $0.5 \%$ Triton $X-100$. The final protein concentration was $15 \mathrm{mg} / \mathrm{ml}$ and insoluble material was removed by centrifugation (1 40000 $x \mathrm{~g}$ for $1.5 \mathrm{~h})$. The supernatant of this run was designated as soluble carboxylase.

Measurement of carboxylase activity Unless indicated otherwise the vitamin K-dependent incorporation of ${ }^{14} \mathrm{CO}_{2}$ was measured by incubating soluble carboxylase (1 $\mathrm{mg}$ protein) and $20 \mu \mathrm{Ci} \mathrm{NaH}^{14} \mathrm{CO}_{3}$ (Radiachemical Centre, Amersham) in reaction mixtures $(0.25 \mathrm{ml})$ containing $0.15 \mathrm{M} \mathrm{NaCl}, 0.02 \mathrm{M}$ Tris-HCl (pH 7.5), $1 \mathrm{mM}$ DTT, $0.2 \mathrm{mM}$ EDTA and $0.2 \%$ Triton $X-100$. The reaction was started by adding $1.5 \mu \mathrm{g}$ chemically reduced vitamin $\mathrm{K}_{1}(11)$ and the mixtures were incubated for $1 \mathrm{~h}$ at $25^{\circ} \mathrm{C}$ in sealed tubes. The reaction was stopped with $2 \mathrm{ml}$ thrichloroacetic acid $(10 \%)$ and the precipitates were washed and counted. The acid-soluble substrate Phe-Leu-Giu-Glu-Leu was prepared according to (12) and when it was present in the reaction mixtures the trichloroacetic acid supernatants were degassed at elevated temperatures before counting.

Gel electrophoresis and protein determination

SDS-polyacryll amide gel electrophoresis was performed according to (13). Gels containing labeled products were sliced with a Gilson gel slicer and counted. Non-labeled gels 
were stalned with coonassie blue. Protein concentrations were determined according to (14). The protein content of immobilized carboxylase was determined after elution of the solld phase with 6 M urea in $2 \% 50$.

\section{RESULTS AHD DISCUSSION}

In soluble rat carboxylase the incorporation of ${ }^{14} \mathrm{CO}_{2}$ in endogenous substrates is increased at least 20 -fold when the rats are treated with warfarin $18 \mathrm{~h}$ before preparing the liver homogenates. We obserwed that in soluble carboxylase obtained from warfarin-treated cows the carboxylation of endogenous substrate was 16-fold higher (3000 dpm per $\mathrm{mg}$ of protein) than in carboxylase from normal cows $(180 \mathrm{dpm} / \mathrm{mg}$ protein). These results suggested, that also in the cow liver some endogenous substrate (presumably clotting factor precursors) is accumulated during warfarin treatment and we

Table 1. Tmmospecific adsoxption of acrbaxylated reaction products.

Vitamin K-dependent incorponation of ${ }^{14} \mathrm{CO}_{2}$ was performed in standard reaction mixtures (1. mi). After incubation for $1 \mathrm{~h}$ at $25^{\circ} \mathrm{C}$, sepharose-bound antibodies $(0.4 \mathrm{ml}$ slurry) were added to the various reaction mixtures and the tubes were rotated end-over-end owermight at $4^{\circ} \mathrm{C}$ with 2 Triton $\mathrm{X}-100$. The Sepharose beads were washed altermately 3 tines with $1 \mathrm{M} \mathrm{NaCl}$ in $0.1 \mathrm{M}$ acetate buffer ( $\mathrm{pH} 4.0$ ) and with $1 \mathrm{M} \mathrm{NaCl}$ in $0.1 \mathrm{M}$ borate buffer (pH 6.0). Subsequently they were eluted with $6 \mathrm{M}$ wrea in $2 \% \mathrm{SDS}$, dialyzed against $0.1 \mathrm{M} \mathrm{NaCl}$ and counted. Non-adsorbed reaction mixtures (100\%) contained $12,300 \mathrm{dmm}$. Doubling the amount of Sepharose-bound antibodies did not affect the amount of adsorbed proteins.

\begin{tabular}{|c|c|c|c|c|}
\hline \multirow[t]{2}{*}{$\begin{array}{l}\text { Sepharose-liriked } \\
\text { adsorbant }\end{array}$} & \multicolumn{2}{|c|}{$\begin{array}{l}{ }^{14} \mathrm{co}_{2} \text { incorporated into } \\
\text { non-adsorbed protieins }\end{array}$} & \multicolumn{2}{|c|}{$\begin{array}{l}14 \mathrm{CO}_{2} \text { incorporated into } \\
\text { adsorbed proteins }\end{array}$} \\
\hline & dpm & $\%$ & $\mathrm{dpm}$ & \% \\
\hline a) Ant lprothmom in & 9680 & 78.7 & 2595 & 21.2 \\
\hline b) Ant 2 -factor $X$ & 3628 & 29.5 & 8511 & 69.2 \\
\hline c) Anti-factor $\mathbb{I X}$ & $114+14$ & 92.8 & 959 & 7.8 \\
\hline d) $a+b+c$ & 1451 & 11.8 & 10860 & 88.3 \\
\hline e) Albumirn & 11795 & 95.9 & 37 & 0.3 \\
\hline
\end{tabular}


therefore used carboxylase from anticoagulated cows for our studies concerning the nature of the bovine endogenous substrate.

Because of the presence of abundant proteolytic activity in bovine liver homogenates a direct determination of clotting factor precursors (e.g. with smake venoms) was not possible. In order to establish the nature of the endogenous substrate we therefore analyzed the ${ }^{14} \mathrm{C}$-labeled products that were formed during the carboxylation reaction. The analysis was performed by adsorption to inmobilized antibodies and, as is shown in table 1 , the main part $(69 \%)$ of the reaction product consists of factor $X-1$ ike material, whereas antiprothrombin and antifactor IX bound 21 and $8 \%$ of the incorporated label, respectively. In a second experiment the factor $x-1$ ike material was eluted from the antibodies and characterized further with the aid of SDS-polyacrylamide gel electrophoresis before and after reduction of the samples (fig.1). The non-reduced samples (A) showed a single band with $M_{r} 55,000$, which is in agreement with that of factor $x(5,14)$. The app. $M_{r}$

Fig. 1. Sodizmdodecyleulphate-polyacrylamide gelelectrophoresis of carboxylated endogenous substrates.

Reaction mixtures $(0.5 \mathrm{ml})$ were incubated for $1 \mathrm{~h}$ at $25^{\circ} \mathrm{C}$, mixed with $0.5 \mathrm{ml}$ antifactor$\mathrm{x}$-Sepharose and rotated end-over-end at $4{ }^{\circ} \mathrm{C}$ overnight. The Sepharose was washed as described in the legend to table 1 and the labeled antigens were eluted with $3 M$ NaCNS and dialyzed against $0.15 \mathrm{NaCl}$. The samples $\mathrm{C}$ and $\mathrm{D}$ were incubated at $37^{\circ} \mathrm{C}$ for $1 \mathrm{~h}$ with snake venom $\left(\mathrm{RW}_{\mathrm{x}}\right.$ ) and SDS was added to all sarples to $1 \%$ final concentration. (A) Non-reduced sample; (B) sample, reduced with $5 \%$ mercaptoethanol before electrophoresis; (C) non-reduced sample after treatment with FW, (D) sample treated with $\mathbb{R W V}_{\mathrm{x}}$ before reduction.

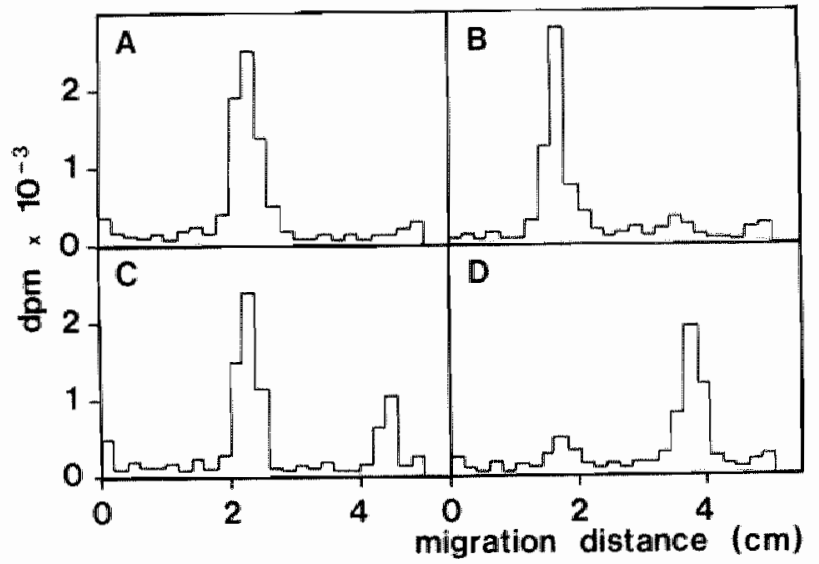


of the reduced protein (B) was found to be 65,000, which is higher than in the non-reduced gels and which shows that the factor $X-1$ ike material consists of one single polypeptide chain. It turned out that E.carinatus venorn, which is activating prothrombin, did not change the observed relative molecular masses (not shown). On the other hand the purified factor X-activating enzyme from Russell's viper venom (RVV $X$ ) induced a small amount of low M muterial $(15,000)$ in the non-reduced gel (C) whereas in the reduced sample (0) nearly all high $M_{r}$ material had disappeared and was recovered at a position indicating an $M_{r}$ of 25,000 . We concluded that the factor $x$-like material is a factor $x$-precursor consisting of one polypeptide chain.

After cleavage of this chain by RW $x$, the molecule is helld together by a disulfide bridge, which can be broken by reducing agents. Because the reaction mixture in which the carboxylation occurs is also slightly reducing, a small amount of low $M_{r}$ material is observed in the non-reduced sample. The increase of the app. $M_{r}$ in the reduced gels seems to be almost entirely due to changes in the light-chain material. A similar observation was made for the light chain of factor $X(15,16)$. As plasma factor $X$ contains two peptide chains, in vivo the carboxylation of the precursor probably precedes the conversion of one-chain factor $x$ into two-chain factor $x$.

Taking into consideration that in bovine plasma circulating prothrombin and factor $X$ are 1.4 and $0.28 \mu M$, that their half-life times are $80 \mathrm{~h}$ and $30 \mathrm{~h}$, respectivelly, and that factor $x$ contains 2 more Gla residues than does prothrombin, it may be calculated that in vivo at least 1.5 more carboxylation reactions accur in prothrombin precursors than in factor $X$ precursors. The experiments described above demonstrate that this situation is reversed in the in witro camboxylating enzyme system. The relative abundance of factor $X$ precursors in the carboxylase complex may be caused by a relatively high affinity of carboxylase for this substrate. During the preparation of the liver microsomes unbound factor $X$ precursors might then displace other clotting factor precursors, present in the enzyme complex. A second possibility is that the prothrombin precursors are more susceptible to proteolytic degradation which may occur during the preparation of the microsomes. The available data provide no basis for distinguishing between these possibilities. 
Since we knew that the endogenous substrate for the in vitro carboxylation reaction mainly consisted of precursors of factor $x$ (69:) and prothrombin (21\%), we started experiments in which we extracted the crude soluble carboxylase preparation with Sepharose-bound antibodies against factor $x$ and prothrombin, respectively. Treatment with antiprothrombin removed $20 \%$ of the carboxylase activity, whereas antifactor $x$ was able to bind as much as $62 \%$ of the total amount of carboxylase. A substantial amount of carboxylase activity was recovered on the sepharose beads and because most of the microsomal proteins were remowed by the washing procedure, the bound enzyme complex had been purified considerably. Solid phase carboxylase was assayed in the absence of Triton $X-100$ since detergents strongly inhibit its activity, even at low concentration. A summary of the purification scheme is given in table 2 .

Tabie 2. Pumification of bovine vitamin K-dependent amboxylase.

Purification of bovine vitamin $\mathrm{k}$-cependent carboxylase. The protein content of irmobilized carboxylase was determined after alution of the solid phase with $6 \mathrm{M}$ urea in $2 \%$ SDS. The carboxylation of endogenous substrate was neasured in the various carboxylase preparations after $1 \mathrm{~h}$ incubation at $25^{\circ} \mathrm{a}$. When the carboxylase activity was measured with Phe-Leu-Glu-GIu-Leu the rinal purification was 115-fold.

\begin{tabular}{lcccc}
\hline Stage & $\begin{array}{c}\text { Protein } \\
\text { (mg) }\end{array}$ & $\begin{array}{c}\text { Spec. activity } \\
\text { (dprimg) }\end{array}$ & $\begin{array}{c}\text { Recovery } \\
(\%)\end{array}$ & $\begin{array}{c}\text { Purification } \\
\text { (-fold) }\end{array}$ \\
\hline Crude microsomes & 2400 & 1420 & 100 & 1 \\
Washed microsomes & 1800 & 1885 & 110 & 1.5 \\
Soluble carboxylase & 1100 & 3006 & 97 & 2.1 \\
Imobillized carboxylase & 5 & 137276 & 20 & 97 \\
\hline
\end{tabular}


1. Stenflo, 1., Fernlund, P., Egan, W. and Roepstorff, P. (1974) Proc. Nat7. Acad.Sci.USA 71, 2730-2733

2. Willinghar, A.K., Martinn, S.L., Graves, C.B., Graham, G.G. and Munns, T.W. (1980) in: Vitamin $K$ metabolsim and vitamin $K$-dependent proteins (Suttie. A.h. ed) pp.553-559, University Park Press, Baltimore.

3. Dwen, M, G. Esmon, C.T. and Jackson, C.M. (1974) J.Biol.Chem. $249,594-650$

4. Fujikawa, K. "Thompson, A.R., Legaz, M.E., Meyer, R.G. and Davie, E.W. (1973) Biochemistry 12, 4938-4945

5. Fujikawa, K., Legaz, M.E. and Dawie, E.W. (1972) Biochemistry 11, 4882-4891

6. Vermeer, C., Soute, B.A.M. and Hemker, H.C. (1978) Thrombos.Res. 12, $713-716$

7. Veltkamp, A.J., Drian, E.F. and Loeliger, E.A. (1968) Thromb. Diathes. Haemorrh. $19,403-422$

8. Vermeer, C., Soute, B.A.M. and Hemker, H.C. (1979) Thromb.Res. 14, $679-685$

9. Duchterlony, 0, (1962) Progr.A1lerg. 6, 30-154

10. Vermeer, C. Soute, B.A.M. and Hemker, H.C. (1978) Biochim.Biophys.Acta $523,494-505$

11. De Metz, M., Vermeer, C., Soute, B.A.M. and Hemker, H.C. (1980) in:" Vitamin $K$ metabolism and vitamin $K$-dependent protein (Suttie, J.W. ed) pp. 560-570, University Park Press, Paltimore,

12. Suttle, J.W., Hageman, J.M., Lehrman, S.R. and Rick, D.H. "(ryro) J.B 101. Chem. $251,5827-5830$.

13. Laemm1 1 , U.K. (1970) Nature 227, 680-685

14. Lowry, D.H., Rasebrough, N.J., Farr, A.L. and Randa11, R.J. (1951) d. Biol. Chem. 193, 265-275

15. Wackson, C.M. (1972) Biochemistry 11, 4873-4881

16. Lindhout, M.J., Kop-Klaassen, B.H.M., Kop, J.M.M. and Hemker, H.C. (1978)Biochim. Biophys. Acta 533, 302-317 


\section{CHAPTER 5}

PROPERTIES AND CHARACTERIZATION OF SOL ID PHASE CARBOXYLASE 
With Sp-carboxylase the carboxytation of Phe-Leu-Glu-Glu-Leu proceeds with a linear rate for at least $3 \mathrm{~h}$. The properties of the carboxylation reaction with $5 p$-carboxylase are similar to those found with solubilized microsomes from cow and rat liver. Sp-carboxylase contains several different proteins, as analyzed with SDS polyacrylamide gelelectorphoresis. Two proteins $\left(M_{r} 45,000\right.$ and $\left.M_{r} 30,000\right)$ have vitamin $K$ binding capacity. The carboxylase can be partly eluted from the solid phase, but further purification has not been achieved.

INTRODUCTION

In chapter 4 a 100 fold purification of vitamin $K$-dependent carboxylase from the microsomal fraction has been described. The purified enzyme is still attached to Sepharose beads and is therefore called: solid phase carboxylase (Sp-carboxylase). In this chapter some properties of the SP-carboxylase will be presented.

\section{MATERIALS AMO METHODS}

Materials. Vitamin $K$, was obtained from Hoffman-LaRoche (Switzerland). ${ }^{3}$ labeled vitamin $K$ was a kind gift from Hoffmann-LaRoche. 2-chloro-3-phytylnaphtoquinone (chloro-K) was a kind gift of dr. J.W. Suttie. Triton $x-100$, p-hydroxymercuribenzoate, dithiothreitol, warfarin, vitamin $E$, superoxide dismutase and horse radish peroxidase were obtained from Sigma (USA). $\mathrm{NaH}^{14} \mathrm{CO}_{3}(40 \mathrm{Ci} / \mathrm{mol})$ and Aquasol-2 were purchased from New England Nuclear (UK), the synthetic peptide Phe-Leu-Glu-Glu-Leu from Vega Fox (USA) and pyridoxalphosphate and catalase from Boehringer (FRG). DEAE-Sephadex was obtained from Pharmacia (Sweden) and ACA 22 from LKB (France). All other chemicals were from Merck (FRG). Vitamin $K$ epoxide and vitamim $K$ hydroquinone were prepared as described earlier (1).

Buffer A: $0.15 \mathrm{M} \mathrm{NaCl}, 20 \mathrm{mM}$ Tris $-\mathrm{HCl}$ pH 7,5,0.5 mM EDTA. 
Preparation of carboxylase. Solid phase carboxylase (Sp-carboxylase) was prepared from the liver of warfarin-treated cows as described in chapter 4. The enzyme could be resolubilized from the sepharose beads by having the camboxylation reaction proceeded in buffer $A$ with 2 m dithiothreitol, 0.2 $\mathrm{mM}$ witamin $\mathrm{K}$ hydroquinone, $4 \mathrm{mM}$ Phe-Leu-Gilu-Glu-Leu and $5 \mathrm{mM} \mathrm{NaHCO}$ for $5 \mathrm{~h}$ at $25^{\circ} \mathrm{C}$. After incubation $1 \mathrm{M} \mathrm{NaCl}$ was added and the eluted carboxylase was dialyzed against buffer $A$ before use.

Measurement of carboxylase activity. The vitamin k-dependent incorporation of ${ }^{14} \mathrm{CO}_{2}$ was measured by incubating reaction mixtures $(0.25 \mathrm{ml})$ in buffer $A$ containing $0.1 \mathrm{ml}$ Sp-carboxylase $(40, \mu g$ protein) or 10 ug resolubilized carboxylase, $20 \mu \mathrm{Ci} \mathrm{NaH}^{14} \mathrm{CO}_{3}, 2 \mathrm{mM}$ dithiothreitol, and $0.2 \mathrm{mM}$ witamin $\mathrm{K}$ hydroquinone at $25^{\circ} \mathrm{C}$. When the carboxylation of exogenous substrate was measured, Sp-carboxylase was preincubated in the presence of non labeled $\mathrm{NaHCO}_{3}$ for $90 \mathrm{~min}$, washed with buffer $A$ and then assayed as described above. The reaction was stopped with $2 \mathrm{ml}$ icecold trichloroacetic acid $(10 \%)$ and the precipitates were washed and counted in Aquasol-2 in a Packard Tricarb scintillation counter. The trichloroacetic acid supernatants were degassed at elevated temperatures before counting. When the t-butyllhydroperoxide-dependent carboxylation was assayed, the incorporation of ${ }^{14} \mathrm{CO}_{2}$ into endogenous and exogenous substrate was measured together.

Protein determination and SDS polyacrylamide gelelectrophoresis. Protein concentrations were detemined according to Lowry et al (2). SDS polyacrylamide gelelectrophoresis was performed according to Laemml i (3).

Gels containing labeled products were siced with a Gilson gel sicer and counted. Non labeled gels were stained with Coomassie brilliant blue.

\section{RESILLTS}

Properties of Sp-carboxylase. When vitamin $\mathrm{K}$ hydroquinone and $\mathrm{H}^{14} \mathrm{CO}_{3}{ }^{-}$ are added to Sp-carboxylase, the carboxylation of the endogenous substrate will start without delay (Fig. 1a). The time-course of this carboxylation reaction was not affected by adding $2 \mathrm{~mm}$ of the exogenous substrate Phe-Leu-Glu-GTU-Leu (data without peptide not shown), and the reaction rate 
was constant for about $30 \mathrm{~min}$. The incorporation of ${ }^{14} \mathrm{Co}_{2}$ into the exogenous substrate lagged behind for about $30 \mathrm{~min}$, i.e. unt il about one-half of the endogenous substrate had been carboxylated. After the lagphase, all carboxylase was still firmly bound to the sepharase-beads but mevertheless, the carboxylation of exogenous substrate started and proceeded with a constent rate for more than $2 \mathrm{~h}$ (Fig. 1. A).

Fig. 1. The carboxylation of endogenows and exogenous

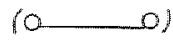
aubstrate by sp-carboxylase.

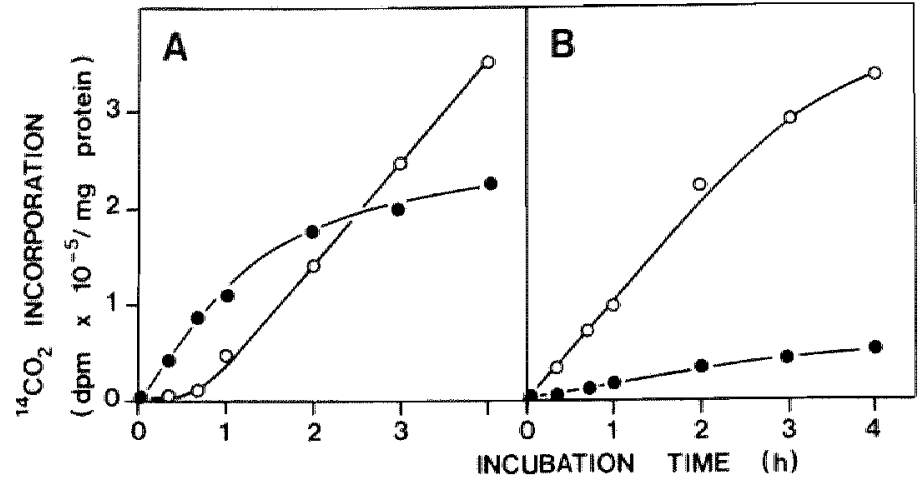

$A$, Sp-carboxylase was incubated in the presence of vitamin $\mathrm{K}$ mydroquinone, $\mathrm{H}^{14} \mathrm{CO}_{3}$ and pentapeptide and the incorporation of ${ }^{14} \mathrm{CO}_{2}$ into the varicus substrates was measured. B, Sp-carboxylase was preincubated at $25^{\circ} \mathrm{C}$ in the presence of vitamin $\mathrm{K}$ hydroquinone and nonlabeled $\mathrm{HCO}_{3}{ }^{-}$for $90 \mathrm{~min}$, washed with $0.15 \mathrm{MMaCl}$, and incubated with vitamin $\mathrm{K}$ hydroquinone, $\mathrm{H}^{14} \mathrm{CO}_{3}$ and peptide substrate as described above.

Because we also wanted to assay the carboxylation in a system that was independent of the wariable conditions induced by the preferential carboxylation of the endogenous substrate, we preincubated sp-carboxylase in the presence of vitamin $\mathrm{K}$ hydroquinone and nonlabeled $\mathrm{NaHCO}_{3}$ and in the absence of the peptide substrate for $90 \mathrm{~min}$ at $25^{\circ} \mathrm{C}$. After this period the Sepharose beads were washed and could be used for the carboxylation of the pentapeptide. Now the reaction showed no lag phase and proceeded in a linear way for more than $3 \mathrm{~h}$ (Fig. 1b). It turned out that during the preincubation no detectable amount of enzyme was lost. The preincubated Sp-carboxylase was used in all experiments mentioned below, when the vitamin k-dependent carboxylation was measured. 
Well known inhibitors and stimulators of rat liver carboxylase (4) were tested with Sp-carboxylase (Table 1). The results are similar to those found with rat carboxylase and bovine carboxylase.

Tabte I. Comparition between the vitamin K-Gependent and the t-butylhydroperonide-dependent carboxylation.

$\begin{array}{llc}\text { Addition to standerd } & \text { Vitanin K-dependent } & \text { t-butylhydroperoxide- } \\ \text { neaction mixture } & \text { carboxylation } & \text { dependent carboxylation }\end{array}$

$\begin{array}{lrr}\text { none } & 100 & 100 \\ \text { none, dithiotreitol omitted } & 26 & 3 \\ \text { chloro-K (0.1 mi) } & 30 & 8 \\ \text { warfarin (1 mM) } & 62 & 20 \\ \text { p-hydroxymercuribenzoate (1 mM) } & 4 & 0 \\ \text { pyridoxalphosphate (2 mM) } & 138 & 114 \\ \text { EOTA (2 mM) } & 102 & 104\end{array}$

A number of chemicals, known to either inbibit or stimulate the vitamin $K$-dependent carboxylation was assayed for their effect on the t-butylhydroperoxide-driwen carboxylation. In the latter case vitamin $k$ hydroquinone was replaced by $2.5 \mathrm{~mm} t$-butylhydroperoxide. The control values (100\%) were: $2300 \mathrm{dpm}$ per mg protein per min for the vitamin $\mathrm{K}$-dependent reaction and $420 \mathrm{dpm}$ per mg protein per min for the t-butylhydroperoxide-dependent reaction.

When we compared Sp-carboxylase with the vitamin $K$-dependent carboxy lase present in solubilized microsomes, we observed three differences a) Sp-carboxylase is far more active with reduced vitamin $k$ than with non reduced vitamin $K$. The activity of sp-carboxylase in the presence of vitamin $K$ or vitamin $K$ epoxide is respectively $20 \%$ and $5 \%$ of the activity observed in the presence of vitamin $k$ hydroquinone. b) The $k_{m}$ of the synthetic pentapeptide is $11 \mathrm{mM}$ in the microsomal extract and $3 \mathrm{~m}$ in Sp-carboxylase. The $\mathrm{K}_{\mathrm{m}}$ of " $\mathrm{CO}_{2}$ " is $0.2 \mathrm{mM}$ in the mincrosomal extract and 0.8 $\mathrm{mM}$ in Sp-carboxylase. c) Sp-carboxylase is more stable at elevated temperatures than carboxylase in the microsomal extract (Fig. 2 ). 
The highest activity was observed at $35^{\circ} \mathrm{C}$ and at this temperature the reaction rate was constant for more than 2 hours. When carboxylase was eluted from the Sepharose beads (see Materials and Methods) the enzyme renalned fully active at $35^{\circ} \mathrm{C}$, whereas the non-purified carboxylase in solubllized microsomes is rapidiy destroyed at this temperature.

Fig. 2. Activity of vamious aaboxylase preparations during time course atudies at $15^{\circ} \mathrm{C}\left(\mathrm{O}-25^{\circ} \mathrm{C}(\mathrm{O}-\mathrm{O}), 35^{\circ} \mathrm{C}\right.$ and 450 C (

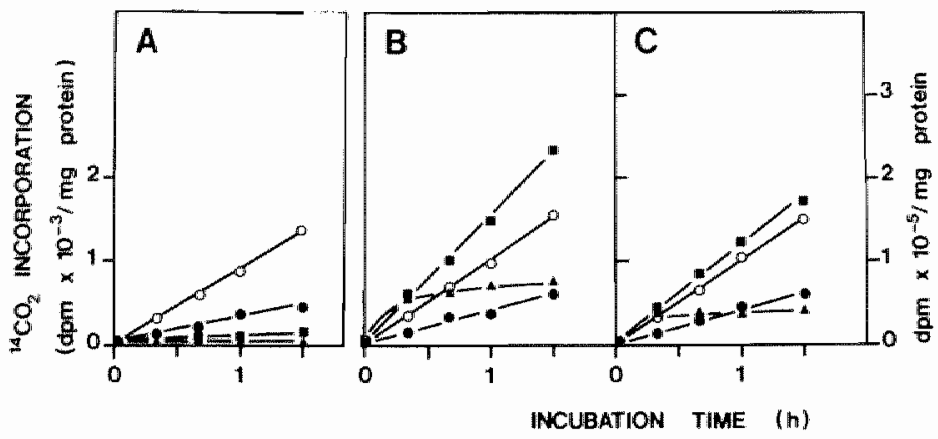

A, carboxylase in solubilized microsones; $B$, Sp-carboxylase; $C$, resolubilized carboxylase. The incubations conditions were as described in Materials and hethods.

Effect of divalent metal ions. Divalent metalions had various effects on the carboxylation reaction. Most of them were found to be inhibitory when

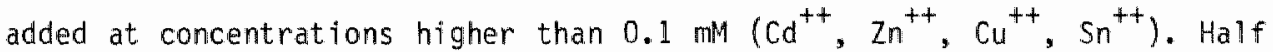
maximal inhibition with $\mathrm{Fe}^{++}$was observed at a concentration of $10 \mu \mathrm{M}$. The inhibition by $\mathrm{Fe}^{2+}$ was non competitive with the reaction components (Phe-Leu-G]u-Giu-Leu, Vitamin $\mathrm{K}$ hydroquinone, $\mathrm{NaHCO}_{3}$ and $\mathrm{O}_{2}$ ). $\mathrm{Mg}^{++}$and $\mathrm{Ba}^{++}$did not affect the carboxylation reaction at concentrations below $50 \mathrm{~mm}$, whereas $\mathrm{Ca}^{++}$and $\mathrm{Mn}^{++}$were stimulating (Fig. 3). $\mathrm{Ca}^{++}$and $\mathrm{Mn}^{++}$ians did not affect the $K_{m}$ of Phe-Leu-Glu-Glu-Leu, which is present in a suboptimal concentration in the reaction mixture. Our efforts to prepare a metal ion-dependent carboxylase with chelating agents were not succesfull (not shown). 
Rig. 3. The stimulation of the vitamin k-dependent carboxylation by $\mathrm{Ca}^{\text {t+ }}$ and $\mathrm{Mn}^{+*}$ ions.

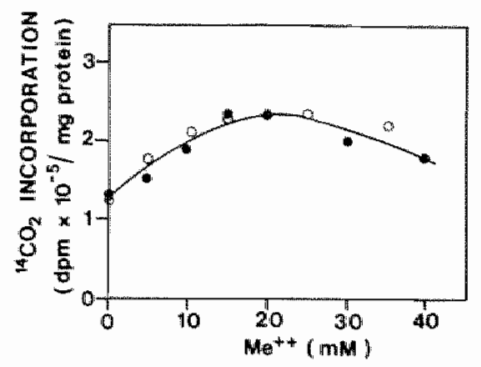

The Canboxplation of Phe-Lel-glu-Gu-Ieu was measured with sp-carboxylase for 1 th

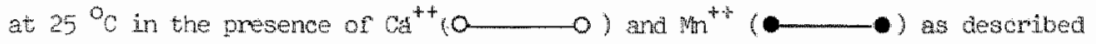
in Materials and Methods.

Effect of various scavengers and the possible involvement of a hydroperoxide intermediate in the carboxylation reaction. Radical scavengers are known inhibitors of carboxylase in the rat system. We also found inhibition by various anitoxidantia (phenol, naphtol, ethanol, vitamin $E$ ). Scavengers, which are more or less specific for. $\mathrm{OH}$ (mannitol, glucose, tryptophan), singlet $\mathrm{O}_{2}$ (histidine, azide),.$_{2} \mathrm{O}_{2}^{-}$(superoxide dismutase) and $\mathrm{H}_{2} \mathrm{O}_{2}$ (catalase), were not found to affect the carboxylation reacton at concentrations known to be effective in other systems $(5,6)$. The inhibition by peroxidases (7) could be confirmed with Sp-carboxylase. Furthermore $t$-butylhydroperoxide could replace vitamin $k$ hydroquinone in the reaction mixture, as has been reported for the rat systen (8). This t-butylhydroperoxide dependent reaction was stimulated or inhibited by the same reagents as the witamin $K$-dependent reaction (table I). A time course of the t-butylhydroperoxide-dependent carboxylation is given in fig. 4 .

The reaction velocity decreased after about $30 \mathrm{~min}$, but a second addition of t-butylhydroperoxide again stimulated the carboxylation reaction, indicating that the peroxide concentration had decreased during the first incubation. The total carboxylation after the renewed addition was less, however, $(5000 \mathrm{dpm} / \mathrm{mg})$ than after the first addition $(12.000$ $\mathrm{dpm} / \mathrm{mg})$. this may be due to inactivation of $\mathrm{sp-carboxylase} \mathrm{by}$ 
t-butylhydroperoxide. It could be demonstrated that Sp-carboxylase, incubated with $20 \mathrm{~m}$ th-butylhydroperoxide for $60 \mathrm{~min}$ and subsequently washed with buffer $A$, was completely inactive (as measured with the vitamin $K$ -dependent and t-butylhydroperoxide-dependent incorporation of $\left.\mathrm{CO}_{2}\right)$.

Fig. 4. Time course of the t-butylhydroperowide-dependent carboxylation.

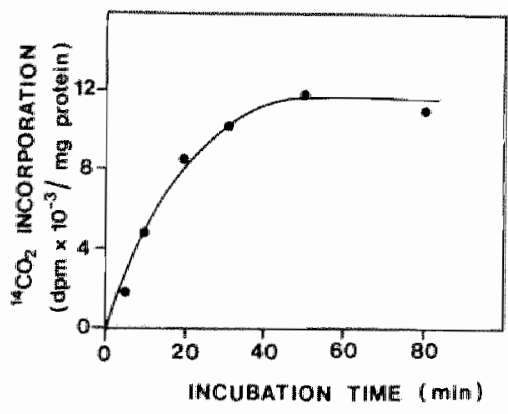

The cerboxylation was measured with Sp-carboxylase as described in Materials and Methods. VItamin $K$ hydroquinone was meplaced by $2.5 \mathrm{~m}$ t-buty]ndioperoxide.

Characterization of $5 p$-carboxylase. The protein part of $5 p$-carboxylase was eluted from the Sepahrose with $6 \mathrm{M}$ urea and $2 \%$ SDS and analyzed with the aid of SDS polycrylamide gel-electrophoresis. On these gels we observed several protein bands (fig. 5). Two major bands $\left(M_{r} 50,000\right.$ and $\left.M_{r} 30,000\right)$ are not part of the carboxylase complex, but are impurities that elute from the antibodies linked to the Sepahrose (even when no carboxylase is bound to $(t)$. Up till now we do not know which of the other proteins belang to the carboxylase complex. It seem plausible, however, that at least two different proteins are part of the complex, as two proteins $\left(M_{r} 45,000\right.$ and 30,000 ) bound ${ }^{3} \mathrm{H}$ labeled vitamin $\mathrm{K}$ (Fig. 5). The vitamin $\mathrm{K}$ binding capacity of the proteins in Sp-carboxylase which was analyzed on SDS gels and which is expressed as dpm per mg protein, was at least 50 times higher than was the binding capacity of the proteins in solubilized microsomes.

Elution of the enzyme from the solid phase. The enzyme is linked to the Sepharose via a strong antigen-antibody interaction. The antibody is covalently attached to the Sepahrose and the antigen (endogenous substrate) 


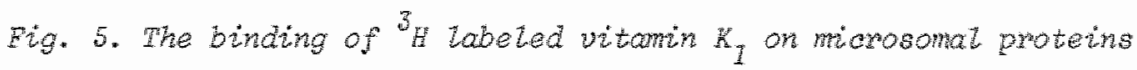
(A) and on Sp-amborylase (B) as anatyzed by sos-polyarylamide getelectrophorestis.

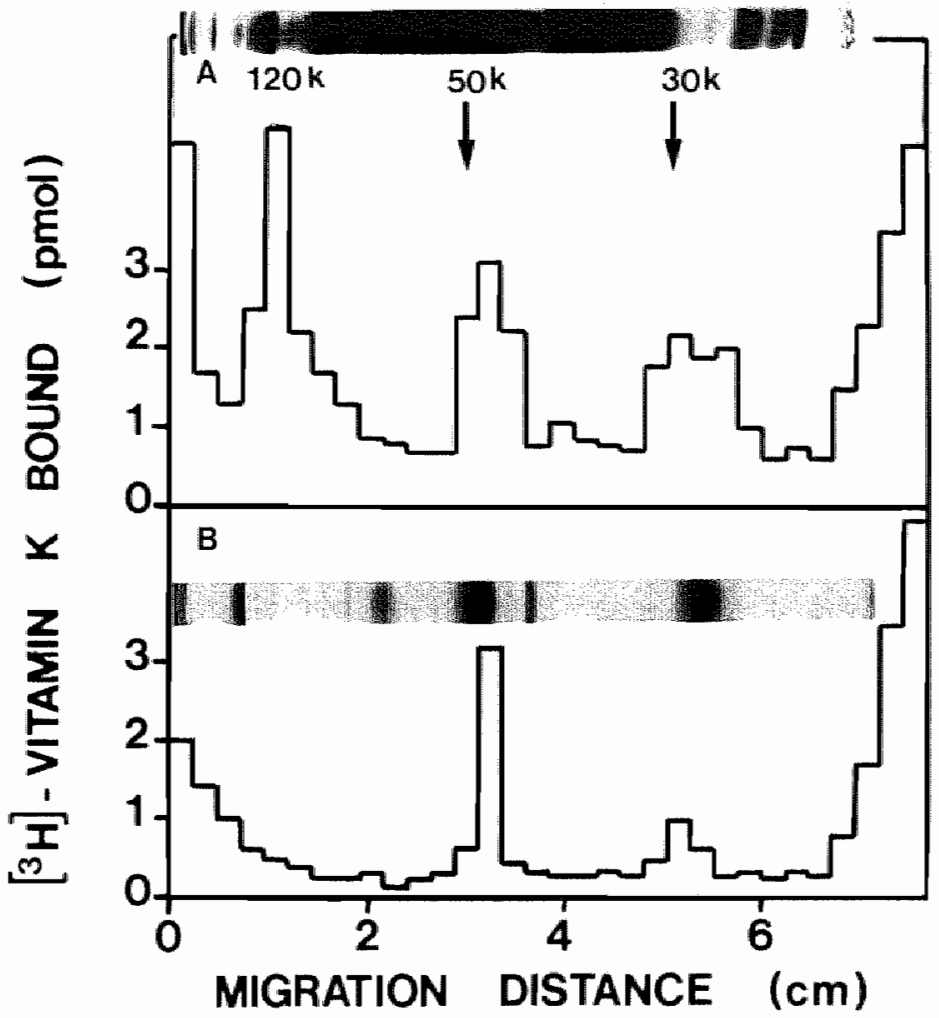

Solubilized microsomes ( $0.5 \mathrm{mg}$ of protein) and sp-carboxylase, eluted fron the solid phase with $6 \mathrm{M}$ urea and 2 SDS 10.05 mg of protein), were analyzed on SDS gels as desribed in Materials and Methods. When the gels had to be sliced for countang (see Materials and hethods) the procedure was as follows. Solubilized microsomen $10.5 \mathrm{~ms}$ of protein) and Sp-carboxylase $(0.01 \mathrm{mg}$ of protein) were incubated with $20 \mathrm{wL}$ " $\mathrm{H}$ labeled vitamin $K_{1}\left(300 \mathrm{Ci} / \mathrm{moll}\right.$ ) for 2 in at $25^{\circ} \mathrm{C}$ and dialyzed overnight against $0.1 \%$ SDS, $0.1 \mathrm{M}$ glycine and $0.05 \mathrm{M}$ Tris-HCl pH 8.0 before electrophoresis. 
is tightly complexed to the enzyme. Conventional methods for the breakage of the antigen-antibody interaction were not succesful in the resolubilization of carboxylase, because the enzyme actiwity was irreversibly lost. By having the carboxylation reaction proceed in the presence of vitamin $k$ hydroquinone and Phe-Leu-G1u-Glu-Leu (see Materials and Methods) up to $20 \%$ of the carboxylase activity could be regained in solution. In the presence of an excess of antigen (factor $x$ ) the eluted activity raised to $30 \%$. The factor $x$ could be removed from the carboxylase with the aid of DEAE Sephadex. The carboxylase preparation thus obtained had a high molecular weight $\left(M_{p} 700,000\right)$, as estimated with collum chromatography (AcA 22) and did not contain the major impurities $\left(M_{r}, 50,000\right.$ and $\left.M_{r} 30,000\right)$ present in sp-carboxylase. A further purification seems impossible without breaking the high molecular weight aggregate. Until now this could not be achieved without a substantial loss of enzyme activity.

\section{DISCUSSION}

Sp-carboxylase is strongly attached to the Sepharose beads via its endogenous substrate (a factor $X$ precursor). The endogenous substrate can still be carboxylated and it seems plausible that the substrate, is released from the carboxylating enzyme after being carboxylated. Indeed we observed that carboxylase was partly eluted from the solid phase by having the carboxylation reaction proceeded. It is not known whether al1 13 carboxylatable glutamic acid residues in the factor $x$ precursor are carboxylated. However, because the main part of carboxylase remains attached to the solid phase after carboxylation of the endogenous substrate, we thimk that the substrate is carboxylated incompletely.

A further purification could not be achieved with the carboxylase eluted from the solid phase, as this carboxylase preparation is a high molecular weight structure, which could not be cleaved without a loss of enzyme activity.

The vitamin $k$-dependent carboxylation reaction can be studied independent of the variable conditions induced by the presence of endogenous substrate by using preincubated sp-carboxylase. The carboxylation 
rate of Phe-LeU-Glu-Glu-Leu with the preincubated Sp-carboxylase is linear for at least $3 \mathrm{~h}$ and the properties of this reaction are similar to those of a non-purified microsomal preparation. Non reduced forms of vitamin $k$ however, are less active than vitamin $k$ hydroquinone, indicating that $\mathrm{Sp}$ carboxylase has a low amount of vitamin $k$ reductase. Most features of the viltamin $k$-dependent carboxylation reaction known from the rat system (such as the possible involvement of a hydroperoxide intermediate and the stimulation by some divalent metal ions), could also be demonstrated with bovine sp-carboxylase. The t-butylhydroperoxide-dependent carboxylation could also be demonstrated with $\mathrm{Sp-carboxylase}$ and the requirements for this type of carbaxylation were similar to those for the vitamin $k$ dependent carboxylation. This finding supports the idea that a hydroperoxide intermediate of vitamin $K$ is driving the carboxylation reaction (7). As has been stated already by Larson and Suttie (9) the stimulation by metal ions is probably due to an unknown activation of the in vitro system and not to a specific metal ion requirement of the enzyme. The strong inhibition by $\mathrm{Fe}^{2+}$ ions can readily be explained by assuming that $\mathrm{Fe}^{2+}$ acts as a peroxidase in our system. Fvidence for this hypothesis will be presented in chapter 8 .

When the protein part of Sp-carboxylase was analyzed with SDS polyacrylamide gelelectrophoresis several protein bands were observed. Two proteins were binding ${ }^{3} H$ llabeled vitamin $K\left(M_{r} 45000\right.$ and $\left.M_{r} 30000\right)$. It is not known if these are the only proteins required for the proper function of carboxylase. A further characterization of carboxylase is hampered by the fact that a further purification of the active enzyme cannot be achieved at this moment. 
De Metz, M., Vemeer, C., Soute, B.A.M. and Hernker, H.C. (1980) in: Vitamin $K$ metabolism and vitamin $K$ dependent proteins (Suttie, L.M. ed.), University Park Press, Raltimore, 560-570

2. Lowry, 0.H., Rosebrough, N.J., Favor, A.L. and Randa11, R.J. (1951) J.Biol.chem. 193, 265-275

3. Laemenli, V.K. (1970), Nature 227, 680-685

4. Suttie,J.W. (1980) C.R.C. Crit.Rev.Biochem. 8, 191-223

5. Kellogg, E.W. and Fridovich, I. (1977) J.Biol.Chem. 252, 6721-6728

6. McPhai1, L.C., Ambrusso, D.R., Pabst, H.J. and Johnston, R.R. (1979) in: Biochemical and Clinical Aspects of Oxygen (Laughey, W.S. ed.) pp. 709-723. Academic Press, New York.

7. Larson, A.E. and suttie, J.W. (1978) Proc.Natl.Acad.Sci.USA 75, 5413$-5416$

8. Suttie, J.W., Larson, A.E., Canfield, L.M. and Carlisle, T.L. (1978) Fed.Proc. 37, 2605-2609

9. Larson, A.E. and Suttie, J.W. (1980) FEBS Lett. 118, 95-98 
CHAPTER 6

IDENTIFICATION OF PHOSPHOLIPID AS AN ESSENTIAL PART OF BOVINE VITAMIN K-DEPENDENT CARBOXYLASE.

This work has been published,

De Metz, M., Vermeer, C., Soute, B.A.M. and Hemker, H.C. (1981) J.Biol. Chem. $256,10843-10846$ 
SUMMARY

Vitamin $k$-dependent carboxylase from bovine liver contains phospholipid (primarily phosphatidylcholine). Which is essential for its in vitro activity. Sepharose-bound carboxylase can be depleted of phospholipids, either by washing the enzyme with detergents or by phospholipase treatment. The enzyme can be reconstituted by adding mixed micelles of phosphatidylcholine and cholate to the Sepahrose-bound proteins.

\section{INTRODUCTION}

Vitamin $k$ is required for the post-translational carboxylation of a number of glutamic acid residues in many proteins. Several reviews about this reaction have been published recently (1-3). The carboxylating enzyme system (carboxylase) is obtatined from the rough microsomal fraction of hepatic cells (4) and can be extracted therefrom with detergents or bile salts (5). Until now, the purification of carboxylase from this extract has not been accomplished, mainly because the enzyme activity is lost during the purification procedure $(5,6)$. It has been suggested therefore, that the enzyme is constituted of at least two components, both of which are required for the carboxylation reaction (7).

We have developed a saluble carboxylating enzyme system from the liver of warfarin-treated cows. This bovine carboxylase was purified more than 100-fold by immunospecific adsorption to antibodies against its endogenous substrate (chapter 4, 8). In this chapter we present evidence that phospholipids are an essential part of this partly purified carboxylase.

MATERIALS MND: METHODS

Materia1s. Buffer A: $0.15 \mathrm{M} \mathrm{NaCl,} 20 \mathrm{mM}$ Tris-HCl, pH 7.5. Triton X-100, cholate, dithiothreitol and bowine albumin (essentially fatty acid free), PI and SPH were obtained from sigma and vitamin $K_{1}$ from Hoffmann-La 
Roche. $\mathrm{NaH}^{14} \mathrm{CO}_{3}(40 \mathrm{mCl} / \mathrm{mmol})$ and Aquasol-2 were purchased from New England Nuclear and the synthetic pentapeptide Phe-Leu-Glu-Glu-Leu from Vega Fox. Phaspholipase $A_{2}$ (from Naja naja), phospholipase C (from Bacillus cereus) and phospholipase D (from Savoy cabbage) were prepared as described by Zwaal et al. (9). PC was prepared from egg yolk (10) and used for the preparation of phosphatidic acid, $P S, P E$ and $P G$ (11). Diglycerides were prepared from PC by hydrolysis with phospholipase $C$ and $1 y$ so-PC and free fatty acids by hydrolysis with phospholipase $A_{2}$. The phospholipids were added to the various phospholipases in the form of mixed micelles, $P C$ and cholate being present in a $1: 1$ ratio $(w / w)$. The micelles were prepared by evaporating the solvent from the various (phospho)lipids and resuspending the residue in buffer $A$ containing Triton $X-100$ or cholate as indicated. The suspension was sonicated subsequently until a clear solution was abtained. During the phospholipase treatment the reaction conditions were as described below. The hydrolysis products were separated with the ald of silica thin layer chramatography, using a mobile phase containing chloroform: methanol: $\mathrm{NH}_{4} \mathrm{OH}$ : water in a ratio of $90: 54: 5.5: 5.5$ (v/v). The lipids were extracted from the silica with a mixture containing equal volumes of chloroform and ethanol.

Preparation of carboxylase. Carboxylase was prepared and solubilized from the microsomal fraction of the livers of warfarin-treated cows and adsorbed from the solution with antifactor $X$-Sepharose (chapter 4). This solid-phase carboxylase (Sp-carboxylase) was used for most of the experiments, and contained $150 \mu \mathrm{g}$ of protein per ml Sepharose slurry.

Measurement of carboxylase activity. The vitamin $K$-dependent incorporation of ${ }^{14} \mathrm{CO}_{2}$ was measured by incubating reaction mixtures $(0.25 \mathrm{ml})$ containing either $0.1 \mathrm{ml}$ of $\mathrm{Sp-carbaxylase}$ or $10 \mu \mathrm{g}$ of re-solubilized carboxylase and $2 \mathrm{mM}$ dithriothreitol, $0.2 \mathrm{mM}$ witamin $\mathrm{K}$ hydroquinone, $20 \mu \mathrm{Ci} \mathrm{NaH}^{14} \mathrm{CO}_{3}$ and buffer $\mathrm{A}$ at $25^{\circ} \mathrm{C}$. When the carboxylation of exogenous substrate was measured, Sp-carboxylase was preincubated in the presence of non-labeled $\mathrm{NaHCO}_{3}$ (instead of $\mathrm{NaH}^{14} \mathrm{CO}_{3}$ ) for $90 \mathrm{~min}$, washed with buffer $\mathrm{A}$ and then assayed as described above. The reaction was stopped with $2 \mathrm{ml}$ icecold trichloroacetic acid $(10 \% w / w)$ and the precipitates were washed and counted in Aquasol-2 in a Packard Tri-Carb scintillation counter. The 
trichloroacetic acid supernatants were degassed at elevated termperatures before counting

Treatment with detergents and phospholipases. For the treatment of Sp-carboxylase with detergents, $0.5 \mathrm{ml}$ of the sepahrose-bound enzyme was incubated for 30 min at $25^{\circ} \mathrm{C}$ in $1.5 \mathrm{ml}$ of buffer $A$ and detergents as indicated. The sepharose beads were washed subsequently with 20 ml of buffer $A$ containing $2 \mathrm{mM}$ EDTA and $2 \mathrm{mg} / \mathrm{ml}$ of bovine albumin and once more with $20 \mathrm{ml}$ of buffer $A$ containing 0.5 mM EDTA. Incubations with phosphol lpase $A_{2}$ and phospholipase $C$ were carried out in buffer $A$ containing 10

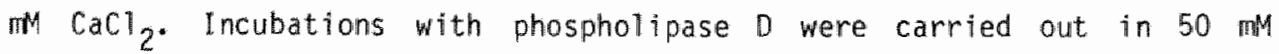
sodiumacetate, $30 \mathrm{mM} \mathrm{MaCl}, 50 \mathrm{mH} \mathrm{CaCl}$, $\mathrm{pH}$ 6.3. Sp-carboxylase (0.5 ml) was supplemented with $1.5 \mathrm{ml}$ of buffer A containing $5 \mathrm{I}$.U. of phospholipase and incubated for $1 \mathrm{~h}$ at $37^{\circ} \mathrm{C}$. After the incubation the solid-phase enzyme was washed in a manner similar to that used after the treatment with detergents.

Phospholipid and protein determination. Phospholipids were extracted from carboxylase according to the method of Bligh and Dyer (12), separated by two-dimensional thin layer chromatography (13), and quantitated by determining the amount of phosphate present in each spot (14). Protein concentrations were determimed according to Lowry et a1. (15). The protein content of Sp-carboxylase was measured after eluting the sepharose beads with 6 M urea in $2 \%$ sodium dodecyl sulphate.

\section{RESULTS}

Phospholipid content of Sp-carboxylase. Sp-carboxylase is prepared by adsorbing solubilized microsomes anto antifactor $X$-Sepharose. The factor $x$-precursors present in the soluble preparation (chapter 4,8 ) bind to the antibodies, and because most of the carboxylase is tightly complexed to these factor $x$-precursors, the enzyme-substrate complex is bound to the sepharose beads. The enzyme preparation thus obtained contained $72 \%$ protein and $28 \%$ phospholipid. With the aid of two-dimensional thin layer chromatography, more than 95\% of these phospholipids could be identified as PC. 
Effect of detergents of Sp-carboxylase. The surfactants Triton $x-100$, chollate and deaxycholate, which are commonly used for the extraction of carboxylase from the microsomal membranes, strongly intibited sp-carboxylase. This inhibition could be prewented by adding a crude extract of microsomal phospholipids to the insolubilized enzyme. Since the bulk of detergent is easily separated from Sp-carboxylase by washing the sepharose beads, we were able to demonstrate the reversibility of the detergentinduced inactiwation (Table 1).

At low detergent concentrations, a substantial loss of enzyme activity was abserved, but after washing the Sepahrose beads with a buffer containing 1 IMM EDTA, much of the carboxylating activity was restored and

Table 1. The effect of detergents on the carboxylation rate of

$$
\text { Phe-teu-Gu-Gu-Leu. }
$$

One $\mathrm{ml}$ of Sp-carboxylase was incubated with detergent (as indicated) for $10 \mathrm{mLn}$ at $30{ }^{\circ} \mathrm{C}$. The Sepharose beads were washed as described under Materials and Methods, and the carboxylase activity was measured and expressed as a percentage of the control value $(115,000 \mathrm{dpm}$ per ref of protein). The concentration of exogenous phospholipids was $1 \mathrm{mg} / \mathrm{ml}$, and they were added to the enzyme as mixed micelles of phospholipida and cholate. In these micelies the ratio of phospholipid:cholate was $1: 1$ ( $w / w)$. The incorporation of ${ }^{14} \mathrm{CO}_{2}$ was assessed after $1 \mathrm{~h}$ at $25^{\circ} \mathrm{C}$.

\begin{tabular}{|c|c|c|c|c|}
\hline Before washing & \multirow{3}{*}{ Activity } & \multicolumn{3}{|c|}{ After washing } \\
\hline \multirow{2}{*}{ Detergent added } & & \multirow{2}{*}{$\begin{array}{l}\text { Phospho- } \\
\text { lipia/protain } \\
\text { ratio } \\
(w / w)\end{array}$} & \multicolumn{2}{|c|}{ Carboxylase activity } \\
\hline & & & $\begin{array}{l}\text { Minus } \\
\text { phospho- } \\
\text { Lupids }\end{array}$ & $\begin{array}{l}\text { Plus phos- } \\
\text { polipias }\end{array}$ \\
\hline & \multicolumn{2}{|l|}{ of controll } & \multicolumn{2}{|c|}{ of control } \\
\hline None & 100 & 0.40 & 105 & 115 \\
\hline Cholate $(0.1 \%)$ & 50 & 0.38 & 95 & 120 \\
\hline Cholate $(0.5 \%)$ & 3 & 0.06 & 12 & 65 \\
\hline Deoxycholate (0.12) & 12 & 0.25 & 62 & 84 \\
\hline Deoxucholate $(0.5 \%)$ & 2 & 0.04 & 10 & 41 \\
\hline Traton $x-100(0.02 \%)$ & 30 & 0.30 & 70 & 90 \\
\hline Traton $x-100(0.1 \%)$ & 1 & 0.02 & 16 & 42 \\
\hline
\end{tabular}


no significant loss of phospholipids could be measured. At higher detergent concentrations, however, nearly all carboxylase activity was lost. After the washing procedure about $90 \%$ of the phospholipids had been removed and only 10-15\% of the enzyme activity was left. After recombining the washed Sepharose beads with microsamal phospholipids about one-half of the original carboxylase activity could be regained.

The effect of phospholipases on Sp-carboxylase. Sp-carboxylase was incubated in the presence of a number of phospholipases, which were subsequently removed by washing the solid-phase enzyme as described in Materials and Methods. In all cases the carboxylating activity was essentfally destroyed (Table 2), which indicates that either carboxylase requires intact phospholpids or the degradation products of the endogenous phospholipids (almost exclusively PC) act as inhibitors of carboxylase.

Table 2. The effect of phosphotipases on the carboxylation rate of Phe-Leu-Giu-Gitu-Leu.

One ml of Sp-oarboxylase was incubated with $1 \mathrm{mg}$ of phospholipase for $1 \mathrm{~h}$ at $30^{\circ} \mathrm{C}$. The Sepharose beads were washed as described under "Materials and Methods", and the carboxylase activity was measured and expressed as a percentage of the control value $(115,000$ dpm per mog protein). The concentration of exogenous phospholipids was $1 \mathrm{mg} / \mathrm{ml}$, and they were added to the enzyme as mixed micelles of phospholipids and cholate as described in the legend to Treble I. The incorporation of ${ }^{14} \mathrm{CO}_{2}$ was assessed after $1 \mathrm{~h}$ at $25^{\circ} \mathrm{C}$.

Before wasthing

\begin{tabular}{|c|c|c|c|c|}
\hline \multirow{2}{*}{$\begin{array}{l}\text { Phospholipase } \\
\text { used }\end{array}$} & \multirow{2}{*}{$\begin{array}{c}\text { Carboxylase } \\
\text { activity }\end{array}$} & \multirow{2}{*}{$\begin{array}{l}\text { Phospho- } \\
\text { lipid/protein } \\
\text { ratio } \\
\text { (w/w) }\end{array}$} & \multicolumn{2}{|c|}{ Carboxylase activity } \\
\hline & & & $\begin{array}{l}\text { Minus } \\
\text { phosoho- } \\
\text { lipids }\end{array}$ & $\begin{array}{l}\text { Plus phos- } \\
\text { pholipids }\end{array}$ \\
\hline \multicolumn{3}{|c|}{ of control } & \multicolumn{2}{|c|}{ of control } \\
\hline Phospholipase $A_{2}$ & $a$ & 0.01 & 4 & 40 \\
\hline Phospholipase c & 1 & 0.06 & 6 & 66 \\
\hline Phospholipase D & 9 & 0.29 & 1 & 22 \\
\hline
\end{tabular}


Big. 1. Inhibition of Sp-carboxylase by phosphotipid degnadation produets.

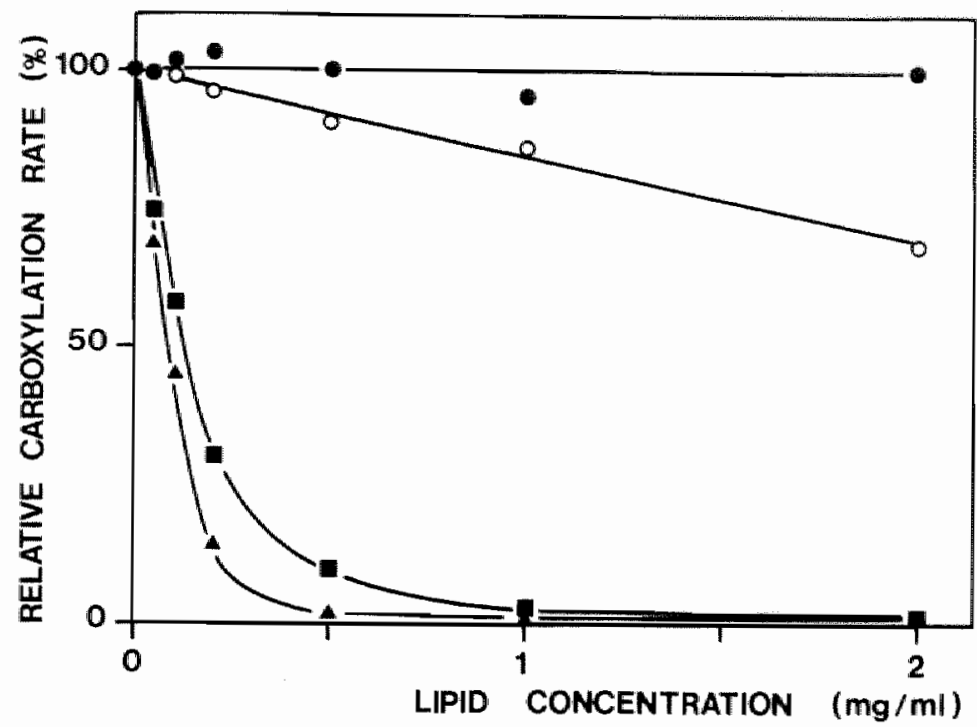

Sp-carboxylase was supplemented with mixed micelies of cholate and either lyso-PC ( $\longrightarrow$ ), diglycerides ( $0 \longrightarrow 0)$, phosphatidic acia (-—), or free fatt acids $(\leadsto)$ in a $1: 1$ ratio $(w / w)$. Subsequentily, the carboxylase activity was measured in the presence of $1 \mathrm{mM}$ EDTA. The incorporation of ${ }^{14} \mathrm{CO}_{2}$ was assessed after 1 h at $25^{\circ} \mathrm{C}$.

The influence of the various split products of $P C$ was therefore assessed. It appeared that the water-soluble chol ine and cholinephosphate (which are formed by phospholipase $D$ and $C$, respectively) are readily washed out from the Sepahrose beads. Free fatty acids and phosphatidic acid (formed by phospholipase $A_{2}$ and $D$ respectively) are strong inhibitors of carboxylase (Fig. 1), whereas lyso-PC and diglycerides (resulting from the action of phospholipase $A_{2}$ and $C$ respectively) hardly influence the vitamin $K$ dependent carboxylation. Moreover, when using a washing buffer containing bovine albumin and EDTA, the free fatty acids (as well as 1yso-PC) were efficiently removed from the solid-phase enzyme. No washing procedure could be developed, however, by which any carboxylase activity was recovered. On the other hand, in all cases the enzyme activity could be partially restored by adding crude microsomal phospholipids. The recovery was about $50 \%$ except in the case of phospholipase D, where one of the split products 
(phosphatidic acid) could not be completely washed out. Since phosphatidic acid is a strong inhibltor of carboxylase (fig. 1), this low recovery of carboyylase activity is to be expected in this case.

Beconsttution of phospholipid-depleted sp-carboxylase with purified phospholipids. Sp-carboxylase was depleted from its endogenous phospholipids by incubation with phospholipase $C$ and washed as described above. A number of purified phospholipids was assayed subsequently for their ability to reconstitute the active enzyme (Table 3 ).

Table 3. The deperdance of sp-carboxylase on pumfed phosphotipids. Phospholipid-depleted Sp-carboxylase was prepared with the aid of phospholipase $c$ as described in the legend to Table II. The various phospholipids were added to the enzyne ass mixed micelleg with cholate in a $1: 1 \mathrm{ratio}(\mathrm{w} / \mathrm{w})$. The final phospholipid concentration was $1 \mathrm{mg} / \mathrm{ml}$. The results are exuressed as a percentage of the control value $(115,000$ dpm per ing of protein). The incorporation of ${ }^{14} \mathrm{CO}_{2}$ was assessed after $1 \mathrm{~h}$ at $25^{\circ} \mathrm{C}$.

\begin{tabular}{|c|c|c|}
\hline \multirow[b]{2}{*}{ Phospholipid added } & \multicolumn{2}{|c|}{ Carborylase activity in } \\
\hline & Sp-carboxylase & $\begin{array}{c}\text { Thospholipid-depleted } \\
\text { Sp-carboxylase }\end{array}$ \\
\hline & \multicolumn{2}{|c|}{ of control } \\
\hline None & 100 & 5 \\
\hline Crude microsonal extract & 104 & 70 \\
\hline Phosphatidylcholine & 110 & 84 \\
\hline Lyso-phosphatidylcholine & 98 & 77 \\
\hline Sphingonyelin & 90 & 50 \\
\hline Mosphat lay lethano lamine & 50 & 19 \\
\hline Prosphatidylinositol & 3 & 0 \\
\hline Phosphatidylserine & 2 & 0 \\
\hline Phosphatidylgelycenol & 2 & 0 \\
\hline Phosplatidio acid & 4 & 0 \\
\hline
\end{tabular}

The neutral phospholipids SPH, PC, PE and SPH, as well as lyso-PC (the splitproduct that is formed when $P C$ is digested with phospholipase $A_{2}$ l were able to partially restore the activity of phospholipid-depleted carboxy1ase. A maximal effect was obtained when the phospholipids were added in a 
concentration of $0.5-2 \mathrm{mg} / \mathrm{ml}$ as mixed micelles with cholate. PC was the phospholipid most effective in restoring the enzyme activity (up to $84{ }^{2}$ ). whereas mixtures of $P C$ and other phospholipids induced a less marked stimulation (data not shown). Negatively charged phospholipids such as PI or PG as well as phosphatidic acid did not restore any carboxylating activity. On the other hand, when added to the phospholipid-containing native enzyme, these negatively charged phospholipids strongly inhibited carboxylase. Most probably this inhibition is caused by a rapid exchange between the phospholipids in carboxylase and those in the added micelles. The presence of cholate does not seem to be an absolute requirement for the enzyme, since the removal of cholate by dialysis had no effect on the activity of the reconstituted enzyme preparation.

\section{DISCUSSION}

Sp-carboxylase is more than 100-fold purified as compared to a microsomal suspension and its properties are not very different from the latter (chapter 5). It was, however, inhibited by low concentrations of non-ionic detergents.

Analysis of the Sepharose-bound enzyme showed that it contains about $30 \%(w / w)$ phospholipids (almost exclusively $P C$ ). When we removed the phospholipid moiety, either by washing carboxylase with detergents or by destroying the phospholipids with various phospholipases, the carboxylase activity had disappeared. It could be restored by addding certain exogenous phospholipids in the form of mixed micelles, with cholate present in $1: 1$ ratio $(v / v)$. Vesicles of phospholipids alone were not effective in this respect, probably because in the absence of detergent there is no transfer of phospholipids from the wesicles to the sepharose-bound proteins. PC turned out to be the most effective in restoring carboxylase activity. This is in agreement with our observation that the natural phospholipid present in Sp-carboxylase is PC. When analyzed by SDS gel electrophoresis, Sp-carboxylase contained several bands (chapter 5) and it is not known whether all these proteins are required for carboxylase activity. The proteins present at this stage of purification are tightly complexed, however, and we have not succeeded in isolating the various components 
without a complete loss of activity. Whether all these proteins require phospholipid for their proper function cannot be conluded therefore.

When 1 mb EDTA was present in the buffers during the separation of the enzyme proteins and phospholipids and during their reconstitution, the recovery of active carboxylase could be greatly improved. As it is well known (16) that integral merbrane proteins may aggregate upon removal of their phospholipids, the effect of EDTA might be a prevention of irreversible aggregation or denaturation of carboxylase when the latter is depleted of phaspholipids.

The fact that phospholipids are an integral part of carboxylase may have implications for the purification of the enzyme. Up to now, several investigators $(5,6)$ have tried to purify carboxylase, but after fractionating the enzyme in a number of ways they observed that it had lost its biological activity. One of the possible explanations for this phenomenon might be that during the fractionation procedures the proteins of the enzyme complex are separated from the phospholipid moiety. In order to exclude this pitfall, it seems advisable to add mixed micelles of PC and cholate after each purification step to the fraction when they are assayed for carboxylase activity.

The abbreviations used are: PI, phosphatidylinositol; PC, phosphatidylcholine; $P S$, phosphatidylserine; $P E$, phosphatidylethanolamine; $P G$, phosphatidylglycerol; SPH, sphingomyel in

\section{REFERENCES}

1. Stenf10, J., and Suttie, J.W. (1977) Ann.Rev.Biochem. 46, 157-172

2. 01 son, R.E. and Suttie, J.W. (1978) Vitam.Horm. 35, 59-172

3. Suttie, J.W. (1980) C.R.C. Crit.Rev.Biochem. 8, 191-223

4. Helgel and, L. (1977) Biochim. Biophys. Acta 499, 181-193

5. Johnson, P.C. (1980) Methods Enzymol. 67, 165-180 
6. Wallim, R., Canfield, L.M., Sinsky, T.A. and Suttie, J.W. (1980) in Vitamin $K$ metabolsim and vitamin $K$-dependent proteins (Suttie, J.W. ed.) pp. 490-499, University Park Press, Baltimore

7. Price, J.A., Bartels, W.L., Chiu, A., Delaney, R., and Johnson, B.C. (1980) J.Biol.Chem. 255, 1808-1811

8. De Metz, M., Vemeer, C., Soute, B.A.M., van Scharrenburg, G.J.M., Slotboom, A.J. and Hemker, H.C. (1981) FEBS Letters 123, 215-218

9. Zwaal, R.F.A., Roellofsen, B., Comfurius, P. and van Deenen, L.L.M. (1975) Biochim. Biophys. Acta 406, 83-96

10. Singleton, W.S., Gray, M.S., Brown, N.L. and White, J.L. (1965) J.Am. 0 il Chem. Soc. 42, 53-56

11. Comfurius, P. and Zwaal, R.F.A. (1977) Biachim.Biophys. Acta 488, 36-42

12. Bligh, E.G. and Dyer, W.J. (1959) Can.J.Biochem.Physiol. 39, 911-917

13. Broekhuijse, R.M. (1969) Clin.Chim.Acta 23, 457-461

14. Chen, P.S., Toribara, T.Y. and Warner, M. (1965) Anal.Chem.28, 17561758

15. Lowry, O.M., Rosebrough, N.J., Farr, A.L. and Randall, R.J. (1951) J.Biol.Chem. 193, 265-275

16. Helenius, A. and Simons, K. (1975) Biochim.Biophys. Acta 415, 29-79 

CHAPTER 7

THE INHIBITION OF VITAMIN K-DEPENDENT CARBOXYLASE BY CYANIDE

This work has been published,

M. de Metz, B.A.M. Soute, H.C. Hemker and C. Vermeer, FEBS Lett.137, 253-256 
The vitamin $k$-dependent carboxylation and the t-butylhydroperaxidedependent carboxylation are inhibited by cyanide, whereas the epoxidation of vitamin $k$ hydroquinone is not inhibited. The inhibition was non-linear and competitive with $\mathrm{CO}_{2}$. Haem could not be detected in $5 p$-carboxylase.

\section{INTRODUCTIOM}

The formation of $Y$-carboxyglutamic acid residues from glutamic acid residues is a $v$ itamin $k$-dependent carboxylation reaction. The reaction has been demonstrated in various species and tissues $(1,2)$, but the most extensive studies have been performed in the microsomal fraction of rat liver. It is generally assumed that the carboxylation reaction is coupled to the epoxidation of reduced vitamin $k(3,4)$, but the reaction mechanism is still unclear. The purification of the carboxylating enzyme (carboxylase) from rat. liver seems to be difficult and has not been reported until now. The possible involvement of other cofactors, such as haem groups (5-7) is therefore still a matter of dispute. The main argument for the involvement of haem in the carboxylation reaction was the obserwation that cyanide inhibits rat carboxylase $(5,8)$. This inhibition has not been further analyzed, however, whereas other common haem ligands such as azide and carbon monoxide do not inhibit the vitamin $K$-dependent carboxylation (1).

We have developed a carboxylating enzyme system from the livers of warfarin-treated cows and obtained a 100-fold purification of the microsonal enzyme by immunospecific adsorption onto antibodies against the endogenous substrate $(9$, chapter 4$)$. This partly purified enzyme preparation is attached to sepharose beads and is called sollid phase carboxylase (Sp-carboxylase). The enzymatic activity of $5 p$-carboxylase is strictly dependent on the presence of phospholipids and in the presence of an excess of exogenous substrate (Phe-Leu-Glu-Glu-Leu), the carboxylation rate was constant for at least $3 \mathrm{~h}$ at $25^{\circ} \mathrm{C}(10$, chapter 5 , chapter 6$)$. In this chapter we describe the results of some more detailed inwestigations concerning the inhibition of the Sp-carboxylase catalyzed reaction by NaCN. 
Unless indicated otherwise, all chemicals were from Merck. All buffers were made free of $\mathrm{CO}_{2}$ by boiling and flushing with nitrogen gas.

One year old cows were treated with warfarin (Sigma) during 1 week (10 $\mathrm{mg} / \mathrm{kg}$ daily) and Sp-carboxylase was prepared from the livers of these cows (chapter 4). The vitamin $\mathrm{k}$-dependent incorporation of ${ }^{14} \mathrm{CO}_{2}$ was performed in reaction mixtures $(0.25 \mathrm{ml})$, containing $0.1 \mathrm{ml}$ Sp-carboxylase slurry $(80$ yg of protein), $150 \mathrm{mH} \mathrm{NaCl}, 50 \mathrm{mM}$ Tris-acetate (pH 7.0), $2 \mathrm{mM}$ Phe-Leu-Glu-Glu-Leu (Vega Fox), 2 mM dithiothreitol (Sigma), 0,2 mM EDTA, $20 \mu \mathrm{Ci} \mathrm{NaH}{ }^{14} \mathrm{CO}_{3}$ (New England Nuclear, $40 \mathrm{Ci} / \mathrm{mol}$ ) and $0.2 \mathrm{mM}$ vitamin $\mathrm{K}$ hydroquinone, which was added in the form of mixed micelles with phosphatidylcholine and Triton $x-100$ (chapter 6,10 ). The reaction mixtures were incubated for $90 \mathrm{~min}$ at $25^{\circ} \mathrm{C}$ and the reaction was stopped by adding $2 \mathrm{ml}$ icecold trichloroacetic acid $(10 \% \mathrm{w} / \mathrm{w})$. The supernatants were degassed at $80^{\circ} \mathrm{C}$ and counted. Counting was performed in a Packard Tricarb scintillation counter using picofluor-15 (Packard) as a scintillation liquid. The vitamin $K$-dependent carboxylation is expressed as the amount of $\mathrm{CO}_{2}$ (nmol) incorporated into Phe-Leu-Glu-Glu-Leu per mg of Sepharose-bound protein and was performed with preincubated Sp-carboxylase (chapter 5 ).

The $t$-butylhydroperoxide-driven carboxylation was measured under similar conditions as described for the vitamin $k$-dependent reaction, except for the fact that t-butylhydroperoxide (5 mM) was added instead of vitamin $k$ hydroquinone. The t-butylhydroperoxide-dependent carboxylation is expressed as the total amount of ${ }^{14} \mathrm{CO}_{2}$ incorporated per $\mathrm{mg}$ of protein.

Experiments in which we checked the eventual incorporation of ${ }^{14} \mathrm{CN}^{-}$ were performed in $\mathrm{CO}_{2}$-free buffers under similar conditions as clescribed for the carboxylation reaction except for the fact that $100 \mathrm{\mu Ci} \mathrm{Na}{ }^{14} \mathrm{CN}$ (New England Nuclear, $50 \mathrm{Ci} / \mathrm{mol}$ ) was added instead of $\mathrm{NaH}^{14} \mathrm{CO}_{3}$. The reaction was stopped by adding $100 \mathrm{mM}$ non-labeled $\mathrm{NaCN}$ and non-bound label was removed by dialysis. The low molecular weight Phe-Leu-Glu-Glu-Leu (and carboxylated product) was bound to DEAE Sephadex (Pharmacia) before dialysis.

Vitamin $k$ epoxide was determined by extracting the reaction mixtures with isoproponal/hexane and analyzing the extract with the aid of high performance 1 iquid chromatography (chapter 2, 11). 
Bowine vitamin $K$-dependent carboxylase was inhibited by NaCN in the solubilized fificrosomal fraction as well as in Sp-carboxylase. The nature of the cyanide inhibition was studied only in the more purified system. In dose-response studies in which the carboxylation reaction was performed at varlous $\mathrm{MaCN}$ concentrations, we observed a parabolic relation between the HaCN concentration and the inversed reaction rate (fig 1 ), indicating that the intibition is of the non-linear type (12).

Fig. 1. The inhibition of Sp-carbaxylase by NacN.

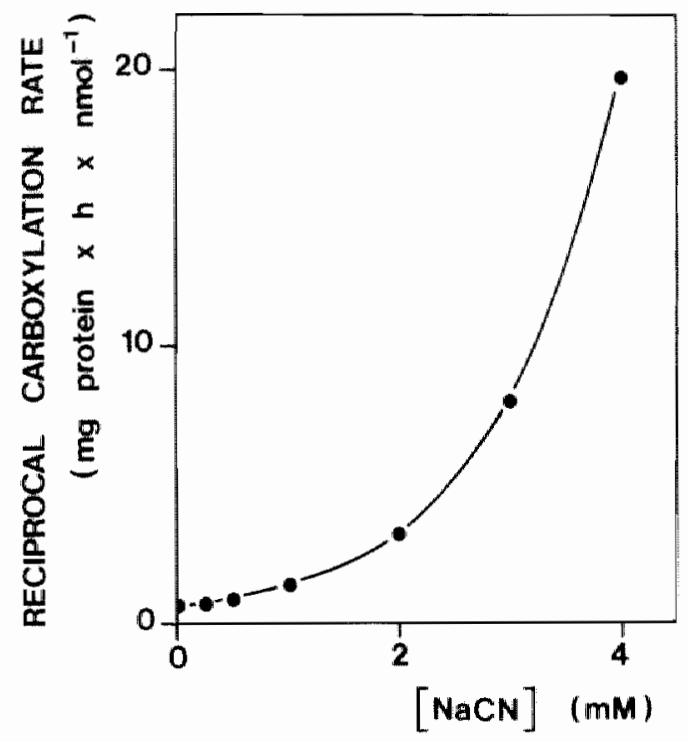

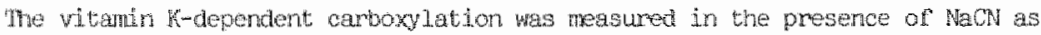

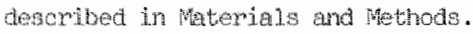

Fifty percent inhibition was obtained at a cyanide concentration of 1 m. When t-butylhydroperoxide was used as a ccenzyme for Sp-carboxylase instead of $v i t a m i n k$ hydroquinone(chapter 5), the carboxylation reaction was 28,000 dpm per mg protein per hour, which is about $10 \%$ of its normal rate. In this system the inhibition of the carboxylation occurred at similar $\mathbb{N a C N}$ concentrations as in the vitamin $k$-dependent reaction. We also found the 
cyanide inhibition to be reversible. After incubation of Sp-carboxylase with $100 \mathrm{mM} \mathrm{NaCN}$ for I h at $25^{\circ} \mathrm{C}$, the enzyme activity could be restored up to $80 \%$ by subsequent dialysis.

In order to find out, whether the inhibition by cyanide could be counteracted by increasing the concentration of one of the participants of the carboxylation reaction, we varied the concentrations of exogenous substrate, vitamin $\mathrm{K}$ hydroquinone, $\mathrm{O}_{2}$ and $\mathrm{CO}_{2}$, whereas the cyanide concentration was kept constant. These experiments were performed at $0,25,1$ and $2 \mathrm{~mm}$ $\mathrm{NaCN}$ and it resulted, that the cyanide was competitive with $\mathrm{CO}_{2}$ (fig 2).

Fig. 2. Lineweaver-Burk plots of the vitamin K-dependent incorporation of ${ }^{14} \mathrm{CO}_{2}$ at various NaCN concentrations.

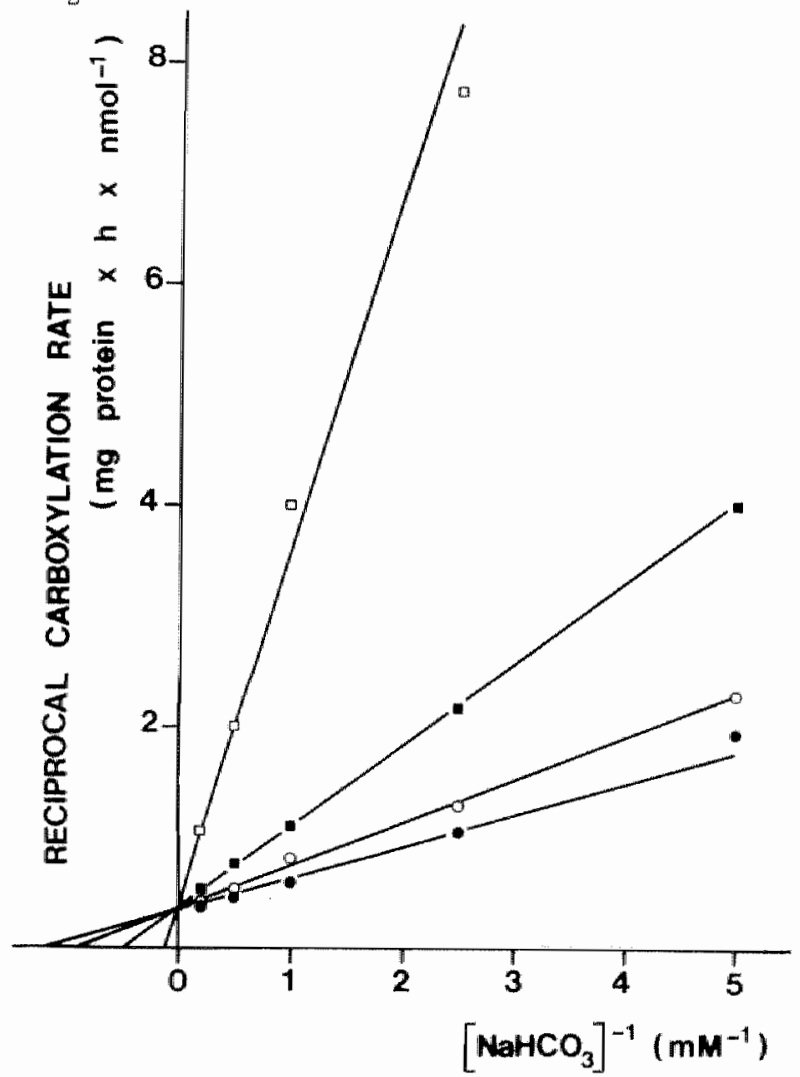

The rate of $\mathrm{CO}_{2}$ incorporation at a number of $\mathrm{NaH}^{14} \mathrm{CO}_{3}$ concentrations was masured in the absence of $\mathrm{NaCN}(-0)$, at $0.25 \mathrm{mg} \mathrm{NaCN}(0-0), 1 \mathrm{~mm} \mathrm{NaCH}$ and $2 \mathrm{~m}$ Nack $(\mathrm{D} \longrightarrow \mathrm{C}$ ). 
Mo competition was observed with one of the other reaction components.

As $\mathrm{CO}_{2}$ is the material, incorporated in the vitamin $\mathrm{K}$-dependent reaction, it might be that after adding NaCN, the inhibitor was incorporated into glutamic acid residues. Therefore we compared the incorporation of ${ }^{14} \mathrm{CN}^{-}$and ${ }^{14} \mathrm{CO}_{2}$ by vitamin $K$-dependent $\mathrm{Sp}$-carboxylase. Although ${ }^{14} \mathrm{CO}_{2}$ was incorporated with a rate of 250,000 dpm per h per ing protein, the incorparation of ${ }^{14} \mathrm{CH}^{-}$could not be demonstrated.

The vitamin ${ }^{2}$-dependent carboxylation of glutamic acid residues and the epoxidation of vitamin $k$ hydroquinone are two clasely associated functions. Hence we also studied the influence of cyanide on the epoxidation reaction (table 1). In order to inhibit trace amounts of reductase, which might be present in the system, we added $100 \mu$ M warfarin to these reaction mixtures. Whereas the carboxylation is completely blocked at $5 \mathrm{mM}$ NaCN, no inhibition of epoxide formation was observed even at a MaCM concentration of $20 \mathrm{~m}$. This clearly demonstrated, that the formation of vitamin $k$ epoxide is not necessarily coupled to the carboxylation reaction.

Table 1. The effect of NaCN on the vitamin K-dependent carboaytation and the vitamin $K$-dependent epoxidation.

The vitumin k-dependent incorporation of ${ }^{14} \mathrm{CO}_{2}$ and the formation of vitamin $k$ opoxide were measured in standard reaction mixtures (1 ml), containing $100 \mu$ warfarin. After incubation for 90 min at $25 \quad 0,0.4 \mathrm{ml}$. was used for determining the amount of incorporated $\mathrm{CO}_{2}$ and $0.4 \mathrm{ml}$ was taken for assesing the amount of epoxide.

\begin{tabular}{lll}
\hline $\begin{array}{l}\text { Nach concentration } \\
(\mathrm{m} M)\end{array}$ & $\begin{array}{l}{ }^{14} \mathrm{CO}_{2} \text { incorporation } \\
\text { (nmol per mg per h) }\end{array}$ & $\begin{array}{l}\text { vitanin } \mathrm{K} \text { epoxide generation } \\
\text { (nrmol per mg per h) }\end{array}$ \\
\hline 0 & 2.5 & 46 \\
2 & 0.4 & 48 \\
20 & 0 & 53 \\
\hline
\end{tabular}

The inhibition of carboxylase by NaCN might be explained by the binding of $\mathrm{CN}^{-}$to a functional haem group. Therefore we resolubilized carboxylase from the solid phase with the aid of $6 \mathrm{M}$ urea and $2 \%$ sodium dodecyl sulphate. Whereas under similar conditions haem could be detected 
(as measured by the optical density at $415 \mathrm{~nm}$ ) in crude microsomes (2.5 nmol per ing protein), we could not detect haem in our purified preparation, which indicates, that the amount of haem in carboxylase is less than 0.05 nmol per of mg protein.

\section{DISCUSSION}

The inhibition of vitamin K-dependent carboxylase by cyanide was found to be competitive with $\mathrm{CO}_{2}$. It is not probable, that cyanide and $\mathrm{CO}_{2}$ have the same or partially the same binding sites, however. In the first place, the non-linearity of the inhibition by cyanide indicates, that more than one binding site for cyanide exists on carboxylase, and that there is a cooperativity in the cyanide binding by carboxylase. On the other hand, we do not have any indication for more than one binding site for $\mathrm{CO}_{2}$. Second$7 y$, the electrophilic $\mathrm{CO}_{2}$ is chemically very different from the nucleophilic $\mathrm{CM}^{-}$. In this perspective it is not surprising that we did not find a vitamin $\mathrm{K}$-dependent incorporation of $\mathrm{CN}^{-}$.

A possible involvement of haem-iron is not substantiated by the observed type of cyanide inhibition, since in that case the inhibition would not be competitive with $\mathrm{CO}_{2}$ but rather with more reducing agents 1 ike vitamin $k$ hydroquinone. A second argument for the non-involvement of haem is that haem does not co-purify with carboxylase, but is removed for more than $98 \%$ from Sp-carboxylase as compared to the crude microsomal solution.

A hydroperoxide intermediate of vitamin $K$ has been postulated as the coenzyme, required for the carboxylation event (13), and it has been shown that also t-butylhydroperoxide supports the carboxylation reaction, even in the absence of vitamin $k(13,14)$. We abserved, that the t-butylhydroperoxide-driven carbaxylase co-purifies with the vitamin $K$-dependent enzyme and that both activities are blocked by NaCN. This supports the hypothesis that both, the t-butylhydroperoxide-driven carboxylation and the vitamin $K$-dependent carboxylation are accomplished by the same enzyme.

It has been postulated by several authors, that the vitamin $k$-dependent carboxylation is coupled to the epoxidation of vitamin $K$ hydroquinone. Carboxylation without epoxidation has never been demonstrated, and inhibitors of the epoxidation reaction (e.g. Chloro-k and peroxidases) also 
intibtt the carboxylation reaction $(7,15)$. On the other hand, the epoxidatfon event seems not necessarily to be coupled to the carboxylation event because, on a molar baslis, the amount of epoxide formed always exceeds the amount of incorporated $\mathrm{CO}_{2}$ (3). Moreover, epoxidation has even been demonstrated in the absence of $\mathrm{CO}_{2}(15)$. This uncoupling of the two reactions is al so 111 ustrated by the fact that cyanide blocks the carboxylation reaction without a simultaneous inhibition of the epoxide formation. Cyanide might therefore be helpful when the epoxidation event has to be studied in the absence of carboxylation. The question whether epoxidation and carboxylation are both catalyzed by the same enzyme remains to be answered, however.

\section{REFERENCES}

1. Johnson, R.C. (1980) Methods Enzymol. 67, 165-180

2. Gallop, P.M., Lian, J.B. and Hauschka, P.V. (1980) New Engl. J. Med. $302,1460-1466$

3. Suttie, J.W. (1980) C.R.C. Crit. Rev. Biochem. 8, 191-223

4. Suttie, J.W., Geweke, L.O., Martin, S.L. and Willingham, A.K. (1980) FEBS Lett. 109, 267-270

5. Hall, A.L., Bettger, W.J. and 01son, R.E. (1981) Fed. Proc. 40, 3650

6. Larsen, A.E., McTigue, J.J. and Suttie, J.W. (1980) in: Vitamin K metabalism and vitamin $k$ dependent proteins (J.W. Suttie ed.) pp 413-421, University Park Press, Baltimore, M.D.

7. Suttie, J.W., Larson, A.E., Canfield, L.M. and Carlisle, T.L. (1978) Fed. Proc. 37, 2605-2609

8. Larson, A.E., Witlon, D.S. and Suttie, J.W. (1979) Fed. Proc. 38,3410

9. De Metz, M., Vermeer, C., Soute, R.A.M., van Scharrenburg, G.J.M., Slotboom, A.J. and Hemker, H.C. (1981) FEBS Lett. 123, 215-218

10. De Metz, M., Vermeer, C., Soute, R.A.M. and Hemker, H.C. (1981), J. Biol. Chem., 256, 10843-10846

11. Vermeer, C., Soute, B.A.M., de Metz, M. and Hemker, H.C. (1982) Biochim. Biophys. Acta $714,361-365$ 
12. Cleland, W.W. (1970) in: The Enzymes, Voll II, 3rd ed., (P.D. Boyer, ed.), Acadamic Press, New York, pp 1-65

13. Larsan, A.E. and Suttie, J.W. (1978) Proc. MatT. Acad. Sci. USA 75, 5413-5416

14. Esnouf, M.P., Burgess, A.I., Walter, S.J., Green, M.R., Hill, M.A.O. and Okolow-Zubkowska, M.J. (1980) in: Vitamin $K$ metabolism and vitamin $K$ dependent proteins (J.W. Suttie, ed.) pp 422-432, University Park Press, Baltimore, MD

15. Be11, R.G. (1978) Fed. Proc. 37, 2599-2604

16. Sadowski, J.A., Schnoes, H.K. and Suttie, J.W. (1977) Biochemistry 16, $3856-3863$ 

CHAPTER 8

STUDIES ON THE MECHANISM OF THE VITAMIN K-DEPENDENT CARBOXYLATION REACTION; CARBOXYLATION WITHOUT THE CONCURRENT FORMATION OF VITAMIN $K$ 2,3-EPOXIDE.

This work is accepted for publication, M. de Metz, B.A.M. Soute, H.C Hemker, R. Fokkens, J. Lugtenburg and C. Vermeer, J. Biol. Chem. 
In addition to the three krown forms of vitamin $k$ (vitamin $k$ quinone, $v$ ftamin $k$ hydroquinone and vitamin $k$ epoxidel, a fourth metabolite, hydroxywtamin $K$, was found in reaction mixtures containing a vitamin k-dependent carboxylating enzyme system. When sulphite was added to such reaction mixtures, the formation of hydroxyvitamin $K$ was substantially enhanced, whereas no epoxide was formed anymore. The vitamin $k$-dependent carboxylation was stimulated at these sulphite concentrations. Vitamin $K$ hydroquinone could be replaced by t-butylhydroperoxide and al so under these conditions the carboxylation was enhanced by sulphite. In the presence of peroxidase the carboxylation reaction was blocked, whereas hydroxyvitamin $k$ could sti1l be detected in the reaction mixtures, even in the absence of sulphite. These observations lead us to the hypothesis, that the carboxylation of glutamic acid residues is coupled to the heterolytic cleavage of a: peroxyde bond with the concurrent formation of vitamin epoxide.

\section{INTRODUCTION}

Vitamin $K$-dependent carboxylase has been obtained from various tissues and from a number of species (1-4). The only carboxylating enzyme system that could be purified to a reasomable extent, is bovine liver carboxylase $(5,6)$. The purification occurs with the aid of antibodies to blood clotting factor $x$, which are cross-linked to sepharose. The antibadies are able to extract complexes of a factor $x$-precursor and carboxylase from a crude detergent-solubilized microsomal preparation. The solid-phase carboxylase whus fomed (Sp-carboxylase) was analyzed and it could be demonstrated, that the enzyme is constituted of $30 \%(w / w)$ phosphatidylcholine and $70 \%$ (w/w) proteins (chapter 6). In this chapter we describe a) the extraction and analysis of vitamin $k$ from sp-carboxylase during the carboxylation reaction and b) the detection of a number of intermediate forms to which witamin $k$ is converted duming this reaction. 
Materials. Triton $X-100$, vitamin $k_{1}$, warfarin, horsemradish peroxidase and dithiothreitol were obtained from Sigma, $\mathrm{NaH}^{14} \mathrm{CO}_{3}(40 \mathrm{mCi} / \mathrm{mmol})$ and Aquasol-2 from New England Nuclear. ${ }^{3} H$-labeled vitamin $K_{1}$ was a kind gift of Hoffmann-La Roche. The synthetic pentapeptide Phe-Leu-Glu-Glu-Leu was purchased from Vega Fox. All other chemicals were from Merck. Vitamin $k$ epoxide and vitamin $K$ hydroquinone were prepared as described earlier (8)

Methods. Solid phase carboxylase ( $5 p$-carbaxylase) was prepared from the livers of warfarin-treated cows (chapter 4, 6) The incorporation of ${ }^{14} \mathrm{CO}_{2}$ was measured as described by de Metz et a7. (chapter 5, 7). In order to inhibit traces of reductase, which might be present in Sp-carboxylase, we added $20 \mu M$ warfarin to all reaction mixtures. All data are given as the sum of the carboxylation of the endogenous and exogenous substrate.

The various forms of vitamin $k$ were extracted from carboxylating reaction mixtures ( $1 \mathrm{ml}$ ) by adding $10 \mathrm{ml}$ hexane and $15 \mathrm{ml}$ isopropanol, followed by shaking the mixtures for $5 \mathrm{~min}$. Subsequently $5 \mathrm{ml}$ water was added and the lower phase was discarded. The solvent of the upper phase was evaporated on a rotavapor and the remaining vitamin $k$ metabolites were dissolved in $0.2 \mathrm{ml}$ methanol and analyzed by means of high perfarmance liquid chromatography on a Spectraphysics SP 8000 liquid chromatograph, using a CP Spher $C 18$ column (Chrompack, $25 \times 0.46 \mathrm{~cm}$ ) in methanol. The flow rate was $2 \mathrm{ml}$ per min and the effluent was monitored at $254 \mathrm{~nm}$. The various forms of vitamin $K$ were well separated and the area under each peak was recorded automatically and corrected for the relative absorbance at the detection wavelength, using ${ }^{3} \mathrm{H}$-labeled vitamin $\mathrm{K}$ as a standard.

Field desorption mass spectra (9) of samples from the varlous peaks were taken using a Varian Mat 711 double focusing mass spectrometer with a combined electron impact/field ionization/field desorption ion source and coupled to a spectro system MAT 100 data acquisition unit. $10 \mu \mathrm{m}$-tungsten wire FD emitters containing carbon microneedles with an average length of $30 \mu \mathrm{m}$ were used. The samples were dissolved in methanol and loaded anto the emitters with the dipping technique. The ion source was $30^{\circ} \mathrm{C}$. During the high resolution field desorption mass spectroscopy measurements, a resolving power of 9000 (10\% valley definition) was used. 
Polyacrylamide gel electrophoresis in the presence of sodium dodecyl sulphate was performed according to Laemml 1 (10) and protein concentrations were determined as described by Lowry and coworkers (11). $\mathrm{CO}_{2}$ concentrations in the reaction mixtures were assessed as described by Rose (12)

RESULTS

Carboxylating reaction mixtures, containing $\mathrm{Sp}$-carboxylase and vitamin $K$ hydroquinone, were incubated and after $5 \mathrm{~h}$ vitamin $K$ was extracted with isopropanol/hexane and analyzed by high performance liquid chromatography $(f i g 1 A)$.

Eig. 1. The detection of various vitamin K metabolites.

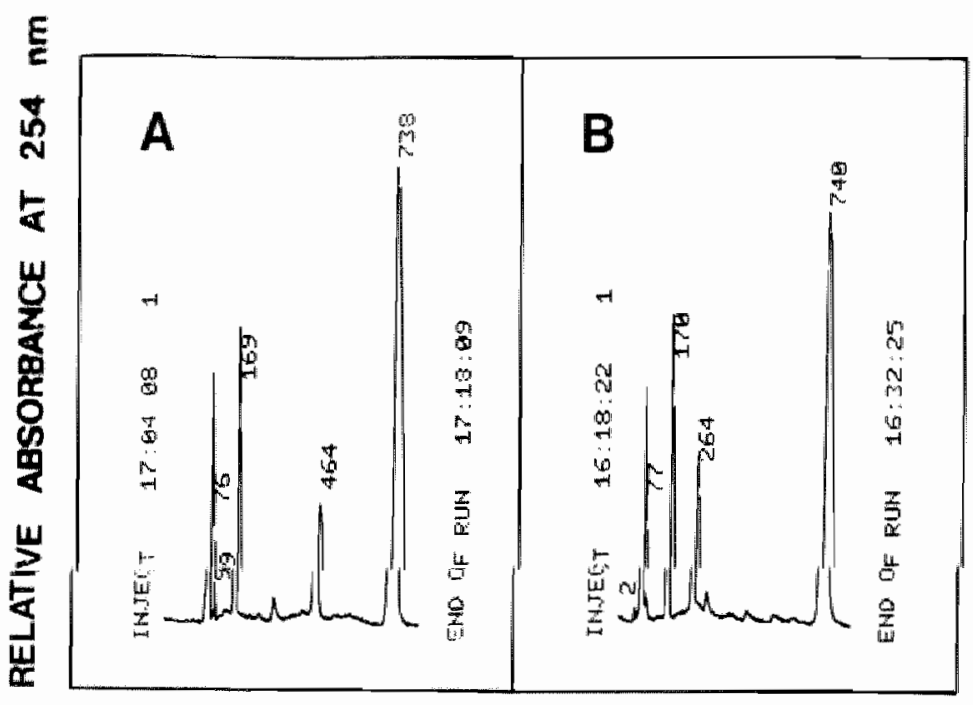

TIME AFTER INJECTION ( $s$ )

A: separation profile of vitamin $K$ metabolites after extraction of a carboxylating reaction mitixture (containing 2 m Phe-Lew-Glu-Qnu-Leu), which had been incubated for $5 \mathrm{~h}$. The peaks eluting after 169,464 and 738 s represent vitamin $k$ hydroquinone, vitamn opoxide and vitamin $\mathrm{K}$, respectively.

B: separtution profile of vitamin $K$ metabolites after extraction of a similar carboxy'lating reaction mixture which had been incubated for $5 \mathrm{~h}$ in the presence of $60 \mathrm{mu}$ $\mathrm{Na}_{2} \mathrm{SO}_{3}$. The peak eluting after 264 s represents hyoroxyvitamin $\mathrm{K}$. 
In the purified system the carboxylation reaction proceeds with the simultaneous formation of vitamin $k$ epoxide, in the same way as in the crude microsomal system. The high peak of normal vitamin $k$ was the result of a rapid non-enzymatic oxidation of vitamin $K$ hydroquinone.

When we added sulphite (a disodium sulphite solution, adjusted to pH 7.4 with $1 \mathrm{M} \mathrm{HCl}$ ) to similar reaction mixtures as described above, the carboxylation reaction was stimulated 1.5 fold, whereas no vitamin $k$ epoxide was formed anymore. Instead of the epoxide, a new peak was monitored (fig 1B), collected and analyzed by mass spectrometry. It resulted, that the newly formed peak was a hydroxylated vitamin $k$.

The observed molecular mass was 468.3605 , which is close to the calcullated value (468.3603). The same results were obtained when benzenesulphinate was used in stead of sulphite. Moreover, when the number of carboxylation events was reduced by omitting the pentapeptide, the formation of hydro-

Fig. 2. Time course of the formation of vitamin $K$ epoxide, hydroxyvitanin $\mathrm{K}$ and the ${ }^{14} \mathrm{CO}_{2}$ incorporation.

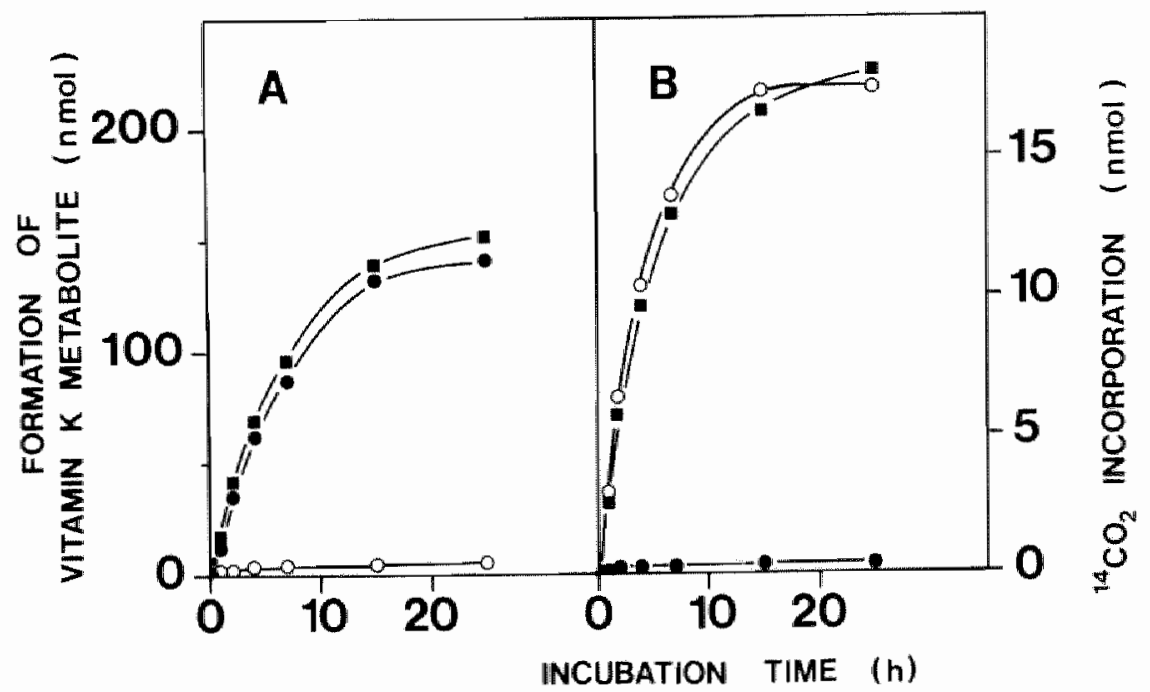

Time course of the formation of vitamin $K$ epoxide (- - ) , nydroxyitamin $K($ $\mathrm{O} \longrightarrow$ ) and the $1 \mathrm{CO}_{2}$ incorporation ( The latter is given as the sum of the carboxylation of the endogenous and exogenous abstrate. A: in the absence of sulpite, $B$ : in the presence of $60 \mathrm{~mm}$ disodium sulphite. 
xylated vitamin $k$ was reduced proportionally. control experiments showed, that hydroxylated vitamin $K$ could not be generated from vitamin $k$ epoxide under the experimental conditions. The time-course of the fomation of hydroxyvitamin $K$ was similar to that of witamin $k$ epoxide (fig 2 ). When calculated on a molar base, the rate of formation of both forms of vitamin $K$ was 10 fold higher than the rate of $\mathrm{CO}_{2}$ incorporation.

When we added horse-radish peroxidase or Fe (instead of sulphite) to carboxylating reaction mixtures, we obserwed that allso in this case the formation of vitamin $k$ epoxide was blocked and again hydroxyvitamin $K$ could be detected in the reaction mixtures (table 1). The main difference between the influence of sulphite and that of peroxidase (or $\mathrm{Fe}^{\text {t+ }}$ ) was that the carboxylation reaction was stimulated by sulphite, but that it was strongly inhibited by peroxidase.

Table 1. The effect of peroxidase and $\mathrm{Fe}^{+*}$ on Sp-carboxyzase mediated reactiona.

\begin{tabular}{|c|c|c|c|}
\hline Enzynes added & $\begin{array}{l}\text { Pormation of } \\
\text { vitamin } K \\
\text { epoxide }\end{array}$ & $\begin{array}{l}\text { formation of } \\
\text { hydroxy- } \\
\text { vitamin } \mathrm{k}\end{array}$ & $\mathrm{CO}_{2}$ uncorporation \\
\hline None & 1 & 0.5 & $a$ \\
\hline Sp-carboxylase $(80 \mu g)$ & 35 & 1.5 & 2.8 \\
\hline $\begin{array}{l}\text { Sp-carboxylase }(80 \mu g) \text { and } \\
\text { peroxidase }(10 \mu g)\end{array}$ & 1 & 8 & 0.06 \\
\hline $\begin{array}{l}\text { Sp-carboxy lase }(80 \mu \mathrm{H}) \text { and } \\
\mathrm{Fe}^{++}(0.1 \mathrm{mM})\end{array}$ & 0 & 4 & 0 \\
\hline Peroxidase $(10 \mathrm{\mu g})$ & 0 & 3.5 & 0 \\
\hline
\end{tabular}

Reaction mixtures ( $1 \mathrm{mil}$ ) containdng $2 \mathrm{mM}$ dithiothreitol, $0.1 \mathrm{~m}$ vitamin $\mathrm{K}$ hydroquinore $2 \mathrm{~min}$ Phe-Lu-alu-Glu-Leu, $1 \mathrm{~m} \mathrm{NaH}^{14} \mathrm{Co}_{3}, 1 \mathrm{~m}$ phenol and enzwres as indicated were inoubated and anelyzed as described in the text. When Fe"t was added, EDTA was omitted fron the reaction mixture. Control experiments in which peroxidase was inactivated, either by onitting phenol or by adding 50 min sodiunazide gave similar results as in the absenee of peroxidese. The enount of incorporated $\mathrm{CO}_{2}$ was calculated after determining the concentrations of labeled (1 m) and unlabeled (1.2 mM) $\infty_{2}$ in the reaction mixtures. All data are expressed as nol per mg carboxylase per $h$. 
We concluded therefore, that the hydroxyvitamin $k$ was formed from a vitamin $K$ peraxide and that this peroxide is destroyed by peroxidase or $\mathrm{Fe}^{+4}$ before it can participate in the carboxylation reaction. On the other hand, the reduction of the peroxide by sulphite seems to occur duming the carboxylation reaction in such a way, that this reaction is even slightly stimulated. The difference between the effect of sulphite and that of peroxidase became even more evident in control experiments, in which Spcarboxylase was onitted. Whereas the formation of hydroxywitamin $k$ by sulphite was strictly dependent on the presence of carboxylase, the peroxidase-catalyzed reaction also proceeded in the absence of carboxylase. The latter observation strongly suggests, that the formation of vitamin $k$ peroxides occurs spontaneously under normal incubation conditions.

In arder to make sure, that the cleavage of the peroxide bond is the step, required for the carboxylation reaction, we replaced vitamin $k$ hydroquinone by t-butylhydroperoxide. The latter is known to stimulate carboxylase in the crude microsomal system from rat liver (13). It resulted that like vitamin $k$ hydroquinone, $t$-butylhydroperoxide is able to serve as

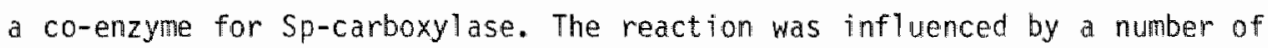
inhibitors and stimulating agents in a similar way as was the vitamin $\mathrm{K}$-dependent reaction (chapter 5, chapter 7) and after acid hydrolysis (24 h) of the reaction product the incorporated label was reduced by $50 \%$. Also in the t-butylhydroperoxide-driven reaction sulphite stimulates the carbox$y$ lation (about 3 fold). So it seems that sulphite is directly involved in the cleavage of the peroxide bond and that the formation of an epoxide is not an absolute requirement for carboxylase activity.

\section{DISCUSSION}

During the last few years a number of authors have speculated about. the possiblity that the formation of vitamin $K$ epoxide was coupled to the vitamin $K$-dependent carboxylation reaction (14). Because it appeared to be very difficult to purify carboxylase to homogenity, it could not be demonstrated unequivocally, that both activities were due to the same enzyme. Until now, Sp-carboxylase is the most purified enzyme system, described in the literature, in which the vitamin $k$-dependent carboxylation reaction can 
take place. Since even in this purified system the incorporation of $\mathrm{CO}_{2}$ always occurred with the simultaneous production of vitamin $k$ epoxide, we assume that both, the carboxylated glutamic acid residues and the vitamin $k$ epoxide are the products of the same reaction. Any reaction mechanism that is proposed should therefore explain the formation of both reaction products.

Because peroxidase strongly inhibits the carboxylation reaction, it seems plausible, that the formation of a vitamin $k$ peraxide precedes this carboxylation reaction. This hypothesis was formulated for the first time by Larson and Suttie (15), who suggested the formation of vitamin $K$ hydroperoxide. The formation of such a hydroperoxide is plausible because naphtoquinones are known to readily form radicals. Once the unpaired electron has been generated, it may migrate through the conjugated ring system and initiate the oxidation of a double bond. We could demonstrate the formation of hydroxyvitamin $k$ by the action of peroxidase, which is compatable with this theory, because the hydroxyvitamin $k$ may be formed from vitamin $k$ hydroperoxide. This would imply that the hydroxyl group is located at the 2 or at the 3 position.

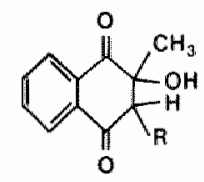

2 -hydroxyvitamin $\mathrm{K}$

With the techniques used in these experiments we were not able to distinguish between 2-hydroxyvitamin $K$ and 3-hydroxyvitamin $K$. Further studies by which we can discriminate between these two forms are in current progress. Since hydroxyvitamin $k$ was also formed by peroxidase in the absence of carboxylase, the latter is thus not necessarily involved in the formation of the hydroperoxide. Therefore vitanin $k$ hydroperoxide may be regarded as the real coenzyme for carboxylase. Since in general hydroquinones rapidly form radicals, and since radical scavengers are inhibitors of carboxylase (16), it seems that the hydroperoxide is formed according to equation 1 . 


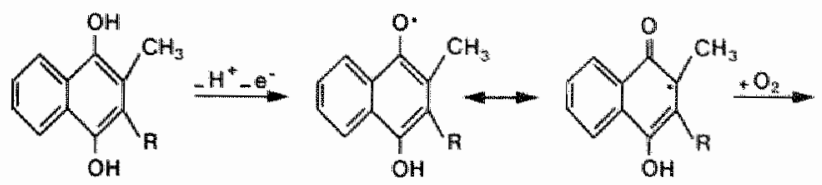

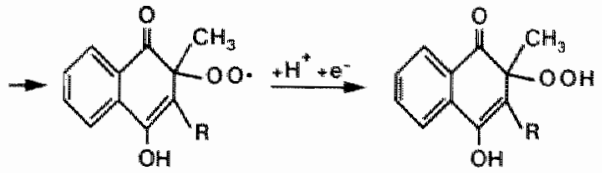

We do not think, that the hydroperoxyde is formed via oxygen radicals ( $\mathrm{OH}$, singlet $\mathrm{O}_{2}$ or $\mathrm{O}_{2}{ }^{-}$), because we have never been able to demonstrate any inhibition of carboxylase by inhibitors of these forms of oxygen (chapter 5). Similar results were obtained by Larson (16) who did not find any stimulation of the carboxylation reaction by these oxygen radicals, moreover.

The role of carboxylase may be that it couples the cleavage of the peroxide bond to the carboxylation of a glutamic acid residue. In the absence of sulphite, the products of this reaction are vitamin $k$ epoxide and a gamancarboxy glutamic acid residue. We propose, that the removal of a gamma hydrogen atom from the glutamic acid residue and the addition of carbon dioxide occur in a concerted reaction (equation 2).

\section{(equation 2)}

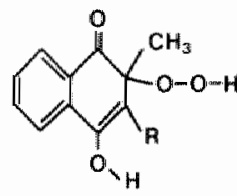

$\frac{{ }^{\mathrm{H}^{\prime} \mathrm{C}^{\prime} \mathrm{CO}^{\prime \prime}} \mathrm{COO}^{-}}{\mathrm{CO}_{2}}$<smiles>[2H]C1=C(O)c2ccccc2C(=O)C1(C)OOCO</smiles><smiles>[2H][C@H](C)C(=O)[O-]</smiles><smiles>CC12COC(=O)C1(C)C(=O)c1ccccc1C2=O</smiles>

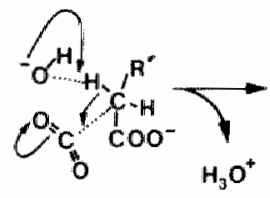<smiles>[2H]C1(O)C(=O)c2ccccc2C(=O)C1(C)OCC(=O)[O-]</smiles> 
This inplies that the peroxide bond is cleaved in a heterolytic way giving rise to a positive charge on the vitamin k-bound axygem and ott. The enzyme-bound of may then be used to remove a gamm-hydrogen atom from the glutamic acid residue and the resulting carbanion will react with $\mathrm{CO}_{2}$. When sulphite is present in the reaction mixture, it might weaken the peroxide bond by its reducing character thus stimulating the electron shift and the carboxyl-ation reaction. At the same time the witamin k-bound oxygen is reduced via a two-electron transfor (sulphite is a two-electron donor) and subsequently protonated to hydroxywitamin $k$.

Alternatively, hydroxyvitamin $k$ might also be formed by an interaction of sulphite with vitamin $k$ epoxide. The stimulation of the carboxylation reaction would then be explained by a rapid consumption of one of the reaction products (vitamin $K$ epoxide) by sulphite. This possiblility is less likely, because a) we have never been able to demonstrate the formation of hydroxyvitamin $k$ from vitamin $k$ epoxide and sulphite and $b$ ) in the $t$-butylhydroperoxide-driven reaction no epoxide can be formed and yet sulphite stimulates this reaction to a similar extent as it stimulates the vitamin $k$ hydroquinome-driven reaction. The mechanism of the t-butylhydroperoxide-driven reaction may also start with the heterolytic cleavage of the peroxide bond. The remaining positively charged t-butyloxide will then either be reduced by the dithiothreitol present in the reaction mixture, or it will undergo a methyl shift and a subsequent hydrolysis to acetone and methanol.

Since on a molar basis more vitamin $k$ epoxide and hydroxyvitamin $k$ are formed than carbon dioxide is incorporated, we assume that the epoxide formation does not always lead to carboxylation. This is in agreement with experiments of Friedman (17), who demonstrated an exchange of 3 H-labeled gamna hydrogen atoms. This exchange was vitamin K-dependent and occurred with a 10 times higher reaction rate than the incorporation of $\mathrm{CO}_{2}$. We suggest, that in the uncoupled reaction a proton takes the place of $\mathrm{CO}_{2}$, thus giving rise to the exchange of the gamma hydrogen with water and the formation of witamin $k$ apoxide.

Acknowledgnent

The authors want to thank prof. dr. N.M.M. Nibbering (head of the mass spectroscopy group of the Laboratary of Organic Chemistry, University of Amsterdan) for his suggestions and critical discussions about our work. 
1. Suttie, J.W., Lehrman, S.R., Geweke, L.0., Hageman, J.M. and Rich, 0.H. (1979) Biochem. Biophys. Res. Comm. 86, 500-507

2. Be11, R.G. (1980) Arch. Biochem. Biophys. 203, 58-64

3. Hauschka, P.V., Friedman, P.A. Traverso, H.P. and Gallop, P.M. (1976) Biochem. Bïophys. Res. Comm. 71, 1207-1213

4. Lian, J.B. and Friedman, P.A. (1978) 253, 6623-6626

5. Canfield, L.M. Sinsky, T.A. and Suttie, J.W. (1980) Arch. Biochem. Biophys. 202, 515-524

6. De Metz, M., Vermeer, C., Soute, B.A.M. and Hemker, M.C. (1981) FEBS Lett. 123, 215-218

7. De Metz, M., Vermeer, C., Soute, R.A.M. and Hemker, H.C. (1981) J. Biol. Chem. 256, 10843-10846

8. De Metz, M., Vermeer, C., Soute, B.A.M. and Hemker, H.C. (1980) in: Vitamin $K$ metabolism and vitamin $K$ dependent proteins (Suttie, J.W. e.d.), pp. 560-570, University Park Press, Baltimore

9. Schulten, H.R. (1979) Intern.J.Mass Spectrom. Ion.Phys. 32, 97-283

10. Laemmli, U.K. (1970) Nature 227 , 680-685

11. Lowry, 0.H., Rosebrough, N.J., Farr, A.L. and Randa11, R.J. (1951) J. Biol. Chem. 193, 265-275

12. Rose, J.G. (1976) Anal. Biochem. 76, 358-360

13. Suttie, J.W., Larson, A.E., Canfield, L.M. and Carlisle, T.L. (1978) Fed. Proc. 37, 2605-2609

14. Suttie, J.W., Geweke, L.0., Martin, S.L. and Wi11ingham, A.K. (1980) FEBS Lett. 109, 267-270

15. Larson, A.E. and Suttie, J.W. (1978) Proc. Nat1. Acad. Sci. USA 75, $5413-5416$

16. Larson, A.E., McTigue, J.J. and Suttie, J.W. (1980) in: Vitamin K metabolism and vitamin $K$ dependent proteins, (Suttie, s.W., ed.) pp.413421. University Park Press, Baltimore,

17. Friedman, P.A. (1980) in Vitamin $K$ metabolism and vitamin $k$ dependent proteins, (Suttie,J.W., ed.) pp.401-407, University Park Press, Baltimore 

CONCLUSTONS AMD SUMMARY

Vitamin $k$ is involved in the carboxylation of a great number of proteins (amongst which four coagulation factors). By this reaction sone of the glutamic acid residues in the polypeptide chain are converted into $\gamma$-carboxyglutamic acid residues. In this thesis we describe some characteristics of the vitamin $k$-dependent carboxylation reaction in cow liver.

When cows are fed with vitanin k-antagonists, the vitamin $k$-dependent reactions are blocked, which results in the appearance of descarboxyfactors in the blood and in an accumulation (50-100 fold) of cloting factor precursors in the liver (chapter 2 and 4). In our in vituro system these precursors serve as an endogenous substrate for carboxylase and they mainly consist of precursors of factor $X(60 \%)$ and prothrombin (25\%). The hepatic factor $x$ precursor is a single chain protein. Since plasma factor $x$ is a two-chain molecule, this observation strongly suggests, that factor $x$ is synthesized as a single polypeptide chain, which is cleaved during the last. stage of its maturation. The almost complete identification of the reaction products of carboxylase could only be obtained in the bovine system. In rat: carboxylase for instance, on $1 y 25 \%$ of the endogenous substrate was identified (1).

In chapter 3 we have shown that descarboxyprothrombin and descarboxyfactor $x$, purified from blood, hardly affect the in vitro carboxylation reaction at plasma concentrations. It could be established that descarboxyprothrombin pmecursors are substrate molecules albeit with a high $\mathrm{k}^{*} \mathrm{~A}^{\mathrm{k}}$ proteolytic degradation product of descarboxyprothrombin (the amino actas $13-29)$ was a far better substrate than the intact molecule. The $k_{m}$ for carboxylase was lowered at least 1000 fold after degradation with subtilisin. The minimal requirement for a good substrate has not been established and it is unknown which other descarboxyfactors contain the intrinsic information to be a good substrate for the carboxylase preparation used. It is not unlikely, however, that at least the clotting factor $x$ and prothrombin are carboxylated by the same enzyme since carboxylase purified with the aid of immunoadsorption to antifactor $x$, is 
still active in the carboxylation of descarboxyprothrombin and its degradation products. The specificity of carboxylase preparations from vartous argans is a subject of current studies.

The development of low molecular weight substrates for the vitamin $k$-dependent carboxylase $(2,3)$ has rendered the possibility to study the carboxylation reaction without being dependent on the presence of endogenous substrates. With one of the substrates (Phe-Leu-Glu-Glu-Leu) it could be demonstrated that warfarin treatment of cows does not affect the level and the properties of hepatic vitamin $K_{\text {-dependent carboxylase }}$ (chapter 2 ).

When measured in the microsomal fraction, the carboxylation reaction can be driven by vitamin $k$ quinone, witamin $K$ hydroquinone as well as by vitamin $k$ epoxide. The highest carboxylation rate is obtained with vitamin $K$ hydroquinone. Vitamin $K$ hydroquinone is believed to be the form which is driving the carboxylation event $(3,4)$ and this implies that vitamin $k$ is first reduced by vitamin $K$ reductase before entering the carboxylating enzyme system. In the presence of vitamin $K$ hydroquinone carboxylase may function independent of the reductase, when the latter enzyme is blocked by warfarin. Vitamin $k$ epoxide is formed in parallel with the carboxylation reaction and can be reduced by vitamin $K$ epoxide reductase. In our system the reduction of vitamin $K$ epoxide (and vitamin $K$ ) could be uncoupled from the carboxylation by using an enzyme preparation without any substrate for the carboxylase. So both carboxylase and reductase may function independently.

Nevertheless it seems probable that carboxylase and reductase are associated within the microsamal membrane (chapter 2). Furthermore we concluded that an intimate link exists between the endogenous substrate and the enzyme, because the complex is retained on a column on which antibodies against the endogenous substrate are present (chapter 4). Also, we showed (chapter 6) that phospholipid (primarily phosphatidylcholine) is an essential constituent of the vitamin $K$-depedent carboxylase. Therefore we postulate the existance of an enzyme complex of carboxylase, reductase, endogenous substrate (if present) and phospholipid. The phospholipid moiety might function in the transport and/or storage of various forms of vitamin $K$ e.g. vitamin $k$ hydroquinome produced by the reductase.

The carboxylase is a constituent of the rough endoplasmic reticulum 
$(5,6)$, which can be extracted therefrom with a number of detergents. After solubilization a considerable purification could be achieved with immunoadsorption onto antibodies against the endogenous substrate (chapter 4). No other satisfactory purification methods have been published until now. In a number of cases the difficulties with the purification might be explained by a loss of the enzyme activity caused by the separation of phospholipid and proteins in the presence of detergents. At least in the bovine system phospholipids are essential for carboxylase activity (chapter 6).

As has been pointed out in chapter 5 the semi-purified carboxylase, after elution from the solid phase, is a high molecular weight moiety consisting of phospholipid and warious proteins. For further purification carboxylase has to be re-solubilized and until now this has not been achieved without loosing the main part of the enzyme activity. We have no indications that cofactors other than vitamin $K$ (e.g. heme) are involved in the carboxylation reaction (chapter 7 ).

Sp-carboxylase is a useful enzyme preparation for studying the vitamin $k$-dependent carboxylation reaction. Most properties are similar to those of other known carboxylase preparations and the purification procedure is simple. The attachement to the Sepahrose beads is advantageous when a quick washing procedure is needed e.g. after the phospholipase treatment (chapter 6). Sp-carboxylase differs from other preparations in several ways: it is more pure, it does contain a low amount of vitamin K-reductase, the carboxylation rate of Phe-Leu-G1 U-G1u-Leu is linear for a longer period, the carboxylation reaction has a higher optimal temperature and the reaction is inhibited by low detergent concentrations.

It is generally believed that the vitamin $K$-dependent carboxylation reaction is coupled to the epoxidation of vitamin $k$ hydroquinone (see chapter 1). Radicals and a hydroperoxide intermediate might be involved in this epoxide formation. The ided that hydroperoxide vitamin $k$ is involved was substantiated by the peroxidase inhibition and the carboxylation with $t$-butylhydroperoxide present instead of vitamin $k$ hydroquinone $(7)$. The t-butylhydroperoxide driven carboxylation was small however and might be effected by an impurity in the carboxylase preparation (8). With the semi purified Sp-carboxylase we could clearly demonstrate that the properties of the t-butylhydroperoxide driven carboxylation were similar to the properties of the vitamin $K$-dependent carboxylation (chapter 5). 
The epoxidation is not absolutely coupled to the carboxylation (4). In most systems more vitamin $k$ epoxide is formed than $\mathrm{CO}_{2}$ incorporated lon a molar basis). With ch the carboxylation could even be completely blocked without blocking the epoxidation (chapter 7 , ref. 9).

In chapter 8 we showed that carboxyllation can occur without the concurrent formation of vitamin $K$ epoxide. In the presence of sulphite a hydroxyvitamin $k$ was formed instead of the epoxide. We concluded that the hydroxywitamin $K$ (and vitamin $K$ epoxide when no sulphite is present) was formed from a hydroperoxide intermediate after a heterolytic fission of the peroxide bond. A the same time a carbanion is formed which can be carboxylated easily. obviously the proposed mechanism has to be verified in a purified system.

REFERENCES

1. Willingham, A.K., Martin, S.L., Graves, C.B., Graban, G.G. and Munns, T.W. (1980) in Witamin $K$ Metabolism and Vitamin $K$ dependent Proteins, (Suttie, J.W. ed.), University Park Press, Baltimore, 533

2. Houser, R.M., Carey, D.J.., Dus, K.M., Marshall, G.R. and Olson, R.F. (1977) FEBS Lett. 75, 226

3. Suttie, J.W. Lehrman, S.R., Geweke, L. O., Hageman, J.H. and Rich, D.M. (1979) Biochem. Biaphys. Res. Commun. 86, 500

4. Suttie, J.W. (1980) C.R.C. Crit.Rew.Biochem. 8, $19 \mathbb{1}$

5. Helgeland, L. (1977) Biochim.Biophys. Acta 499, 181

6. Carlisle, T.L. and Suttie, J.W. (1980) Biachemistry 1,1161

7. Larson, A.E. and Suttie, J.W. (1978) Proc.Nat1.AG.Sci.U.S.A. 75, 5413

8. Hall,A.L., Turner,P.M., Dunk1e,B.F., Wing, D.A. and 01son,R.E. (1980) in Vitamin $K$ Metabolism and Vitamin $K$ dependent Proteins (Suttie, U.W. ed.), University Park Press, Baltimore, 433

9. Larson, A.E., Friedman, P.A. and Suttie, J.W. (1981) J.Biol.Chem. 256,11032 
Vitamine $k$ is nodig bij de carboxylering van een groot aantal eiwitw ten, waaronder verschillende stollingsfaktoren. Bij deze carboxyleringsreactie worden enkele glutaminezuur (glu) resten angezet in $\gamma$-carboxyglutaminezuur ( $g 1 a)$ resten. Na het toedienen van vitamine $K$ antagonisten (hydroxycoumarinederivaten) zakt het plasma niveau van de vitamine $k$ -afhankelijke stallingsfactoren en neemt de kans op ongewenste stolselvorming af. De orale antistollingstherapie met coumaminederivaten neent dan ook een belangrijke plats in bij de bestrijding en preventie vam thrombose. In dit proefschrift wordt het onderzoek naar de vitamine $K$-afhankelijke carboxylering in runderlever beschreven.

Na het toedienen van vitamine K-antagonisten worden de vitamine k-afhankelijke reacties gerend. Descarboxyfactoren (stollingsfactoren met glu resten in plats van gla resten) verschijnen dan in het bloed en precursors van de stallingsfactoren hopen zich op in de lever lhoofdstuk 2 en 4). In het door ons ontwikkelde in vitro systeem kunnen deze precursors vitamine $K$-afhankelijk gecarboxyleerd worden. In hoofdstuk 4 is aangetoond dat het grootste geddelte van de carboxyleerbare eiwitten uit precursors van factor $X$ (ca. 60\%) en prothrombine (ca. 25\%) bestaat. De factor $X$ precursor uit de lever bleek uit ēen eiwitketen te bestaan, terwijl het factor $x$ uit plasma wit twee eiwitketens bestaat.

In hoofdstuk 3 hebben we aangetoond dat descarboxyprothrombine, gejsoleerd uit runderbloed, substraat is voor de vitamine $k$-afhankelijke carboxylase uit runder- en rattelever. De affiniteit van descarboxyprothrombine voor het carboxylase is echter bijzonder 1 aag $\left(K_{m} 0.3-0.4\right.$ mM). Door proteolyt ische afbraak wan descarboxyprothrombine met subtilisine Carlsberg werd een fragment verkregen met een veel hogere affinitelt voor het carboxylase $\left(K_{\mathrm{n}}=0.001-0.003 \mathrm{mM}\right)$. Het fragment bestond wit de aminozuren 13-29 wan descarboxyprothrombine.

In hoofdstuk 2 wordt de vitamine k-afhankelijke carboxylase uit de lever van nomale en geantistolde koeien vergeleken. Behalve in de hoeveelheid precursors, die substrat zijn voor carboxylase, werd geen verschil gevonden tussen de beide preparaten. Tevens wardt in dit hoofdstuk aangetoond dat de vitamine $k$-afhankelijke carboxylering en de reductie van vitamine $k$ onafhankelijk van elkaar kunnen verlopen; de enzymen die deze 
reaktes katalyseren (carboxylase en reductase) zijn echter wel nauw met elkatr verbondeni.

In hoofdstuk 4 wordt de zuivering van carboxylase uit gesolubilizeerde levemicrosomen beschreven. Wij makten gebruik van het feit dat de factor $X$ precursars, die substraat zijn voor het carboxylase, gecomplexeerd zijn met het carboxylase. Met behulp van immunospecifieke adsorptie aan ant 1 lichamen tegen de factor $x$ precursors werd (uttgaande wan de microsomile fractie) een 100-voudige zuivering verkregen. Dit gedeeltelijk gezuiverde preparaat is gebonden aan Sepharose deeltjes en wordt daarom sp-carboxylase (Solid phase carboxylase) genoend.

Enkele eigenschappen van Sp-carboxylase worden beschreven in hoofdstuk 5 en 6 . De belangrijkste eigenschappen zijn vergelijkbaar met die wan een ongezuiverd preparaat. Het sp-carboxylase bevat nog verschillende eiwitcomponenten, warvan twee vitamine $k$ binden. Voorts bestaat het preparaat voor ca. 30\% wit phospholipiden (voormamelijk phosphatidylcholine). Het preparat kon met behulp van phospholipases of detergentia phospholipiden-vrij gemakt worden. Reconstitutie tot ruim $80 \%$ van de oarspronkelijke activiteit was mogelijk door het toevoegen van micellen, die phosphatidylcholine en cholaat bevatten.

In hoofdstuk 7 wordt de reming van de vitamine $k$-afhankelijke carboxylering door cyanide beschreven. Het bleek een niet-lineaire remming te zijn, competitief met $\mathrm{CO}_{2}$. De epoxidering van vitamine $k$ hydroquinone werd niet geremd door cyanide. De remming door cyanide bleek geen argument voor de deelname van een haem groep aan de vitamine $k$-afhankel ijke carboxyleringsreaktie. Haem kon bovendien niet aangetoond worden in Sp-carboxylase.

In hoofdstuk 8 tenslotte wordt beschreven dat de vitamine $k$ afhankelijke carboxyleringsreaktie gekoppeld is aan de vorming van witamine $k$-epoxide. In aanwezigheid van sulfiet kan de carboxyleringsreaktie echter gekoppeld worden aan de vorming van hydroxy vitamine $k$. De camboxyleringsreaktie werd tevens gestimuleerd in aanwezigheid van sulfiet, zowel de vitamine $K$-afhamkelijke als ook de t-butylhydroperaxide afhankelijke carboxylering. In anwezigheid van peroxidases werd de carboxyleringsreaktie en de vorming van vitamine $k$ epoxide gerend, terwijl hydroxyvitamine $k$ wel gevormd werd (ook in afwezigheid van sulfiet). Deze bevindingen leidden tot de hypothese dat de carboxylering van glutaminezuur resten gekoppeld is aan een heterolytische splitsing van een peroxide binding met de gelijktijdige vorming wan vitamine $k$ epoxide. 

De schrijuer van dit proefschrift werd op 14 juli 1950 te Den Haag geboren. In 1969 behalde hij het diplona gymnasium $B$ aan het Vossius gymasium te Amsterdam en in datzelfde jaar begon hij met de studie scheikunde aan de Universiteit van Amsterdam. Het doctoraal examen met als hoofdvak biochemie werd in 1977 afgelegd. Van juli 1977 tot maart 1978 werkte hij als wetenschappelijk medewerker op het B.C.P.Jansen instituut te Amsterdam. Sinds april 1978 is hij als wetenschappelijk medewerker verbonden aan de capaciteitsgroep Biochemie wan de Rijksuniversiteit Limburg te Maastricht. Bij deze groep werd onder leiding van dr. C.Vermeer en prof. dr. H.C. Hemker het in dit proefschrift beschreven onderzoek verricht. 